\title{
Multidrug Resistance (MDR) and Collateral Sensitivity in Bacteria, with Special Attention to Genetic and Evolutionary Aspects and to the Perspectives of Antimicrobial Peptides-A Review
}

\author{
András Fodor 1,*®i , Birhan Addisie Abate ${ }^{2}$, Péter Deák ${ }^{1,3}{ }^{\circledR}$, László Fodor ${ }^{4}$, Ervin Gyenge ${ }^{5,6}$, \\ Michael G. Klein ${ }^{7}$, Zsuzsanna Koncz ${ }^{8}$, Josephat Muvevi ${ }^{9}$, László Ötvös ${ }^{10,11,12}$, \\ Gyöngyi Székely ${ }^{5,6,13}$, Dávid Vozik ${ }^{14}$ and László Makrai ${ }^{4, *}$ \\ 1 Department of Genetics, University of Szeged, H-6726 Szeged, Hungary; deakp@brc.hu \\ 2 Ethiopian Biotechnology Institute, Agricultural Biotechnology Directorate, Addis Ababa 5954, Ethiopia; \\ birhanaddisie@gmail.com \\ 3 Institute of Biochemistry, Biological Research Centre, H-6726 Szeged, Hungary \\ 4 Department of Microbiology and Infectious Diseases, University of Veterinary Medicine, P.O. Box 22, \\ H-1581 Budapest, Hungary; Fodor.Laszlo@univet.hu \\ 5 Hungarian Department of Biology and Ecology, Faculty of Biology and Geology, Babes-Bolyai University, \\ 5-7 Clinicilor St., 400006 Cluj-Napoca, Romania; gyenge_ervin@yahoo.com (E.G.); \\ gyongyi.szekely@ubbcluj.ro (G.S.) \\ 6 Institute for Research-Development-Innovation in Applied Natural Sciences, Babeș-Bolyai University, \\ 30 Fântânele St., 400294 Cluj-Napoca, Romania \\ 7 Department of Entomology, The Ohio State University, 1680 Madison Ave., Wooster, OH 44691, USA; \\ klein.10@osu.edu \\ 8 Max-Planck Institut für Pflanzenzüchtungsforschung, Carl-von-Linné-Weg 10, D-50829 Köln, Germany; \\ zskoncz@mpipz.mpg.de \\ 9 National Cereals and Produce Board, Mombasa 80100, Kenya; jmuvevi@gmail.com \\ 10 OLPE, LLC, Audubon, PA 19403-1965, USA; lotvos@comcast.net \\ 11 Institute of Medical Microbiology, Semmelweis University, H-1085 Budapest, Hungary \\ 12 Arrevus, Inc., Raleigh, NC 27612, USA \\ 13 Centre for Systems Biology, Biodiversity and Bioresources, Babeș-Bolyai University, 5-7 Clinicilor St., \\ 400006 Cluj-Napoca, Romania \\ 14 Research Institute on Bioengineering, Membrane Technology and Energetics, Faculty of Engineering, \\ University of Veszprem, H-8200 Veszprém, Hungary; vozik.david@drv.hu or \\ vozik.david@mk.uni-pannon.hu or vozikd@gmail.com \\ * Correspondence: fodora@expbio.bio.u-szeged.hu or fodorandras@yahoo.com (A.F.); \\ Makrai.Laszlo@univet.hu (L.M.); Tel.: +36-(30)-490-9294 (A.F.); +36-(30)-271-2513 (L.M.)
}

Received: 23 March 2020; Accepted: 23 June 2020; Published: 29 June 2020

check for updates

\begin{abstract}
Antibiotic poly-resistance (multidrug-, extreme-, and pan-drug resistance) is controlled by adaptive evolution. Darwinian and Lamarckian interpretations of resistance evolution are discussed. Arguments for, and against, pessimistic forecasts on a fatal "post-antibiotic era" are evaluated. In commensal niches, the appearance of a new antibiotic resistance often reduces fitness, but compensatory mutations may counteract this tendency. The appearance of new antibiotic resistance is frequently accompanied by a collateral sensitivity to other resistances. Organisms with an expanding open pan-genome, such as Acinetobacter baumannii, Pseudomonas aeruginosa, and Klebsiella pneumoniae, can withstand an increased number of resistances by exploiting their evolutionary plasticity and disseminating clonally or poly-clonally. Multidrug-resistant pathogen clones can become predominant under antibiotic stress conditions but, under the influence of negative frequency-dependent selection, are prevented from rising to dominance in a population in a commensal niche. Antimicrobial peptides have a great potential to combat multidrug resistance, since antibiotic-resistant bacteria have shown a
\end{abstract}


high frequency of collateral sensitivity to antimicrobial peptides. In addition, the mobility patterns of antibiotic resistance, and antimicrobial peptide resistance, genes are completely different. The integron trade in commensal niches is fortunately limited by the species-specificity of resistance genes. Hence, we theorize that the suggested post-antibiotic era has not yet come, and indeed might never come.

Keywords: MDR; intrinsic/acquired resistance; collateral sensitivity; negative frequency-dependent selection; experimental evolution; pangenome; global dissemination; mobility patterns of resistance genes; adaptive evolution

\section{Introduction}

The rapid and ongoing spread of antibiotic resistance poses a serious threat to global public health [1]. Considering the complexity of the sophisticated resistance mechanisms [2,3], recruiting cooperating scientists with different backgrounds seems reasonable and necessary. This review is addressed to committed scientists, biologists, geneticists, and evolutionary biologists who may be attracted by fundamental, rather than applied, research perspectives. We focused on selected aspects. One is the danger posed by globally spreading monoclonal pathogens (Acinetobacter baumannii [4-6], Pseudomonas aeruginosa [7-9]), with an expanding open pangenome, being aware that they are not the only ones displaying a threat.

Antibiotic resistance was discovered in 1940 [10]. The selective pressure of antimicrobials is favorable for resistant clones to survive and spread [11]. The emergence of antibiotic multiresistance (MDR) in pathogenic bacteria has become alarming in the last decades [12]. MDR appeared not only in human clinical pathogens [13-16] but also in zoonic bacteria [17,18], veterinary pathogens [19-26], and in plant pathogens [27-32]. Although application technologies are improving for plant pathogens [33], the trend has been that the use of antibiotics as plant medicines has gradually been restricted [34, 35]. A precondition for elaborating appropriate therapies is having a better understanding of antibiotic resistance mechanisms [36] in Gram-negative [13,16,37] and Gram-positive [38-41] pathogens. New "bugs" are continuously appearing, and new antibiotics are needed. Conly and Johnson asked in 2005 "Where are the new antibiotics?" [42]. The tantalizing answer came 11 years later: Antibiotics are "right under our nose!" [43]. Unfortunately, they still have not made it to market [44], at least not in the required number $[45,46]$.

\section{Multidrug Resistance: Updated Terms and Definitions}

The genomes of different bacterium species harbor silent genes that code for resistance, but in the absence of antibiotics it is not manifested. Consequently, a large pool of potential of antibiotic resistance genes is hidden in various niches. The term antibiotic resistome covers the collection of all antibiotic resistance genes, including those associated with both pathogenic and non-pathogenic bacteria, but not ones which produce antibiotics [47]. Pál and his associates provided a comprehensive characterization of resistance genes, mobile genetic elements (MGEs), and bacterial taxonomic compositions for 864 metagenomes from humans $(n=350)$, animals $(n=145)$, and external environments $(n=369)$, all deeply sequenced using Illumina technology. They concluded that antibiotic-polluted environments are probably under-estimated transmission routes, and indeed reservoirs for antibiotic resistance [48].

\subsection{Antibiotic Resistance as a Phenotype}

The resistance genotype [49-51] determines the resistance phenotype. Take the evolutionary history of Mycobacterium tuberculosis resistance to second-line anti-tuberculous as a scholarly medical genetic example to illustrate the simple Mendelian genotype-phenotype relations [52-55].

Genetic suppression of the cellular autolytic system of pneumococci causes simultaneous resistance to penicillin, D-cycloserine, and phosphonomycin [56], providing an example of the iso-allelic 
inheritance phenotype [57,58]. Physiological suppression is similar [56], providing an example of the old genetic term, phenocopy $[59,60]$. The clarification of genotypic/phenotypic relations is a prelude to the application of clinical metagenomics [61].

\subsection{The Location and Harboring of the Resistance Genes}

The resistance gene is a peptide-coding open reading frame, genetically regulated as structure gene of an operon. The higher level of organization is the antibiotics resistance cassette [62-64]. The respective resistance gene(s) could be localized either on the chromosome [51], or in a plasmid [65-69], either as non-conjugative [62], conjugative [70,71], or in an episome [72].

\subsection{Insertion and Excision}

The resistance gene as an integron component [71,73] can be harbored by a mobile genetic element capable of inserting into, and excising from, another DNA molecule like a plasmid. This has been reviewed by several authors [74-79].

\subsection{Homolog Recombination}

Some mobile elements are capable of recombining with the bacterial chromosome, allowing transfer of large segments, as shown with vancomycin and penicillin resistance transfer, at least in Gram-positive (Enterococcus) pathogens [80,81]. Horizontal gene transfer (HGT) could happen even between the different bacteria taxa $[82,83]$.

\subsection{Intrinsic Resistance (IR)}

IR is the phenotypic expression of a resistance gene originally present, resulting in structural and functional changes of the original gene product $[84,85]$. This can be either a decomposing enzyme [86-88], or the target site of the drug [89,90]. The most efficient resistance mechanisms are the multidrug efflux pumps [91-94].

When resistance to antimicrobial compound is a phenotypic expression of a resistance-encoding gene coming from outside via horizontal gene transfer HGT [95-100], it is called "acquired" resistance $[85,101]$. The gene from outside had been harbored by a plasmid and was taken up from the environment, such as from soil $[102,103]$ or the gastrointestinal $[83,99]$ microbiota community. Expansion of KPC-producing Klebsiella pneumoniae with various mgrB mutations giving rise to colistin resistance [104], and the bla (VIM-1) metallo-beta-lactamase producing. E. coli was published to spreading over in a university hospital in Greece [105]. These are examples of concerted activities of mobile genetic elements, including insertion sequences, transposons, and gene cassettes/integrons, and has been summarized by Partridge et al. [79]. Horizontal gene transfer (HGT) could even happen between different bacteria taxa [82,83].

The novel phenomenon called distributive conjugal gene transfer (DCT) was recently discovered in mycobacteria. DCT involves the transfer of chromosomal DNA between mycobacteria and, most significantly, generates trans-conjugants with mosaic genomes of the parental strains [106].

\subsection{Definitions of Antibiotic Polyresistant Strains}

Antibiotic resistances [2,3] are classified as follows: multidrug resistant (MDR) is not susceptible to at least one representative from each of three categories of selected antimicrobial compound families [3]. Extreme drug-resistant (XDR) is not susceptible to at least a single representative of all but very few categories of antimicrobial compound families. Pan-drug resistant (PDR) is not susceptible to any of the tested representatives of all known antimicrobial compound families [3]. 


\subsection{The Updated List of the "ESKAPE" Polyresistant Pathogenic Bacterium Species}

In 2006, the Antimicrobial Availability Task Force (AATF) of the Infectious Diseases Society of America (IDSA) prepared a review that highlighted frequently resistant pathogens to licensed antimicrobials [36], characterized by high antibiotic resistance, and extremely versatile MDR phenotypes which are responsible for many nosocomial infections [36]. As for their clinical significance [107], the updated the list of six ESKAPE Pathogen Bacterium Species appeared in 2008 [18]. The six letters are the initials of the genera of these bacteria: Enterococcus faecium, Staphylococcus aureus, Klebsiella pneumoniae, Acinetobacter baumannii, Pseudomonas aeruginosa, and Enterobacter spp. [108-112]. There is "NO DRUG" against them and "NO ESKAPE" from them [109]. They include causative pathogens of nosocomial diseases, such as ventilator-associated pneumonia [113,114], infections in burn wounds [115], and pathogens which "escape" from antimicrobial agents [109,116,117]. Immune-compromised patients are most exposed to ESKAPE pathogens causing bacteremia [118].

The ESKAPE list has recently been updated by the World Health Organization (WHO) [119]. It includes the carbapenem-resistant Klebsiella pneumoniae, Acinetobacter baumannii, Pseudomonas aeruginosa, carbapenem-resistant and third-generation cephalosporin-resistant Enterobacteriaceae, clarithromycin-resistant Helicobacter pylori, fluoroquinolone resistant Campylobacter spp., Neisseria gonorrhea, and Salmonella typhi as community-acquired infection-causing pathogens. The highest-ranked Gram-positive members are vancomycin-resistant Enterococcus fecalis and Ent. faecium, as well as the methicillin-resistant (MRSA) S. aureus [119]. The resistance mechanisms used by the ESCAPE pathogens were recently reviewed [120].

Some other dangerous Gram-negatives such as Escherichia coli, Francisella tularensis, and Grampositives Mycoplasma bovis and Bacillus anthracis may be considered as putative "ESKAPE Club-Members" in the future. We discuss this option in Supplementary Material 1.

\section{Resistance Problems Related to Gram-Negative Pathogens}

The logical chain of events leading to multidrug resistance in Gram-negative pathogens is illustrated in Figure 1. (LEFT).

\subsection{B-Lactams vs. ESBL Resistance in Enterobacteriaceae and Klebsiella pneumoniae}

The $\beta$-lactams were introduced to overcome penicillin resistance by preventing re-assembly of peptidoglycan bonds, which eventually leads to cell lysis [121,122]. Extended-Spectrum B-Lactamase (ESBL) producing Enterobacteriaceae and K. pneumoniae pathogens are resistant to $\beta$-lactam-based antibiotics. The emergence of, and challenges by, ESBL-producing Enterobacteriaceae has been reviewed over the last three decades [123-126]. Pitout suggested that in vitro resistance to ceftazidime, and/or aztreonam, should be used as phenotypic markers of ESBL [127]. In Gram-negative bacteria, the $\beta$-lactamase production is frequently associated with reduced permeability of the outer membrane efflux [128].

Biochemistry has increased the number of $\beta$-lactamase enzymes with enlarged substrate specificities [129]. The substrate range includes cephalosporins (cefotaxime, ceftriaxone [130-132]), monobactam aztreonam [133-135], amino-penicillin combinations [136], lactamase inhibitor ampicillinsulbactam [137-140], ureido-penicillins [141,142] including piperacillin/tazobactam [143-146], temocillin [147], piperacillin/tazobactam [148], and ceftolozane-tazobactam [149]. Furthermore, the appearance of new enzymes is not associated with the loss of ability to hydrolyze the earlier lactams, such as ampicillin [36]. In addition, the prevalence of ESBL production among E. coli and Klebsiella species is variable [13]. ESBL can be considered as first strike back from the Gram-negative pathogens or as the first "Wedge" from Nature. 


\subsection{Carbapenems: A Strong Antibiotic ("High Card") to Beat the "Wedge" ESBL}

To overcome ESBL problems, a new beta-lactam class of antibiotics, the carbapenems [150,151], was developed [152], including blood and respiratory isolates of P. aeruginosa [153]. As Breilh and his associates summarized, they act either as "slow substrate" $\beta$-lactamase inhibitors or by binding to penicillin-binding proteins [154]. This "value-added feature" of inhibiting $\beta$-lactamases serves as a major rationale for the expansion of this class of $\beta$-lactams [155]. Carbapenem antibiotics, including imipenem, are Gram-negative cell-wall synthesis interrupting molecules, which bind to penicillin-binding proteins [156]. Cilastatin is a human enzyme, dehydropeptidase, in the kidney that inhibits imipenem degradation and meropenem [156], as well as ertapenem [157]. Each one alone, or in combination, had been a putative last line of defense against multidrug-resistant Gram-negative organisms.

\subsection{Carbapenem Resistance: The Second Strike Back from the Gram-Negative Pathogens ("Wedge" from Nature)}

Since 2006, the number of carbapenem-resistant Enterobacteriaceae (CRE) has significantly increased [158-160]. A novel, epidemic, serine class-A type enzyme (KPC) is behind carbapenem resistance. It is encoded by the Bla (Oxa) gene family [161-165]. KPC exhibits powerful activity against all types of Beta-lactam molecules [166-168].

\subsection{NDM1}

A novel type of plasmid-encoding carbapenem-resistant metallo- $\beta$-lactamasecarbapenemase NDM 1 [169] was identified in 2008 in two Enterobacteriaceae isolates, both recovered from a Swedish patient transferred from India [170]. The emergence of NDM-expressing enterobacteria [171] and Klebsiella $[172,173]$ was then reported from all continents, but it recently reappeared in Italy (Toscana, Z. Koncz, personal communication). There are publications on NDM 1 expressing Acinetobacter [174], Pseudomonas [175], and only one E. coli publication [105]. It has never been found in Gram-positive bacteria. Klebsiella pneumoniae, Acinetobacter, and Pseudomonas are spread by clonal dissemination [176], while E. coli and other Enterobacteriaceae spread through polyclonal dissemination [177]. Many carbapenem-resistance genes localized on mobile genetic elements have been previously reviewed [178-184].

\section{5. "Dropped and Rediscovered" Colistin, as a Large Spectral Antibiotic (a "Trump Card")}

The cationic lipopeptides polymyxin B, E, and colistin [185] disrupt outer membranes (OMs) and have been used since 1959 for treating infections caused by Gram-negative MDR pathogens. However, nephrotoxic side effects were discovered [186]. Since the appearance of several new infections caused by MDR Gram-negative organisms [187,188], and intensive searches of old antibiotic options, colistin was rediscovered and considered to be a potential trump card [189-194].

\subsection{Colistin Resistance: The Third Unexpected Attack ("Wedge") from Nature}

The first colistin-resistant mutant was reported in 1981 [195]. The appearance of colistin resistance, especially plasmid-mediated transferable ones [196-201], questioned whether the polymyxins should be considered as the last "life-savers" [202]. Colistin resistance is a consequence of post-translational modification, or loss, of the lipopolysaccharide (LPS) molecules [203]. The first colistin-resistant mutant was reported in 1981. The appearance of colistin resistance, especially the plasmid-mediated transferable ones, questioned whether the polymyxins were still be considered as the last "life-savers". The mechanisms of acquired and intrinsic resistance of polymyxin in different bacteria have recently been reviewed by many authors [204-209]. The genetic factors behind colistin resistance are $\mathrm{mcr}$ genes [198,210,211]. Colistin resistance has been evolving under clinical conditions [212,213] in A. baumannii [214-216], P. aeruginosa [217], K. pneumoniae [218,219], and Enterobacter cloacae [220]. 
The evolution of colistin resistance was more than a one step process, requiring mutation in at least five independent loci synergistically, creating the resistant phenotype [211,212,221,222].

3.7. Efforts to Overcome MDR Problems in Gram-Negative Pathogens in the Absence of Omnipotent ("Jolly Joker") Antibiotics

The potentiation of $\beta$-lactam antibiotics and $\beta$-lactam with $\beta$-lactamase inhibitor combinations was effective when used against MDR and XDR P. aeruginosa, using non-ribosomal tobramycincyclam conjugates [223,224]. A detailed evaluation of publications reviewing arguments for and against combining colistin and carbapenems controlling infections caused by carbapenem-resistant Enterobacteriaceae (CRE), K. pneumoniae carbapenemase (KPC)-producing bacteria, and carbapenem-resistant $A$. baumannii (CRAB), based on randomized controlled trials in which treatment with colistin was in combination with meropenem or rifampin, showed it did not work as expected. This demonstrates that the use of some polymyxin has always been necessary when either CRAB, CRE, or CRPA harboring metallo-beta-lactamases are at stake [225]. The combination strategy is especially useful when the applictiin design is syncronized with the results by obtained the recently published cassette assay [226] (aiming efficiently quantifying the outer membrane (OM) permeability of multiple $\beta$-lactams in carbapenem and colistin-resistant Klebsiella. pneumoniae) and enabling to rationally optimize the use of the dose of synergistic $\beta$-lactam antibiotics, [226].

\section{Resistance Problems Related to Gram-Positive Pathogens}

The logical chain of events leading to multidrug resistance in Gram-positive pathogens is illustrated in Figure 1. (RIGHT).

Streptococcus and Enterococcus species are intrinsically resistant to beta-lactams [227]. They use beta-lactamases and/or just [228] penicillin-binding polypeptides [229]. This has been reviewed by Funda and his associates [230].

\subsection{Methicillin-Resistant Staphylococcus aureus (MRSA)}

Since the early sixties [231], multiresistant pathogen strains [232,233], including those resistant to vancomycin, have appeared [234]. MRSA is the causative agent in many diseases worldwide [235]. This includes nosocomial infections like pneumonia [236], spondylodiscitis [237], colonization of burns and wounds [238,239], endocarditis [240], and renal problems [241], all of which have greatly increased hospital death tolls [242]. Methicillin-resistant S. aureus (MRSA), and S. epidermis isolates, from companion animals have been reviewed $[243,244]$. Previously, the clinical use of vancomycin, synergistically combined with antibiotics, was suggested against poly-resistant clinical isolates [245]. However, vancomycin and daptomycin resistance have developed in the same patient within hours [246].

\subsubsection{The Molecular Basis of MRSA}

Extreme methicillin resistance is polygenicly inherited [247]. The responsible chromosomal DNA segment of $\sim 50 \mathrm{~kb}$, named mec, consists of the open-reading frame mecA coding for the penicillin-binding protein 2a (PBP 2a), linked to the regulatory genes mecI and mecR1, which control mecA expression. A variable number of resistance determinants are also included [248]. Strains lacking mecA may show low-level methicillin resistance, due to modifications in native PBPs, or the expression of beta-lactamase [249]. However, there is only one publication on methicillin decomposing an enzyme [250], which has not been confirmed.

\subsubsection{The Accelerated Evolution of MRSA}

MRSA evolution started when the mecA was acquired, probably when the penicillinase-resistant oxazolidines were introduced [251]. The genetic profile, antibiotic resistance and bacteriophage profiles, 
and the pulse-field patterns of contemporary epidemic MRSA clones were very similar to those of the early methicillin-sensitive (MSSA) isolates [252].

The evolutionary history of MRSA was reviewed by Antignac and Tomasz [253]. The donor S. sciuri strain has a mecA-homolog gene, capbpD, coding for the penicillin-binding protein PBP 4 . The mecA gene is harbored by a SCCmec element and was horizontally transferred to an originally sensitive (MSSA) strain of S. aureus [253]. Since this discovery, an international working group (IWG-SCC) has been concentrating on the classification of "Staphylococcal Cassette Chromosome Elements" [254,255]. Another team (Cepheid Healthcare-Associated Infection (HAI) Consortium) has continuously been addressing the changing epidemiology of MRSA isolates, with the recognition of both "empty cassette" strains, where mecA is lost from the SCCmec cassette, and the emergence of SCCmec variants [256]. The first MRSA isolates, followed by applied Bayesian phylogenetic reconstruction, provided an option for reconstructing further details of the evolutionary history of the archetypal MRSA [257]. Harkins and his associates assumed the approximate date at which the earliest MRSA lineage harboring the SCCmec appeared was about the mid-1940s, the era of methicillin [257]. The research field of staphylococcal cell wall structure has gradually gained in its significance [258]. Streptococcus pneumoniae has a complex cell wall that plays a key role in contributing to pneumococcal resistance to lysozymes [259].

\subsection{Enterococci: The Gram-Positive "Vanguards" of the "MDR Movement"}

Enterococcus species (Ent. faecium, Ent. faecalis, Ent. gallinarum, and Ent. cecorum; for taxonomy, see Wikipedia) are facultative anaerobes that exist as commensals in the gastrointestinal tract of a variety of organisms, including humans [260]. Six penicillin-binding proteins (PBPs) were identified in the first clinical isolates [261]. From samples studied, Ent. faecium was found to be the most resistant to, and showed the lowest affinities for, penicillin, while Ent. bovis was the most penicillin-sensitive and showed the highest affinity [261-263]. When streptomycin was discovered [262], it was applied together with penicillin [262], and the synergistic effect seemed to work [264]. However, this combination provided a selective condition for MDR enterococci [263].

MDR enterococci strains are adapted to the gastrointestinal tract and can become the dominant flora $[265,266]$. The first epidemic MDR Ent. faecium strain emerged from animal and commensal strains $[267,268]$. Enterococci have been, and remained, a prominent Gram-positive pathogen in the SENTRY (Antimicrobial Surveillance) Program from 1997 until now [269]. The most common Enterococcus pathogen species are Ent. faecalis (64.7\%) and Ent. faecium (29.0\%) [269]. Enterococcus faecum became the most important nosocomial pathogen, posing a growing clinical challenge because of its rapidly evolving antibiotic resistance repertoire, practically against all clinically used antimicrobials. Enterococci use many spectacular genetic strategies [270-272].

The MDR enterococci have individual combinations of genuine antibiotic resistance mechanisms [38-41,273-278]. The resistance mechanisms include modification of drug targets [38], inactivation of therapeutic agents [272,279,280], and overexpression of efflux pumps [38,281,282]. For more details, see Supplementary Material 2.

Their dynamic cell envelopes serve as their first line of defense against antimicrobials [264,283]. Peptidognt, ycan (PG), is a well-established target for antibiotics [284-287]. Components, like teichoic acids, capsular polysaccharides (CPS), surface proteins, and phospholipids, can undergo modifications and reduce the susceptibility to antibiotics [288-290].

\subsubsection{Comparative Genomics of Enterococci: Species, Strains, Clades Resistance Groups}

The recent way to identify of Enterococcus species has been based on a simple assay of the groEL gene [291]. Comparative genomics showed that the MDR Ent. faecium genetic clade A1 [291-295] had separated evolutionarily from the animal-adapted Ent. faecium [295-297] at about the same time as penicillin and streptomycin were jointly introduced into clinical use [297]. 


\subsubsection{Clinically Adapted and Non-Clinical Enterococcus strains}

Clinically adapted Enterococcus strains are still evolving from commensal strains, such as CC17 from Ent. foecium, but not from Ent. faecalis [266,267,298,299]. Clinical and non-clinical strains of Ent. faecium have distinct structural and functional genomic features [300,301].

\subsubsection{MDR Potential of Enterococci}

For the genetics and genomics of ampicillin resistance in Ent. faecium, see the comprehensive review by Zhang et al. [302]. Evolutionarily separated clinical strains intensively collect mobile genetic elements, resulting in alterations in hyper-mutability that lends Ent. faecium its remarkable genome plasticity [303]. Enterococci serve as donors of antibiotic resistance gene clusters, including vancomycin resistance [304-309] and daptomycin resistance [310], to other Gram-positive pathogenic micro-organisms including MRSA [310].

\subsubsection{Vancomycin-resistant Enterococcus faecium VRE [298] as a Leading Cause of MDR} Hospital Infections

In the Enterococcus genus, the vancomycin resistance (VRE) gene clusters are classified into nine types according to their gene sequences and the organization (reviewed by Chen and $\mathrm{Xu}$ ) [311]. The latest review on the genomics of Ent. faecium VRE summarized the new insights into VRE evolution, drug resistance, and hospital adaptation based on whole-genome sequencing [312,313].

Two genetically definable Ent. faecium populations are the hospital-adapted MDR (including vancomycin-resistant) isolates (Clade A) $[268,293,312,313]$ and vancomycin-susceptible commensal strains (Clade B). The majority of five VRE isolates collected from different sites belong to VanA [269,314]. However, the isolate VanN [315], which had previously been found in chickens in Japan [316], and then was also found in a hospitalized patient in Canada [317], emerged recently from a commensal (CladB) isolate [268].

4.2.5. Enterococcus cecorum: An Example for the Recent Speedy Development of Antibiotic Multiresistance in Genus Enterococcus

A normal commensal intestinal inhabitant is increasingly responsible for outbreaks of arthritis and osteomyelitis in chickens. Since 2002, Ent. cecorum has been recognized as the causative pathogen of enterococcal spondylitis (ES) [260,318-328]. Enterococcus cecorum was known as a harmless commensal of the gastrointestinal tract of chickens. However, in the last one-and-a-half decades, new pathogenic isolates of Ent. cecorum have been an increasingly significant cause of morbidity and mortality in broiler chickens, and frequent outbreaks are reported, although an environmental reservoir for pathogenic Ent. cecorum has not been found. Classical genetic analyses of Ent. cecorum demonstrated that strains with increased pathogenicity are genetically related, and share several virulence genes and antibiotic resistance genes, when compared to commensal strains. These pathogenic strains can be recovered from retail meat, and they may serve as a reservoir for further spread of antimicrobial resistance among other Enterococcus spp. [329]. For more details, see Supplementary Material 3.

\subsubsection{Vancomycin, Vancomycin Resistance; Daptomycin, Daptomycin Resistance}

Vancomycin is a non-ribosomal (NRP)-templated glycopeptide from Amycolatopsis orientalis [330,331]. It was used against Gram-positive targets, both intravenously and per os [332,333]. When taken by mouth it is poorly absorbed. Vancomycin acts by inhibiting proper cell wall synthesis in Gram-positive bacteria [38,334].

Vancomycin resistance: After the discovery and introduction of the omnipotent antibiotic vancomycin, it was considered the last resort, or "card" in the "card game" of pharmaceutical science, for Gram-positive pathogens [38]. Since the appearance of vancomycin-resistant enterococci strains in the late 1980s, the number of resistances has been steadily rising, both in Enterococci [14,271,335], 
and Staphylococci $[336,337]$. Many resistance isolates appeared, often with life-threatening consequences [337-340]. As an alternative to the generation of completely new substances, novel approaches have focused on structural modifications of vancomycin to overcome these resistances and to restore its efficacy against vancomycin-resistant enterococci $[334,340]$. The most recent knowledge about the mechanism of vancomycin resistance has been summarized [341].

\subsubsection{Daptomycin (DAP)}

Daptomycin [342-352] is a cyclic anionic lipo-(dipepsi) lipopeptide, which includes three D-amino acid residues (D-asparagine, D-alanine, and D-serine) linked to a hydrocarbon tail, ten carbons in length, derived from decanoic acid [347]. It is biosynthesized by S. roseosporus from a soil sample gathered from Mount Ararat, Armenia [348]. DAP was introduced as a new drug against S. aureus (MRSA) and vancomycin-resistant enterococci (VRE), vancomycin-intermediate S. aureus (VISA), and penicillin-resistant S. pneumoniae [344,349-351].

A spectacular genetic analysis, including transposon mutagenesis [352] and molecular cloning [353], allowed discovery of the biosynthetic pathway of DAP. There are perspectives of improved production of DAP by exploiting the potential of genetic manipulation of secondary metabolite biosynthesis [354]. The total chemical synthesis has also been done [354].

\subsubsection{Daptomycin Resistance DAP (R)}

The discovery of the mode of action of daptomycin [355] helps to handle daptomycin resistance problems. Intensive studies on daptomycin-resistant (DAP-R) mutants have also been discovered in enterococci [349] [356,357]. This has resulted in revealing the mechanisms of DAP-R in different Gram-positive bacteria [38-41,273], including B. subtilis [358], Enterococci [359-362], Ent. faecalis [361], Ent. faecium [362-364], and S. aureus [365-368]. Mutations of DNA "mismatch repair" genes in a DAP-R pleiotropic phenotype were discovered in a clinical isolate of Ent. faecium [369].

\section{The Efforts to Discover Omnipotent ("Jolly Joker") Antibiotics to Overcome MDR Problems}

\subsection{Teixobactin: The First Omnipotent ("Jolly Joker") Antibiotic Active Against Gram-Positive Targets}

The first antibiotic without detectable resistance was discovered in Kim Lewis' laboratory. Teixobactin inhibits cell wall synthesis by binding to a highly conserved motif of precursor peptidoglycan lipid II and precursor of cell wall teichoic acid-lipid III (a) [370]. No S. aureus nor Mycobacterium tuberculosis mutants have been found to be resistant to teixobactin so far [371]. However, resistance mediated by D-stereospecific peptidases cannot be ruled out in the future [372]. Teixobactin is a non-ribosomal peptide (NRP) antibiotic, which contains D-amino acid. The total synthesis and structure-activity relationships of teixobactin have been conducted [373], and lactam and ring-expanded analogs are also available [374]. Teixobactin provides a new perspective for using antibiotics in the treatment of mycobacterial infections [375].

\subsection{Narrow/Spectral Pluripotent Antimicrobial Peptides}

We consider antimicrobial peptides (AMPs) as any polyamide (or even biopolymer with ester, thioester, or otherwise modified backbone) that can be made on a contemporary chemical peptide synthesizer, and that exerts antimicrobial activity [376]. The antibiotic-resistant bacteria show widespread collateral sensitivity to antimicrobial peptides [377], as discussed later in detail.

AMPs are either of natural origin, such as those isolated from insects [378], or designed [379] either by computer [380], following QASR-studies on the designer molecule [381] or after synthetic (experimental) precursor manipulation [382]. The natural AMPs are part of the inherent immune system in all known taxa but Archaea, [380,383], and many of them were found to be effective against multiresistant pathogens, usually, with high selectivity [383] Encodings and models for antimicrobial peptide classification for multi-resistant pathogens have then been developed, [383]. 
Based on conclusions drawn from QSAR and in vitro bioassays the putative promising chemical derivatives will then be structurally optimized [384]. Synthetic candidate derivatives including those substituted with unusual amino acids [385] share unique features such as serum stability, lack of side effects, and owing intracellular target specificity. The discovery of a new natural AMP molecule is usually followed by quantitative structure/activity (QSAR) studies [381], and then the design and optimization of analog molecules [379-385] then the best ones finally will chemically be synthesized. The most promising molecular family is the proline-arginine rich peptide (PrAMP) [386]. including pyrrochorrycins [386,387], apeadicins [388,389], and oncocins [390]. Some of them are in a preclinical stage [391,392]. All of these are narrow spectral AMPs. Some were more efficient in vivo than in vitro, supposedly due to cooperation with the innate immune system of the host to be protected [376,386-392].

\subsection{Large Spectral Pluripotent ("Jolly Joker" Candidate) Non-Ribosomal Encoded (NRP) Biosynthetic Antimicrobial Peptides}

Omadacycline aminomethylcycline is a semisynthetic derivative of tetracycline, and it is active against many Gram-negative bacteria and Gram-positives, including MRSA, S. aureus, S. pneumoniae, $\beta$-hemolytic streptococci, Enterococcus VRE, and Enterobacteriaceae in vitro [393] and in vivo in clinical practice [394]. Similar activity has also been found in the thermostable antimicrobial peptide discovered in Hungary in Xenorhabdus budapestensis and X. szentirmaii [31,395-399] and later identified as fabclavine [400-405].

\subsection{Efflux Pump Inhibitors (EPIs)}

Efflux pump inhibitors (EPIs) had great potential, but the putative drug candidates were toxic [406]. Two new carbapenem- $\beta$-Lactamase inhibitor combinations were introduced [151]. In the last years, several hundred thousand people developed multidrug-resistant tuberculosis (MDR-TB), requiring a new effective treatment. It was found that efflux pumps play an important role in the evolution of drug resistance. New strategies are required to mitigate the consequences of the activity of efflux pumps [130].

\section{Adaptive Evolution: Trends and Mechanisms in Relation to MDR-Posed Danger}

Antibiotic multiresistance has an obviously increasing worldwide tendency an evolutionary trend. The real question is whether the evolution of MDR is an irreversible one-way street.

\subsection{Resistance vs. Persistence: Darwinian and Lamarckian Approaches}

The proper approach for trying to slow down the rapid evolution of resistant bacteria requires a full understanding of the mechanisms of adaptive evolution [68,407-409]. The problem with the similarities between resistant and tolerant phenotypes is that tolerance can be associated with the failure of antibiotic treatments [410]. The correct and precise definitions of the terms of tolerance, persistence, persistent, and resistance have been provided in "opinion papers" [410] and confirmed by the Consensus Statement found in Balaban and her associates [411].

The phenotypic similarities between resistance and persistence led to Darwinian- and Neo-Lamarckian-inspired research approaches. Resistance is a phenotypic expression of a resistance allele and is specific for an antibiotic with a unique structure. This allows the microorganism to grow in the constant presence of the antibiotic within a concentration range [412].

This can be quantitatively characterized by a Minimal Inhibiting Concentration (MIC). On the other hand, tolerance (the synonym of persistence) [413] provides a general, not antibiotic-specific protection. Inheritable persistence is a pleiotropic phenotype with loss-of-function alleles from many genes with completely different functions [414], called toleromes by Brauner et al. [410].

Non-inherited persistence is inducible [415-417], fitness-decreasing [418], and in a dormant stage [413]. This is the phenotype of the epigenetic subpopulation [419-421] that remains in the culture after the actively respiring bacteria have been vanquished by antibiotics $[422,423]$. 
The Minimum Duration for killing (MDK99) is the quantitative parameter designed to evaluate the tolerance level of the population treated with antibiotics [410]. The epigenetic persisting subpopulation, with a non-inherited persistent phenotype, has a clear adaptive value [424-427]. It serves as a sheltered evolutionary reservoir [428] from which antibiotic-resistant mutants may emerge [426,427]. Potentially, "persistence invites resistance" [429], but it appears that persistence may, but not must, precede resistance [429-431]. Persistence-based antibiotic resistance research efforts are of key importance from the aspect of elaborating anti-persistence strategies [432-441], but this is out of the scope of this review.

\subsection{An Introduction to Experimental Evolution}

The 60-year history of genomic research, which helped reconstruct mobile genetic elements harboring genes responsible for multidrug resistance of pathogens, has recently been reviewed [407,442]. The spread of many multidrug-resistant (MDR) bacteria is predominantly clonal. Interestingly, international clones/sequence types (STs) of most pathogens emerged and disseminated during the last three decades [443]. This kind of evolutionary processes can be monitored or experimentally recapitulated. Bottlenecks reduce the size of the gene pool within populations of all, with implications for their subsequent survival. By reducing genetic diversity, bottlenecks may alter individual or population-wide adaptive potential [444]. Here we discuss some other aspects directed to antibiotic resistance.

\section{Resistance Evolution and Mobile Genetic Elements in Enterococci}

Gilmore and his associates wanted to determine how the enormous accretion of mobile elements affect the competitive growth of enterococci in the gastrointestinal tract consortium [303,445]. They observed that the prototype clinical isolate strain (V583) was actively killed by the gastrointestinal tract flora, while commensal enterococci flourished. They found that the death of V583 resulted from lethal crosstalk between accumulated mobile elements, and that this crosstalk was induced by a heptapeptide pheromone produced by native Ent. faecalis present in the fecal consortium [303]. They concluded the accumulation of mobile elements in hospital isolates of enterococci can include those that are incompatible with native flora. That is, in the absence of antibiotics, wild type (commensal) bacteria can win the competition with MDR pathogens.

\subsection{Resistance Is Not a Positive Selection Marker in a Commensal Niche-The Lesson Learned from Population Genetics and Monitoring Evolutionary Processes}

The virulent, globally disseminated, multidrug-resistant lineage ST131 of E. coli can cause urinary tract infections and bacteremia $[443,444]$. To differentiate ST131 from the larger E. coli population associated with a disease, Kallonen and his colleagues isolated samples from various parts of England for genomic analysis under the framework of a systematic 11-year hospital-based survey [446]. They concluded that antibiotic resistance must not have been the predominant reason for the prevalence of $E$. coli lineages in this population, but the frequency of $E$. coli lineages in an invasive disease was driven by negative frequency-dependent selection, acting in the commensal niche outside of the hospitals. This research team later showed that the predominant multidrug resistant $E$. coli clones, under the influence of negative frequency-dependent selection, are prevented from rising to dominance in a population [447].

In a long-term (2001-2014), worldwide analysis of enterococci and vancomycin-resistant enterococci (VRE) causing invasive infections, Mendes and his team evaluated the prevalence and in vitro susceptibility of enterococci and VRE in bloodstream infections in European and US hospitals [448]. Through a SENTRY Surveillance Program, Mendes and his associates found that the VRE rates among Ent. faecium increased both in Europe and the USA. The multidrug-resistant (MDR) phenotype was a positive selective trait of antibiotic stress under hospital conditions. 


\subsection{The Loading Capacity of the Bacterial Genome Is Limited-The Lesson Learned from Experimental Evolution}

Escherichia coli is an ideal organism for experimental evolution. Most changes to its metabolic network that survived over the past 100 million years, which are adapted genetically to the environment, are due to horizontal gene transfer, with a very low contribution from horizontal gene transference $[407,442]$. Experimental microbial evolution studies use controlled laboratory populations to evaluate the mechanisms of evolution and are based on molecular, genomic, and maybe transcriptomic and proteogenomic analysis over several generations of evolving populations in controlled, pre-established conditions in a morbidostat [449-451] or in a DiVERGE [452]. The srecently developed technolog, enables researchers to carry out testing on empirical prediction ns of a given evolutionary theory $[453,454]$. The data from the literature gave an impression that a new antbitoc resistance is a positive selection marker in antibiotic stress conditions but is a negative selection marker in commensal milieu (as demonstrated on Figure 2A).

\subsubsection{Evolutionary Trends in The Presence of Antibiotics}

Toprak and his associates experimentally recapitulated the evolution of antibiotic resistance developed in E. coli against several different antibiotics, and they found a gradual increase in resistance levels of each antibiotic tested during the experimental period [455]. The whole-genome sequencing of the evolved strains revealed mutations including resistant ones to the given drug or resistant ones to more than one drug. Resistance could be developed either in a stepwise manner in replicates (trimethoprim) or via diverse combinations of mutations in different genes (chloramphenicol and doxycycline). For interactions between the presence of an antibiotic and resistance evolution, the evolutionary dynamics were monitored by whole-genome deep sequencing every 3 to 4 days in another Gram-negative pathogen organism, P. aeruginosa. During the experimental period, the resistance level to colistin increased by one order of magnitude in 10 days and two orders of magnitude in 20 days, supposedly due to mutations in the mutS mutator gene [456].

Resistance, Fitness, and Compensatory Mutations

The antimicrobial pressure may drive the evolution of its resistance, which may be associated with reduced bacterial fitness. There is evidence that the probable "evolutionary price" of a new antibiotic resistance is lowering fitness, and it must be determined genetically [457-460]. The phenotypic consequences are reflected in the geometry adaptations [461,462]. However, compensatory mutations [461] may change the pattern and might be an explanation of the dissemination of colistin-resistant $A$. baumannii isolates $[63,463]$. This might be an explanation for the dissemination of colistin-resistant $A$. baumannii isolates [203]. Using precise, high-throughput fitness measurements for genome-wide $E$. coli gene deletion strains, with eight antibiotics, the width of the distribution of fitness effects (so-called DFE) mutations, which occur spontaneously from one antibiotic to another, is lower than in the absence of the antibiotic stress [462]. Unlike the DFE mutations, the magnitude of the changes in tolerated drug concentration, resulting from genome-wide mutations, are similar for most drugs but are exceptionally small [464].

\section{Collateral Sensitivity}

In a large-scale laboratory evolutionary experiment, Lázár and her associates discovered a novel trend in the evolution of antibiotic hypersensitivity in E. coli called collateral sensitivity [377,465-468]. Some populations which became adapted to amino-glycosides have especially low fitness in the presence of several other antibiotics. The whole-genome sequences of 63 independently evolved amino-glycoside-resistant strains demonstrated multiple mechanisms based on reduced proton-motive force (PMF) through the inner membrane. The comparison of captured determinants of the antibiotic cross-resistance interaction network demonstrated that convergent molecular evolution was predominant across antibiotic treatments, and the resistance encoding mutations simultaneously 
enhanced sensitivity to many other drugs [465]. This phenomenon is called collateral sensitivity [and illustrated on Figure 2B. As mentioned before, antibiotic-resistant bacteria show widespread collateral sensitivity to antimicrobial peptides [377].

\section{Antibiotic and Antimicrobial Resistance Genes are of Different Mobility Patterns}

The antibiotic-resistant bacteria not only showed an unexpectedly high frequency of collateral sensitivity to antimicrobial peptides, while cross-resistances between the strains were rather rare [390], but clinically relevant multidrug-resistance mutations also increased susceptibility to antimicrobial peptides. As for mechanisms, collateral sensitivity in multidrug-resistant bacteria arise partly through regulatory changes shaping the lipopolysaccharide composition of the bacterial outer membrane. This information allows the identification of antimicrobial peptide and antibiotic combinations that enhance antibiotic activity against multidrug-resistant bacteria and slow down de novo evolution of resistance [377,468]. Furthermore, while the antimicrobial peptide (AMP) resistance genes are widespread in the gut microbiome, their rate of horizontal transfer is lower than that of antibiotic resistance genes [469]. Gut microbiota culturing and functional metagenomics have revealed that AMP resistance genes originating from phylogenetically distant bacteria have only a limited potential to confer resistance in E. coli, an intrinsically susceptible species [469].

\subsubsection{Evolutionary Trends of Antibiotic Resistance in the Absence of Antibiotic Exposure}

Antibiotic use is the main driver in the emergence of antibiotic resistance. In a set of experiments with E. coli, it was demonstrated that in the absence of an antibiotic and resistance evolution, drug-resistance frequently declined within 480 generations during exposure to an antibiotic-free environment.

The extent of resistance declination seemed antibiotic-specific and driven by mutations influencing both the resistance level and fitness probably pleiotropically [469]. It was concluded that a phenotypic reversion to the antibiotic-sensitive state may be mediated by the acquisition of additional mutations while maintaining the original resistance mutations [469]. This result might be an important argument against the selective virtue of antibiotic resistance in general.

However, in a set of experiments on another Gram-negative pathogen, P. aeruginosa, an opposite trend was demonstrated. It is difficult to interpret this contradiction. It was demonstrated that selection in the absence of antibiotics did co-select for decreased susceptibility to several antibiotics. This was considered as experimental evidence confirming the selective virtue of antibiotic resistance in a commensal niche [468]. The interpretation of these results by the authors is that resistance evolved coincidentally in response to other selective pressures. Thus, genetic adaptation of bacteria to natural environments may drive resistance evolution by generating a pool of resistance mutations, where selection could act to enrich resistant mutants when antibiotic exposure occurs [470].

\subsubsection{Phylogenetic Limitations: Species Specificity of the Antibiotic Resistance Genes}

Recent studies on transferring resistance-conferring mutations and full resistance genes into E. coli, from and to closely related species, have not been very successful. Resistance mutations originated from one bacterial species and transferred to another, and they rarely invoke a resistance phenotype. More frequently, the yield was drug hypersensitivity in close relatives, since the new gene could not fit the epistatic system of the new host, as was demonstrated in the case of the transferred aminoglycoside resistance (trkH) gene [471].

\subsection{The CRISPR/Cas Bacterial Immune System: A Molecular Tool to Get Rid of Unwanted Antibiotic Resistance}

Bacteria and Archaea have developed a system based on clustered, regularly interspaced, short palindromic repeats (CRISPR) from peculiar genetic loci. These repeats provide acquired immunity against viruses and plasmids by targeting the nucleic acid in a sequence-specific manner [472]. 
These hypervariable loci take up genetic material from invasive elements and build up inheritable DNA-encoded immunity over time. It was demonstrated that the $S$. thermophilus CRISPR1/Cas system can also naturally acquire spacers from a self-replicating plasmid containing an antibiotic-resistance gene, leading to plasmid loss. The most recent evolutionary classification of CRISPR-Cas systems and cas genes includes two classes, 6 types, and 33 subtypes. The discovery of numerous derived CRISPR-Cas variants is often associated with mobile genetic elements that lack the nucleases required for interference [473].

\section{Clonally Evolving Pan-Genomic ESKAPE Pathogens}

\subsection{Pseudomonas aeruginosa: A Pan-Genomic Hotbed of Multidrug Resistance}

The latest review on antibiotic resistance mechanisms in P. aeruginosa and alternative therapeutic strategies came out last year [474]. Our latest knowledge about the lifestyle of $P$. aeruginosa (for taxonomy: see Wikipedia) is that of a ubiquitous [475], invasive [476], opportunistic [477-480], facultative, pathogenic bacterium species. It can cause diseases in plant and animal species, as well as in humans [481], which has recently been summarized [482]. As a consequence of its evolutionary plasticity [483], based on open genome expandability [484-487], it is armored with a full arsenal of antibiotic multiresistance $[3,488,489]$. The majority of MDR P. aeruginosa displays a wide repertoire of antibiotic resistance mechanisms, including posttranslational modification of drug targets [490-492], enzymatic inactivation of antibiotic molecules [493], encoding genes of carbapenem-resistance preferably those coding for metallo- $\beta$-lactamase; overexpressing efflux pumps [494-496], and showing strong ability to form a biofilm [497-499].

Pseudomonas aeruginosa is one of the two pangenomic [499,500], Gram-negative pathogenic species, which has permanently acquired MDR encoding genes. It is a threatening source of resistance genes, which are transmittable via horizontal gene transfer [339,501].

\subsubsection{A Shortlist of Intrinsic and Acquired Antibiotic Resistance in P. aeruginosa}

The most recent overviews [487,489] provides "an ocular perspective" of the different mechanisms of antibiotic resistance in P. aeruginosa. Most strains are intrinsically resistant to third-generation cephalosporins due to chromosomal-encoded C beta-lactamase and AmpC [488,501]. The original intrinsic MDR-arsenal includes the production of beta-lactamases, loss of outer membrane proteins [500], and up-regulation of efflux pumps [502-507]. This species also acquired resistance to aminoglycosides and fluoroquinolones [487]. One of the acquired enzymes taken-up by P. aeruginosa, Pseudomonas extended resistance (PER) [508-511], a class of extended-spectrum beta-lactamase (ESBL), occurs less frequently but still is of clinical importance [512,513].

Pseudomonas aeruginosa uses different mechanisms that can jointly contribute to its multiresistant phenotype [512] and multidrug efflux systems [492,495,496,514,515]. All of this makes P. aeruginosa extremely invasive. The rapidly increasing number of new P. aeruginosa isolates of MDR, XDR, and PDR phenotypes severely reduces the antibiotic therapy options available [3]. Valuation of the economic cost of antimicrobial resistance (AMR) is important for decision making and should be estimated accurately, [516]. Colistin, which acts on outer membranes of bacteria resulting in its permeability and cell-death, was suggested five years ago as a salvage therapy in the treatment of life-threatening infections due to MDR P. aeruginosa blood-stream infections (BSI) [517]. Articles and reviews on resistance problems appeared one year later [518] and have been appearing since [205,214-217].

\subsubsection{Pseudomonas Genetics and Genomics}

Genetics: Most genes of intrinsic resistance are on the chromosome, including multidrug efflux pumps and enzymes responsible for resistance to beta-lactam and aminoglycoside antibiotics [519].

Genomics: A challenging option, provided by the next-generation whole-genome sequencing, as an approach to better understand and combat antibiotic resistomes [520], has been beneficially used 
in Pseudomonas research, as exemplified by Cao et al. [521]. An international consortium has been continuously providing comparative genomic information [522,523] and the prognosis [500] for clinical use. In addition. an antimicrobial resistance prediction concluded from the comparative genomics data of comparative sequence analysis of all available drug-resistant $P$. aeruginosa genomes could be realized [486,501,516,522,523].

Ramanathan and his associates studied single-nucleotide polymorphisms (SNPs) in ten multiantibiotic resistant $P$. aeruginosa clinical isolates [519]. Non-synonymous single-nucleotide polymorphisms (nsSNPs) were found in more clinical isolates compared to the reference genome (PAO1). The nsSNPs identified in the multidrug-resistant clinical isolates were found to alter a single amino acid in several antibiotic-resistant genes. They also found mutations in genes encoding efflux pump systems, cell wall, DNA replication, and genes involved in repair mechanisms. Furthermore, nucleotide deletions in the genome and mutations leading to a generation of stop codons were also observed in the antibiotic-resistant clinical isolates, and in specific mutations within antibiotic-resistant genes, compared to the susceptible strain of the same bacterial species [519].

\subsubsection{Transcriptomics}

So far, we have detailed knowledge of the behavior of P. aeruginosa under standard laboratory conditions, but we only have a superficial understanding of bacterial functions and behaviors during human infection. However, a recent study on transcriptomes in human infection revealed that multiple genes known to confer antibiotic resistance had substantially higher expression in human infection than under laboratory conditions [524].

\subsubsection{Resistance Phenotypes}

The first comprehensive review on this subject was published by Kempf and Rolain [525]. Mutations in pmrB confer cross-resistance between the LptD inhibitor POL7080 and colistin in $P$. aeruginosa [217]. Integrated whole-genome screening revealed that $P$. aeruginosa virulence genes use multiple disease models, and the pathogenicity is host-specific [8]. Biofilm formation is an important part of the pathogen strategy of this bacterium [526]. A list (incomplete) of Pseudomonas-caused human diseases is discussed in Supplementary Material 5.

\subsection{Acinetobacter baumannii}

\subsubsection{Species with a Gradually Expanding (Open) Pangenome}

The bacterium Micrococcus calcoaceticus was isolated from soil by enrichment in a calcium-acetatecontaining minimal medium [527]. It was finally moved to Moraxella [528] as a single representative of genus Acinetobacter in Bergey's Manual [529] under the name of A. calcoaceticus (type strain ATCC 23055) [529]. Acinetobacter baumannii was designated taxonomically after appearing as a human pathogen [530-533]. Acinetobacter baumannii is also a veterinary pathogen [534-538], but, unlike P. aeruginosa, it has not appeared as a plant pathogen. Acinetobacter baumannii is a very successful pathogen [539]. WHO declared that A. baumannii is one of the two most serious pangenomic ESKAPE organisms [540]. Since then, the rapid global evolution of MDR in A. baumannii has been carefully monitored, and clonal lineages of old and new isolates have been revealed [541]. Two long-term international global surveys have recently been carried out on $A$. baumannii as a potential health risk factor, as reported by Gales et al. and Flamm et al. [540,541].

\subsubsection{Resistance Mechanisms and Diseases}

The mechanisms of disease caused by A. baumannii strains have recently been reviewed by Morris et al. [8]. The latest review on the resistance mechanisms of A. baumannii [542] focuses on XDR resistance. 
As for its resistance mechanisms, tigecycline efflux was described as a mechanism for nonsusceptibility in A. baumannii. In addition, a deletion of TnAbaR23 resulted in significant antibiogram changes in a multidrug-resistant $A$. baumannii strain [543]. For more information see Supplementary Material 6.

\subsubsection{Genetic Dissection of Colistin Resistance in A. baumannii: Trebosc et al., 2019}

The transcriptional regulator PmrA was considered as the only potential drug target to restore colistin efficacy in A. baumannii [510], but the deletion of $p m r \mathrm{~A}$, the gene responsible for overexpression of the phosphoethanolamine, PetN, only restored susceptibility in a few strains. A detailed genetic analysis revealed a new colistin resistance mechanism mediated by genomic integration of the ISAbaI insertion element upstream of the PmrC homolog (eptA), leading to its overexpression. The gene eptA is present in each international clone 2 clinical strain, and a duplicated ISAbaI-eptA cassette was present in at least one clinical isolate, thus indicating this colistin resistance determinant may be embedded in a mobile genetic element [216].

\subsubsection{Genetics Toolkits to Becoming Multiresistant}

Acinetobacter baumannii, like other non-glucose-fermenting Gram-negative species such as $P$. aeruginosa, has increasingly been acquiring carbapenem resistance [544,545]. An argument against the worries [546] that $A$. baumannii increases the risk of carbapenemase spread in general, since horizontal resistance gene the transfer can occur between Gram-negative species, regardless of their ability to ferment glucose [545], is that experimentally transferred resistance mutations from other species to E. coli have been mostly silent, and frequently yield drug hypersensitivity [469].

\subsubsection{Sword of Damocles: Clonal Evolution, Global Spread, and Epidemic Potential of A. baumannii}

The different antibiotic resistance genes are organized into resistance islands in the genome of A. baumannii. The impression of the reviewers is that the MDR, XDR, and PDR must not be considered as simple collections of different antibiotic resistances, but they may represent a coordinated system based on sophisticated genetic background and genomic organizations. Based on the evolutionary analysis of six housekeeping genes, A. baumannii is of monophyletic origin $[531,546]$. Originally three predominant pathogen clones, called 'international clonal lineages' (ICLs), were known as being responsible for hospital outbreaks worldwide [547]. The monophyletic status of ICLs 1 and 2 have also been shown [38,548]. As reviewed first by Dijkshoorn et al. [546], the genome of a representative ICL1 (AYE) [549-551] strains include 52 genes associated with resistance to anti-microbial drugs, and 45 are localized in an $86 \mathrm{~kb}$ resistance island called AbaR5 [552]. ABAR1 is also present in other A. baumannii strains, but at a much smaller size. The presence of an extraordinary 22 gene-cassette coding for transposases and insertion sequences may be responsible for the acquisition of resistance genes into the AbaR1 island of the AYE ICL1-type strain [543]. Almost half are orthologous to coding sequences of Pseudomonas [546].

\subsubsection{Genome Plasticity}

The Acinetobacter baumannii calcoaceticus complex is considered as a species with an open pan-genome and is well-defined on Wikipedia. The complete genome [553-555] includes the core genome (genes present in all isolates) with extreme antibiotic resistance traits [554]. In addition, the accessory genome [555], including the genes absent from one or more isolates, or unique to a given isolate, also contains hosts antibiotic resistance genes but in different arrangements [555]. Antibiotic resistance genes are located both in the core and the accessory genomes [556]. In the latter, they were found in alien islands or flanked by integrases, transposases, or insertion sequences [556]. They must be acquired via horizontal gene transfer from other Acinetobacter strains to colonize the same environment [556]. The first detailed genomic analyses revealed that the existing A. baumannii clinical population consists of low-grade pathogens, whose pathogenicity relies mainly on an ability to persist 
in the hospital setting and survive antibiotic treatment [4]. This analysis led to the conclusion that A. baumannii has a high capacity to acquire new genetic determinants and displays an open pan-genome. This feature may have played a crucial role in the evolution of this human opportunistic pathogen towards clinical success [4]. The whole pangenome of $A$. baumannii consists of $>8800$ orthologous coding sequences, and it has exponentially been increasing as new genomes become available (an open pan-genome), mainly due to unique accessory genomes of different isolates enriched with acquired genes of transport and transcription regulation functions [4]. Since then, at least 15 complete, and $180 \mathrm{draft}$, chromosomal A. baumannii genomes, 31 plasmids, and six bacteriophage sequences have been available on the NCBI database, together with those of other species of the genus, and antibiotic treatment induces important genes [557]. The open pan-genome of $A$. baumannii also includes lots of plasmids, transposons, integrons, and genomic islands, which may contribute to the evolutionary success of this clinical pathogen. This is particularly true in the acquisition of multidrug resistance determinants [5], a tool for redefining this, and other, pathogenic bacterium species $[162,547,557,558]$.

\subsubsection{Will the Epidemic Threat Be Materialized?}

The population structure of A. baumannii comprises of a set of expanding multiresistant clones raised from an ancestral susceptible genetic pool [559-561], confirming that A. baumannii used to have low phylogenetic diversity, providing a narrow evolutionary bottleneck through which a micro-evolutionary tree with many branches has emerged [546]. Making this metaphor complete, each branch of that tree carries "dangerous fruit" called antibiotic-resistance (ABR) genes. All the other known Acinetobacter species are harmless soil-inhabiting ones [546].

Until recent years, A. baumannii has been almost exclusively isolated from locations of antibiotic stress conditions, that is, in hospital environments, (especially from intensive care units of hospitals) and veterinary clinics [562-564]. However, in 2017, A. baumannii DSM30011 was obtained from the resinous desert shrub guayule and may be considered as a "copy" of the first isolate, and whole-genome sequencing and phylogenetic analysis based on core genes confirmed DSM30011 affiliation to A. baumannii [565]. No antimicrobial resistance islands were identified in DSM30011, agreeing with a general antimicrobial susceptibility phenotype. The marginal ampicillin resistance of DSM30011 most likely derived from chromosomal ADC-type ampC and blaOXA-51-type genes [566]. The environmental Acinetobacter baumannii isolate DSM30011 reveals clues into the preantibiotic era genome diversity, virulence potential, and niche range of a predominant nosocomial pathogen [567] armed with efficient multidrug efflux pumps [567].

The "branches" of the original "tall" "micro evolutionary tree" are rather "long." ln the frame of a SENTRY study [543], Acinetobacter clinical isolates from 10 South Asian and Pacific countries were tested for being non-susceptible to imipenem or meropenem and positive for OXA-23-, OXA-24/40-, OXA-58-, and MBL-encoding genes [540,541]. The sword of Damocles (a global Acinetobacter epidemic) is still possible, but has not yet been dropped down.

\section{Concluding Remarks}

We must apologize for omitting so many excellent publications from this field because of space limits.

\subsection{Forcasts Based On Evolutionary Data}

\subsubsection{The Main Question}

Whether the post-antibiotic era is at the gate, or there is a chance to prevent its coming, is the question of questions. The literature convinced us that the trend of the global expansion of clonally spreading MDR and XDR pathogens is not irreversible. The post-antibiotic era is not inevitable. Let us discuss the arguments for and against these statements. 


\subsubsection{The "Combat Scenario"}

Nature and science have long been battling. Science produces antibiotics, nature presents pathogens with resistances. Nature has gradually become more sophisticated and better organized. The MDR or XDR phenotype cannot be considered as a brute summary of the expression of ad hoc collected (intrinsic and acquired) antibiotic resistance alleles. MDR (or XDR) represents a concerted phenotypic expression of structurally and functionally organized (operons, cassettes, integrons), and coordinated (resistomes) resistance alleles, which had been selected by the evolution. Both the intrinsic occurrence and the uptake of resistance alleles are random.

\subsubsection{Adaptive Evolution}

The selective drives acting in the commensal niche and those acting in a milieu under selective (antibiotic) pressure are different. A neutral mutant allele, including those encoding resistance, in a commensal niche may be fixed in the population on the condition that it does not display a heavy genetic load, that is it does not express a negative fitness affecting (DFE) phenotype]. That is, it does not have either a positive or a negative selective value. Therefore, new antibiotic resistances are expected to appear in the future as in the past.

Neutral mutant alleles, including resistance-encoding ones, in a commensal niche may be fixed in the population on the condition that it does not display a heavy genetic load, or if it does not express negative fitness affecting (DFE) phenotype. That is, it does not have either a positive or negative a selective value. Therefore, new antibiotic resistances are expected to appear in the future, as in the past.

A mutant allele with a strong antibiotic resistance phenotype will expectedly be lost, or at least prevented from domination, or selectively lost in commensal conditions if it represents a heavy genetic load. This phenomenon is demonstrated in the monitoring studies on Gram-negative and Gram-positive MDR pathogens. However, the same allele will be enriched in the population up to $100 \%$ under selective (antibiotic) stress conditions, either in a hospital environment or in the laboratory.

\subsubsection{The "Dialectics" of Resistance and Sensitivity}

There are exceptional situations when the same gene can act as a resistance or a sensitivity gene, in the same species, depending upon genetic background (Supplementary Material 4).

\subsubsection{Collateral Sensitivity: A Biochemically Proven Limiting Factor in MDR Evolution}

For evolutionary success (winning the "permanent war"), the pathogen needs to carry strong and heavy "weapons" (MDR combinations), which also increases the genetic load. The rediscovery, genomic, and evolutionary interpretation of the collateral sensitivity is the most important experimental proof that the resistance capacity of a bacterium is limited. It means that "trees cannot grow up to the sky". The credibility of this discovery is also supported by biochemical evidence]. The molecular technique for getting rid of an unwanted resistance is probably the CRISPR/Cas Bacterial Immune System.

This conception is illustrated in an allegoric way on Figure 2. The higher resistance level makes the pathogen stronger in selective but weaker in non-selective (commensal) conditions. (Figure 2A-H). This explains collateral sensitivity as well. A limited number of resistances can be harbored, but not more. If the pathogen gains a new one (\#11 in Figure 2G, and \#13 in Figure 2H) it must get rid of another one (\#1 Figure $2 \mathrm{G}$ and \#3 on Figure 2H). The data in the last report of the HAI Consortium on changes in antibiotic resistance profiles of MRSA clones in the USA indirectly confirm that collateral sensitivity is not a laboratory artifact [256]. 
GRAM NEGATIVE WORLD AntiMicrobial Peptides (AMPs)

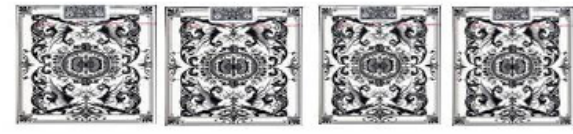

(Is "The JJ" amongst them?)

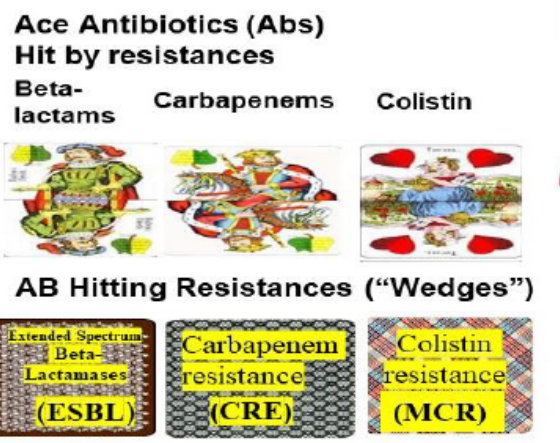

GRAM POSITIVE WORLD

AntiMicrobial Peptides (AMPs)

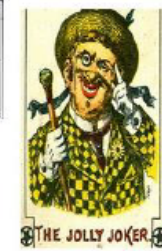

GIHE JOLLY JOKER

AMP,

not hit

(yet):

Teixobactin

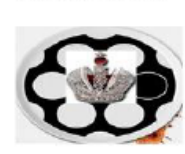

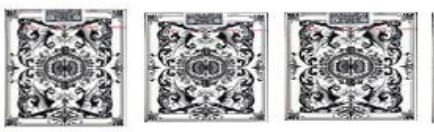

$56-51$
$6 e^{250}$
253

Ace Antibiotics (Abs)

Hit by resistances

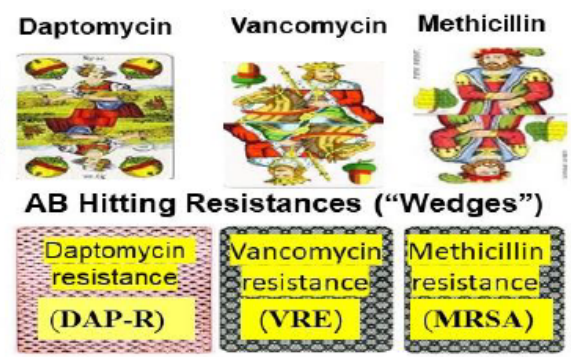

Figure 1. Illustration of the competition between new antbiotics and invoed resistances. The "Card Game" between science (designers of antibiotics) and nature (antibiotic resistance profile designing pathogens). Legend to Figure 1. Both with the Gram-negative (left) and the Gram positive (right) "card tables", the respective uppermost row represents the cards in the hands of science (antibiotics, antimicrobial peptides), and the lowest line is the cards (resistances) in the hands of nature. Science put down the "first card", penicillin (let us refer to it as a "Jack"). However, nature replied with the "wedge", called penicillin-resistance, acting as a trump-card to hit "Jack" in both the Gram-negative and the Gram-positive "card games". Then, science put down its' "queen" to hit this "wedge" in both "card-games": the beta-lactams, such as the amino-penicillin family for the Gram-negative and methicillin for Gram-positive "card games". They worked properly until nature produced new "wedges" (resistances): the extended spectral beta-lactamases (ESBL) and methicillin-resistance (MRSA), acting as trump cards in the Gram-negative and the Gram-positive "card games", respectively. Then, science put down "kings" to hit the queen-hitting wedges: carbapenems to overrule ESBL, and vancomycin to overrule MRSA in Gram-negative and Gram-positive "card games", respectively. Soon after the introduction of the "kings", nature produced king-hitting trump card "wedges" such as CRE (carbapenem resistance) in the Gram-negatives and vancomycin-resistance (VRE in Enterococci and VRS in Staphs) in the Gram-positive "card games". "Ace" antibiotics have become urgently needed. The Science took out the "old card" colistin (polymyxin) as an "ace" against the Gram-negative, and the newly discovered antimicrobial peptide against Gram-positives. However, Mother Nature produced new "wedges" again, the colistin- and daptomycin- resistance bacteria. As the game ramps up, "Jolly Jokers" are now needed and being searched for. The first potential "Jolly Joker", teixobactin [382], was active on Gram-positives. It was isolated and identified 4 years ago, and since then has not invoked resistance. Additional "Jolly Joker" antibiotics acting against both Gram-positive and Gram-negative targets are still needed.

\subsubsection{Counterarguments}

An experimentally supported counter-argument is compensatory evolution [461]. Another fact taken into considerations is that neither E. coli nor $S$. aureus is a pangenomic species. It is unknown whether the pangenomic pathogen species (A. baumannii [532], P. aeruginosa [462], K. pneumoniae [225]) were able to compensate for the genetic load by expanding their genome. They can withstand an increased number of resistances by exploiting their evolutionary plasticity and disseminate clonally or polyclonally. They serve as a permanent hotbed of other MDR pathogens [439]. Fortunately, there are phylogenetic barriers to horizontal transfer of antimicrobial peptide resistance genes in the human gut microbiota [466,469]. Another optimistic message from experimental evolution is that the majority of antibiotic resistance genes are species-specific and do not increase, but rather decrease, the MDR phenotype if they are uptaken by E. coli. [469]. 


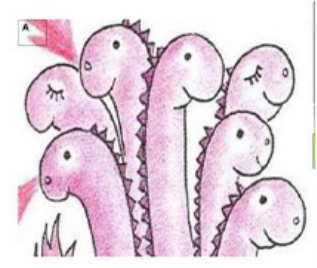

$[\mathrm{A}]-[0 \mathrm{R}]$

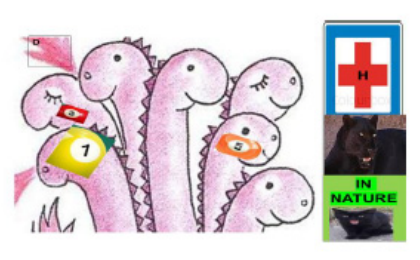

[D] $-[3 R]$

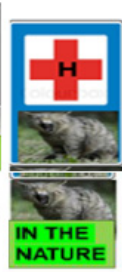

NTHE . (1)

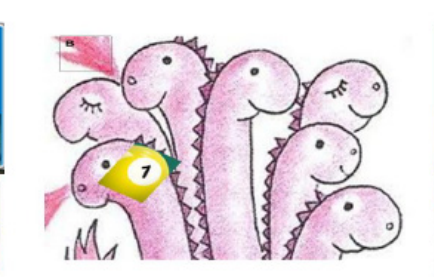

[B] $-[1 \mathrm{R}]$

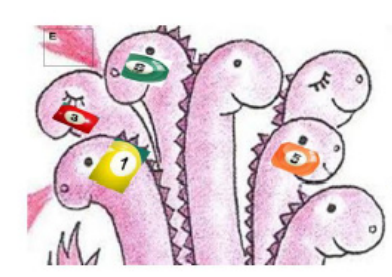

$[E]-[4 R]$
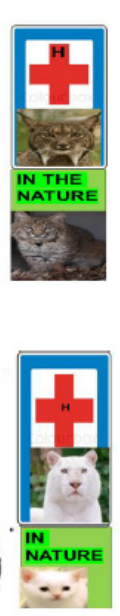

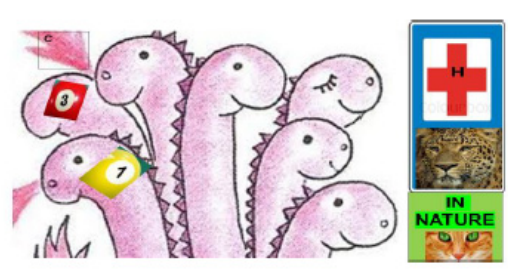

$[C]-[2 R]$

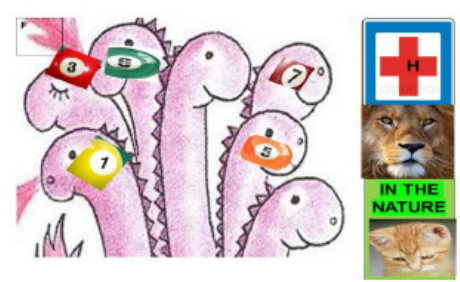

$[F]-[5 R]$

(A)

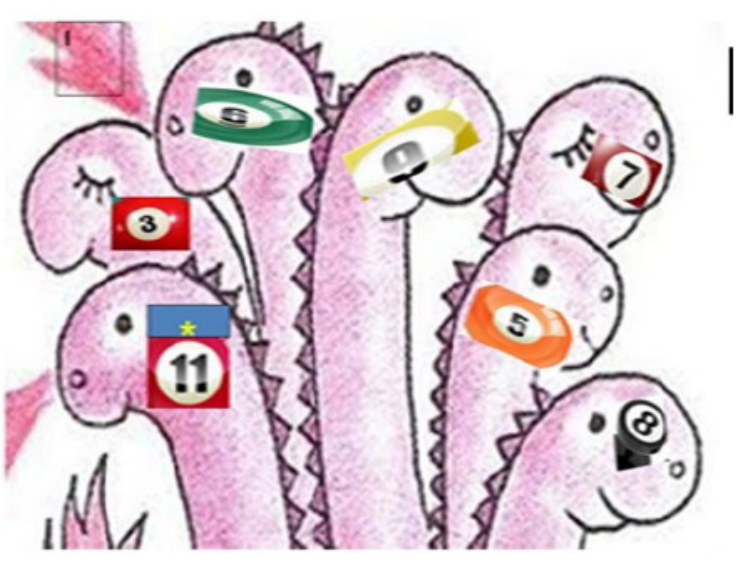

[G]

[R11 acquired, R1 lost]

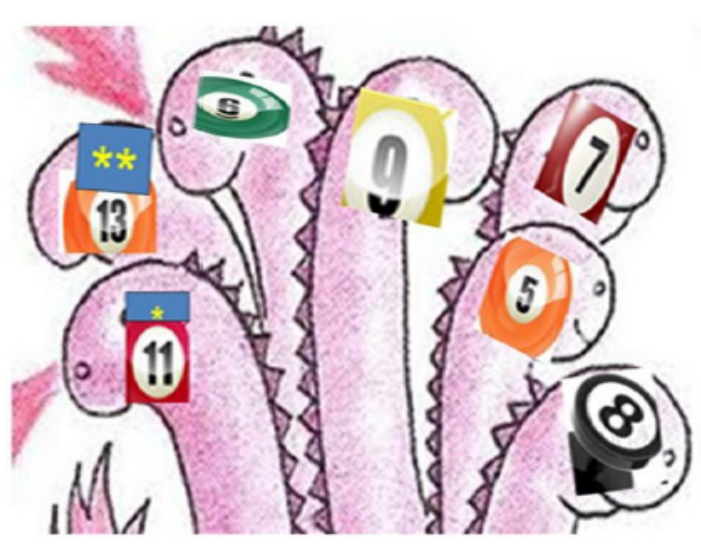

$\mathrm{IH}]$

[R13 acquired, R3 lost]

(B)

Figure 2. Illustration of Collateral Sensitivity. Trees do not grow to the sky: a metaphoric illustration that the MDR pathogens cannot be overwhelming winners in nature. In Figure 2, the pathogen bacterium is illustrated as a seven-headed monster. (A) demonstration of different trends of adaptive evolution in commensal and hospital environments. (A) Each new antibiotic resistance ([A]- $[0 \mathrm{R}]$; $[B]-[1 \mathrm{R}] ;[\mathrm{C}]-[2 \mathrm{R}] ;$ [D]—[3 R]; [E]—[4 R]; [A]—[5 R]) elevates the genetic load and reduces fitness, which makes the pathogen more vulnerable in antibiotic-free (commensal) conditions symbolized as nature (A). Under antibiotic stress conditions, hospital resistance as a positive selection marker makes the pathogen even more powerful and dangerous. (A) A pathogen without antibiotic resistance $(R=0)$ has similar strength in the hospital and in nature (the pathogen is symbolized as a wild cat). (B) One antibiotic resistance $(\mathrm{R}=1)(\# 1)$ makes the pathogen a little stronger (an ounce) in the hospital and a

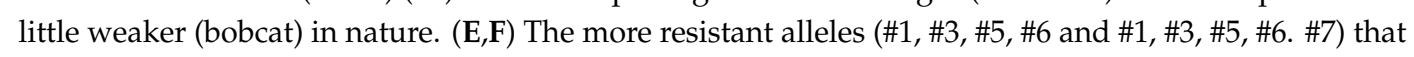
are present, the more strength in the hospital (symbolized ounce and lion, respectively) and elevated weakness ("baby cats") in nature. (B) Demonstration of collateral sensitivity. (G,H) The load-bearing potential must be limited, at least the phenomenon of collateral sensitivity seems to support this forecast. When the hypothetical seven-fold resistant pathogen (resistant to antibiotics \#1, \#3, \#5 \#6, \#7, \#8, and \#9) acquires an 8th $\left(\# 11^{*},(\mathbf{G})\right)$ and a 9th $\left(\# 13^{*},(\mathbf{G}, \mathbf{H})\right)$, resistance, respectively, it drops out resistance \#1 and \#3, respectively. 
Theoretically, however, epidemics caused by any of the three pangenomic pathogenic species might break out at any time. Our view is that since all but K. pneumoniae should be considered as a first-grade pathogen, the epidemic danger may not be immediate. However, immunocompromised patients in hospital environments are at permanent risk.

\subsection{Statistic-Based Conclusions from the Frequencies of MDR-Related Publications in PubMed}

We drew some conclusions from the temporal distribution of MDR literature in the last decade. The publications convinced us that only the monoclonal-spreading pangenomic pathogen species display a global epidemic threat. Naturally, it should not be underestimated. However, the nearly even temporal distribution of the literature seems to be an indicator of a permanently dramatic, rather than an alarming, situation.

All three tables should be evaluated together. Table 1A-C shows a dramatic increase in the number of reports on new resistant isolates of each Gram-negative ESKAPE species. No report was found about XDR or PDR, concerning the non-pan-genomic "ESKAPE Club members" (see also Table 2). When we entered MDR/XDR, or pan-resistant, and S. aureus or Enterococcus, we invoked few (24 and 6, respectively) references. However, none of those strains discussed in the articles would qualify as pan-resistant or XDR. We propose that the plausible explanation must be collateral sensitivity. The polyclonally spreading pathogens also display a permanent threat but would not cause epidemics. As far as we know, there is no clonally disseminating pan-genomic Gram-positive pathogen species. In addition, we found few references about Gram-positive XDR isolates, although $<5 \%$ of the publications about PDR isolates are cited by PubMed. However, the evidence on pan-genomic isolates contradicts this conclusion. We suppose that there are other unrevealed resistance mechanisms based in the versatility of Gram-positive cell walls, which may provide more general protection to the Gram-positive organisms expressing the respective alleles, but we do not suppose that this kind of resistance could be disseminated globally.

Table 1. Temporal distribution of PubMed cited reviews on MDR-related issues in Gram-negative ESKAPE bacteria.

\begin{tabular}{|c|c|c|c|c|c|c|}
\hline \multicolumn{7}{|c|}{$\begin{array}{l}\text { A. Temporal Distribution of PubMed Cited Reviews on ESBL, Carbapenem, and Colistin Resistance in } \\
\text { Gram-negative (Old List) ESKAPE bacteria }\end{array}$} \\
\hline \multirow{3}{*}{ Questions to PubMed (Entries) } & \multicolumn{6}{|c|}{ Answers (Items): Articles: A, Reviews: R) } \\
\hline & \multicolumn{2}{|c|}{ ALL } & \multirow{2}{*}{$\begin{array}{c}2019 \\
R\end{array}$} & \multirow{2}{*}{$\begin{array}{c}2018 \\
\text { R }\end{array}$} & \multirow{2}{*}{$\begin{array}{c}2009 \\
\text { R } \\
\end{array}$} & \multirow{2}{*}{$\begin{array}{c}2001 \\
\mathbf{R} \\
\end{array}$} \\
\hline & A & $\mathbf{R}$ & & & & \\
\hline Beta-lactams & 130,408 & 9814 & 121 & 325 & 345 & 332 \\
\hline Extended Spectrum Beta-Lactam Resistance (ESBL) & 5906 & 510 & 46 & 64 & 20 & 11 \\
\hline ESBL Klebsiella & 2763 & 192 & 11 & 13 & 10 & 8 \\
\hline ESBL Escherichia coli & 3952 & 191 & 5 & 20 & 12 & 6 \\
\hline ESBL Acinetobacter & 505 & 64 & 5 & 4 & 6 & 1 \\
\hline ESBL Pseudomonas & 853 & 98 & 7 & 8 & 6 & 0 \\
\hline Carbapenems & 17,031 & 1992 & 135 & 193 & 114 & 34 \\
\hline Carbapenem Resistance (CRE) & 11,981 & 1461 & 118 & 164 & 95 & 20 \\
\hline CRE Enterobacteriaceae & 2085 & 344 & 50 & 64 & 7 & 0 \\
\hline CRE Klebsiella & 3067 & 292 & 22 & 42 & 19 & 4 \\
\hline CRE Acinetobacter & 2959 & 334 & 36 & 32 & 23 & 3 \\
\hline CRE Pseudomonas & 3142 & 377 & 28 & 36 & 22 & 5 \\
\hline Colistin & 7027 & 653 & 72 & 78 & 21 & 4 \\
\hline Colistin resistance & 4640 & 509 & 62 & 63 & 18 & 3 \\
\hline mcr colistin resistance & 625 & 39 & 7 & 13 & 0 & 0 \\
\hline Colistin resistance, Enterobacter & 1712 & 150 & 20 & 29 & 2 & 0 \\
\hline Colistin resistance, Klebsiella & 914 & 111 & 12 & 13 & 3 & 0 \\
\hline Colistin resistance, Acinetobacter & 1363 & 185 & 22 & 17 & 9 & 1 \\
\hline Colistin resistance, Pseudomonas & 1123 & 154 & 10 & 14 & 11 & 2 \\
\hline
\end{tabular}


Table 1. Cont.

\begin{tabular}{|c|c|c|c|c|c|c|}
\hline \multicolumn{7}{|c|}{$\begin{array}{l}\text { B. Temporal Distribution of PubMed Cited Reviews on Multidrug- Resistance (MDR), Extended Spectrum (XDR) } \\
\text { Resistance, and Pan-resistance in Clonal and Polyclonal Disseminating Gram-Negative ESKAPE Pathogens }\end{array}$} \\
\hline \multirow{3}{*}{ Questions to PubMed (Entries) } & \multicolumn{6}{|c|}{ Answers (Items): Articles: A, Reviews: R) } \\
\hline & \multicolumn{2}{|c|}{ ALL } & \multirow{2}{*}{$\begin{array}{c}2019 \\
\text { R }\end{array}$} & \multirow{2}{*}{$\begin{array}{c}2018 \\
R\end{array}$} & \multirow{2}{*}{$\begin{array}{c}2009 \\
\text { R }\end{array}$} & \multirow{2}{*}{\begin{tabular}{|c|}
2001 \\
$R$
\end{tabular}} \\
\hline & A & $\mathbf{R}$ & & & & \\
\hline Acinetobacter MDR & 1261 & 174 & 25 & 25 & 10 & 0 \\
\hline Acinetobacter MDR/XDR & 18 & 2 & 0 & 0 & 0 & 0 \\
\hline Acinetobacter Pandrug-resistant & 96 & 23 & 2 & 4 & 2 & 0 \\
\hline Pseudomonas MDR & 1310 & 165 & 19 & 27 & 9 & 2 \\
\hline Pseudomonas MDR/XDR & 25 & 4 & 0 & 1 & 0 & 0 \\
\hline Pseudomonas Pandrug-resistant & 52 & 1 & 1 & 2 & 1 & 0 \\
\hline Klebsiella MDR & 1056 & 100 & 18 & 14 & 4 & 1 \\
\hline Klebsiella MDR/XDR & 9 & 2 & 1 & 1 & 0 & 0 \\
\hline Klebsiella Pandrug-resistant & 48 & 11 & 1 & 1 & 0 & 0 \\
\hline Enterobacter MDR & 272 & 14 & 5 & 1 & 1 & 0 \\
\hline Enterobacter MDR/XDR & 8 & 2 & 1 & 0 & 0 & 0 \\
\hline Enterobacter Pandrug-resistant & 1 & 0 & 0 & 0 & 0 & 0 \\
\hline cephalosporin resistant Enterobacteriaceae MDR & 121 & 12 & 2 & 3 & 0 & 0 \\
\hline cephalosporin resistant Enterobacteriaceae MDR/XDR & 1 & 0 & 0 & 0 & 0 & 0 \\
\hline cephalosporin-resistant Enterobacteriaceae Pandrug-resistant & 0 & 0 & 0 & 0 & 0 & 0 \\
\hline Salmonella typhi MDR & 177 & 23 & 2 & 3 & 1 & 0 \\
\hline Salmonella typhi MDR/XDR & 8 & 1 & 0 & 0 & 1 & 0 \\
\hline Salmonella typhi Pandrug-resistant & 0 & 0 & 0 & 0 & 0 & 0 \\
\hline Escherichia coli MDR & 1721 & 107 & 12 & 12 & 6 & 3 \\
\hline Escherichia coli MDR/XDR & 8 & 1 & 0 & 0 & 0 & 0 \\
\hline Escherichia coli Pandrug-resistant & 24 & 3 & 0 & 0 & 0 & 0 \\
\hline
\end{tabular}

C. Temporal Distribution of PubMed Cited Reviews on Multidrug- Resistance (MDR), Extended Spectrum (XDR) Resistance, and Pan-resistance in Bacteria Recently Scored to the Gram-Negative ESKAPE Pathogens [119]

\begin{tabular}{|c|c|c|c|c|c|c|}
\hline \multirow{3}{*}{ Questions to PubMed (Entries) } & \multicolumn{6}{|c|}{ Evoked Items: Articles: A, Reviews: R) } \\
\hline & \multicolumn{2}{|c|}{ ALL } & \multirow{2}{*}{$\begin{array}{c}2019 \\
\mathbf{R}\end{array}$} & \multirow{2}{*}{$\begin{array}{c}2018 \\
\mathbf{R}\end{array}$} & \multirow{2}{*}{$\begin{array}{c}2009 \\
\mathbf{R}\end{array}$} & \multirow{2}{*}{$\begin{array}{c}2001 \\
R\end{array}$} \\
\hline & A & $\mathbf{R}$ & & & & \\
\hline Helicobacter pylori MDR & 54 & 2 & 0 & 1 & 0 & 0 \\
\hline Helicobacter pylori MDR/XDR & 0 & 0 & 0 & 0 & 0 & 0 \\
\hline Helicobacter pylori Pandrug-resistant & 1 & 1 & 0 & 0 & 0 & 0 \\
\hline clarithromycin-resistant Helicobacter pylori & 316 & 33 & 3 & 5 & 0 & 1 \\
\hline clarithromycin-resistant Helicobacter pylori MDR & 4 & 0 & 0 & 0 & 0 & 0 \\
\hline clarithromycin-resistant Helicobacter pylori MDR/XDR & 0 & 0 & 0 & 0 & 0 & 0 \\
\hline clarithromycin-resistant Helicobacter pylori Pandrug-resistant & 0 & 0 & 0 & 0 & 0 & 0 \\
\hline Campylobacter MDR & 72 & 5 & 0 & 1 & 1 & 0 \\
\hline Campylobacter MDR/XDR & 0 & 0 & 0 & 0 & 0 & 0 \\
\hline Campylobacter Pandrug-resistant & 0 & 0 & 0 & 0 & 0 & 0 \\
\hline fluoroquinolone-resistant Campylobacter & 69 & 10 & 4 & 3 & 2 & 3 \\
\hline fluoroquinolone-resistant Campylobacter MDR & 4 & 0 & 0 & 0 & 0 & 0 \\
\hline fluoroquinolone-resistant Campylobacter MDR/XDR & 0 & 0 & 0 & 0 & 0 & 0 \\
\hline fluoroquinolone-resistant Campylobacter Pandrug-resistant & 0 & 0 & 0 & 0 & 0 & 0 \\
\hline Neisseria gonorrhoeae MDR & 44 & 3 & 0 & 0 & 0 & 0 \\
\hline Neisseria gonorrhoeae MDR/XDR & 0 & 0 & 0 & 0 & 0 & 0 \\
\hline Neisseria gonorrhoeae Pandrug-resistant & 0 & 0 & 0 & 0 & 0 & 0 \\
\hline
\end{tabular}

Legend to Table 1: The number of publications on anti-Gram-negative compounds in beta-lactams is an order of magnitude larger than those publications on carbapenem. The number of publications about CRE is about a half order of magnitude larger than about ESBL and gradually increasing, especially in Enterobacteriaceae. The majority of colistin resistance-related publications appeared in the last decade, but each resistance seems to be a rather permanent, rather than alarming problem, if we consider the number of reviews as an indicator (Table 1A). The publications found by entry on MDR are very high for each ESKAPE Gram-negative pathogen, with Escherichia coli showing a significant but not sharp increase. However, MDR/XDR evoked a significant number of items, only on the clonally distributing ESKAPE pathogens, and few of the others, including E. coli. The entry PDR evoked a significant number of items, only on the clonally distributing ESKAPE pathogens, and few of the others, except for E. coli with 24 items (Table 1B). As for the new "ESKAPE Club members", only one publication reported PDR (in Helicobacter), and none for XDR. However, the entry MDR invoked a significant number of recent publications (Table 1C). 
Table 2. Temporal distribution of PubMed cited reviews on MDR-related issues in Gram-positive ESKAPE bacteria.

\begin{tabular}{|c|c|c|c|c|c|c|}
\hline \multirow[t]{3}{*}{ Questions to PubMed (Entries) } & \multicolumn{6}{|c|}{ Evoked Items: Articles: A, Reviews: R) } \\
\hline & \multicolumn{2}{|c|}{ ALL } & \multirow{2}{*}{$\begin{array}{c}2019 \\
R\end{array}$} & \multirow{2}{*}{$\begin{array}{c}2018 \\
R\end{array}$} & \multirow{2}{*}{$\begin{array}{c}2009 \\
R\end{array}$} & \multirow{2}{*}{$\begin{array}{c}2001 \\
\mathbf{R}\end{array}$} \\
\hline & A & $\mathbf{R}$ & & & & \\
\hline \multicolumn{7}{|c|}{ A. Temporal Distribution of PubMed Cited Reviews on MDR-related issues with MRSA Staphylococcus aureus } \\
\hline S. aureus MRSA & 31,827 & 2098 & 141 & 249 & 384 & 161 \\
\hline S. aureus MRSA Antibiotic Resistance & 15,822 & 2085 & 35 & 83 & 148 & 109 \\
\hline S. aureus Vancomycin Resistance & 6448 & 1119 & 22 & 36 & 73 & 60 \\
\hline S. aureus MRSA VAN-R & 4591 & 885 & 13 & 28 & 50 & 42 \\
\hline S. aureus Daptomycin resistance & 1462 & 319 & 11 & 17 & 26 & 1 \\
\hline S. aureus MRSA DAP-R & 1169 & 264 & 10 & 13 & 18 & 2 \\
\hline S. aureus Carbapenem Resistance & 1189 & 187 & 16 & 19 & 9 & 3 \\
\hline Teixobactin & 69 & 13 & 1 & 4 & 0 & 0 \\
\hline Teixobactin, MRSA & 15 & 3 & 0 & 0 & 0 & 0 \\
\hline S. aureus MDR & 1122 & 119 & 9 & 17 & 9 & 2 \\
\hline MDR/XDR Gram-positive & 21 & 5 & 1 & 2 & 0 & 0 \\
\hline MDR/XDR S. aureus & 3 & 2 & 1 & 1 & 0 & 0 \\
\hline \multicolumn{7}{|c|}{ B. Temporal Distribution of PubMed Cited Reviews on MDR-related Issues in the genus Enterococcus } \\
\hline Enterococcus Antibiotic Resistance & 9167 & 1060 & 26 & 50 & 51 & 51 \\
\hline Enterococcus MDR & 418 & 44 & 6 & 5 & 0 & 2 \\
\hline Enterococcus MDR/XDR & 2 & 2 & 1 & 1 & 0 & 0 \\
\hline Enterococcus methicillin-resistant & 2253 & 453 & 18 & 22 & 23 & 19 \\
\hline Enterococcus Vancomycin Resistance & 5355 & 713 & 55 & 77 & 53 & 58 \\
\hline Enterococcus VRE & 2247 & 274 & 10 & 20 & 6 & 14 \\
\hline E. faecium Vancomycin Resistance & 2635 & 226 & 10 & 12 & 8 & 14 \\
\hline E. faecium VRE & 985 & 83 & 5 & 6 & 2 & 7 \\
\hline E. faecalis Vancomycin Resistance & 1824 & 241 & 6 & 11 & 6 & 4 \\
\hline E. faecalis VRE & 564 & 45 & 1 & 4 & 1 & 3 \\
\hline E. caecum Vancomycin Resistance & 13 & 0 & 0 & 0 & 0 & 0 \\
\hline E. gallinarum Vancomycin Resistance & 278 & 10 & 11 & 2 & 6 & 7 \\
\hline Enterococcus Daptomycin resistance & 584 & 120 & 30 & 42 & 35 & 7 \\
\hline E. faecium Daptomycin resistance & 347 & 47 & 3 & 2 & 4 & 4 \\
\hline E. faecalis Daptomycin resistance & 295 & 33 & 1 & 2 & 2 & 0 \\
\hline E. caecum Daptomycin Resistance & 2 & 0 & 0 & 0 & 0 & 0 \\
\hline E. gallinarum Daptomycin Resistance & 11 & 1 & 0 & 0 & 0 & 0 \\
\hline Enterococcus carbapenem resistance & 524 & 72 & 7 & 5 & 2 & 2 \\
\hline
\end{tabular}

C. Antibiotic Multiresistance (MDR), Extreme Large Spectrum (XDR) Resistance, and Pan-resistance in Gram-Positive ESKAPE Pathogens

\begin{tabular}{lcccccc}
\hline Gram-positive bacteria MDR & 4292 & 542 & 11 & 42 & 34 & 12 \\
Gram-positive bacteria MDR/XDR & 21 & 5 & 1 & 2 & 0 & 0 \\
Gram-positive bacteria PDR & 17 & 6 & 0 & 1 & 0 & 0 \\
S. aureus MDR & 1122 & 119 & 9 & 17 & 9 & 2 \\
S. aureus MDR/XDR & 3 & 2 & 1 & 1 & 0 & 0 \\
S. aureus Pandrug-resistant & 19 & 9 & 0 & 2 & 0 & 0 \\
S. aureus MRSA MDR & 715 & 84 & 6 & 14 & 8 & 1 \\
S. aureus MRSA MDR/XDR & 2 & 2 & 1 & 3 & 0 & 0 \\
S. aureus MRSA Pandrug-resistant & 12 & 5 & 0 & 1 & 0 & 0 \\
Enterococcus MDR & 418 & 44 & 6 & 4 & 0 & 2 \\
Enterococcus MDR/XDR Enterococcus & 3 & 1 & 1 & 0 & 0 & 0 \\
Enterococcus Pandrug-resistant & 9 & 4 & 0 & 1 & 0 & 0 \\
Enterococcus VRE MDR & 92 & 12 & 3 & 4 & 0 & 0 \\
Enterococcus VRE MDR/XDR & 1 & 1 & 1 & 0 & 0 & 0 \\
Enterococcus VRE Pandrug-resistant & 3 & 0 & 0 & 0 & 0 & 0
\end{tabular}

Legend to Table 2: The bulk of the MRSA literature deals with antibiotic resistance. Interestingly, the temporal distributions of VAN-R and DAP-R MRSA publications are almost even, indicating a serious and permanent, but not an alarming, situation. A significant amount of the literature deals with carbapenem resistance in every year, and surprisingly few are about teixobactin in MRSA, as if this antibiotic, which was discovered 4 years ago, would not have been the dreamed for Jolly Joker antibiotic (Table 2A). Like polyclonally disseminating Gram-negative ESKAPE pathogens, despite the large number (1122) of MDR-subjected publications, only 3 items were found with MDR/XDR in a MRSA entry (Table 2C). The trend in Enterococci is rather similar. However, unlike the MRSA literature, the number of MDR articles is dramatically increasing for the Enterococcus literature, especially E. faecium, which seems to be in antibiotic-resistance evolutionary bloom. As far as we know, there is no known clonally disseminating pan-genomic Gram-positive pathogen species, and few references about Gram-positive XDR isolates were found, even though $<5 \%$ of the publications about PDR isolates are cited by PubMed. 
Table 3 demonstrates that literature of the two pangenomic Gram-negatives is the largest, and many of the publications deal with MDR, XDR, and PDR problems. The only significant difference between the two species is that Pseudomonas has a large host range, including plants, while the host range of Acinetobacter is extremely narrow. We did not focus on Klebsiella in this review. Very few of the Acinetobacter and Pseudomonas publications deal with collateral sensitivity, and that is not good news. It probably indicates that this evolutionary mechanism is not working in pangenomic bacteria. It should urgently be experimentally tested.

Table 3. Temporal distribution of antibiotic resistance related PubMed cited reviews on genetics and genomics of the open pan-genomic Gram-negative pathogens Acinetobacter baumannii and Pseudomonas aeruginosa.

\begin{tabular}{ccccccc}
\hline Questions to PubMed (Entries) & \multicolumn{7}{c}{ Evoked Items: Articles: A, Reviews: $\mathbf{R}$} \\
\hline & \multicolumn{2}{c}{ ALL } & $\mathbf{2 0 1 9}$ & $\mathbf{2 0 1 8}$ & $\mathbf{2 0 0 9}$ & $\mathbf{2 0 0 1}$ \\
\cline { 2 - 7 } & $\mathbf{A}$ & $\mathbf{R}$ & $\mathbf{R}$ & $\mathbf{R}$ & $\mathbf{R}$ & $\mathbf{R}$ \\
\hline Acinetobacter & & & & & & \\
Intrinsic resistance & 243 & 46 & 2 & 3 & 2 & 0 \\
Acquired Resistance & 1208 & 243 & 9 & 14 & 16 & 6 \\
Resistance genes & 1808 & 103 & 11 & 10 & 3 & 1 \\
Plasmids, Genomic Islands & 27 & 4 & 0 & 1 & 0 & 0 \\
Antibiotic Resistance mechanisms & 932 & 206 & 14 & 13 & 11 & 2 \\
Antibiotic Resistance, Genome plasticity & 24 & 4 & 0 & 0 & 0 & 0 \\
Horizontal Gene Transfer & 210 & 16 & 0 & 1 & 1 & 0 \\
Pangenome pangenomic & 9 & 1 & 0 & 0 & 0 & 0 \\
Clonal Global Distribution & 16 & 1 & 0 & 0 & 0 & 0 \\
Diseases & 4237 & 530 & 45 & 50 & 36 & 18 \\
Host range & 73 & 9 & 1 & 0 & 0 & 0 \\
Collateral Sensitivity & 5 & 1 & 0 & 0 & 0 & 0 \\
Pseudomonas & & & & & & \\
Intrinsic resistance & 577 & 117 & 8 & 11 & 3 & 4 \\
Acquired Resistance & 2249 & 437 & 25 & 32 & 27 & 12 \\
Resistance genes & 4647 & 233 & 12 & 17 & 4 & 6 \\
Plasmids, Genomic Islands & 39 & 2 & 0 & 0 & 0 & 0 \\
Antibiotic Resistance mechanisms & 2075 & 411 & 16 & 35 & 16 & 10 \\
Resistance, Genome plasticity & 36 & 4 & 1 & 0 & 0 & 0 \\
Horizontal Gene transfer & 512 & 44 & 2 & 3 & 2 & 1 \\
Pangenome & 50 & 4 & 0 & 0 & 0 & 0 \\
Clonal Global Distribution & 6 & 0 & 0 & 0 & 0 & 0 \\
Diseases & 22.950 & 2628 & 92 & 157 & 129 & 04 \\
Host range & 404 & 48 & 2 & 8 & 4 & 1 \\
Collateral Sensitivity & 10 & 1 & 0 & 0 & 0 & 0 \\
\hline
\end{tabular}

\subsection{Pharmaceutical Perspectives}

\subsubsection{Search for Omnipotent ("Jolly Joker") Antibiotics}

We feel the clinching argument for our view of science is as follows. So far, science has produced "cards", including the ace cards" (colistin, daptomycin) for the "card games", but each was "hit" by the respective resistances. "Jolly Jokers" are needed. One "Jolly Joker" (teixobactin) [383] active in Gram-positive bacteria has been identified. So far, no resistance has been noted [388].

\subsubsection{The Perspectives of Antimicrobial Peptide (AMP) Molecules}

The different types of multidrug resistances (MDR, XDR, PDR) are an enormous challenge with clinical, veterinary, and plant-pathogenic significance. This review aimed to give a general view rather than specific perspectives. We are aware that chemotherapeutic tools should always be available, 
ready to combat new pathogens and overcome any new resistance. We are convinced that due to their molecular heterogeneity, structural versatility, and target spectra, the natural antimicrobial peptide (AMP) molecules and synthetic derivatives provide an inexhaustible source of new optimized toolkits capable of combatting new MDR pathogens. Furthermore (as discussed in 6.4.1), both the mobilization patterns, as well as the functional compatibilities with new target bacterial hosts of AMP-resistance genes, and traditional antibiotic-resistance genes, are different.

The AMP research strategy relies on searching for new natural molecules, computer-design and quantitative structure-activity relationships (QSAR), and analysis of derivatives to provide databases for getting descriptor molecules with better pharmacokinetic profiles. Many natural AMPs are primary (ribosome-templated) gene products. Others are or non-ribosomal-templated peptide (NRP) molecules, synthesized enzymatically by multienzyme thiotemplate mechanisms using non-ribosomal peptide synthetases (NRPS) and/or fatty acid synthase (FAS)-related polyketide synthases. Our next review (Fodor et al., in preparation) will provide a useable inventory of AMPs. This includes primary gene products (from mammals, free-living bacteria, plants, plant-bacterium symbiotic associations, and insects) and NRPs. In that review, we intend to discuss the role of natural AMPs in plant innate immune defense mechanisms, especially genetic aspects discovered in Arabidopsis thaliana.

The specificity of the resistance mechanism is based on Microbe-Associated Molecular Patterns (MAMPs). The anti-MDR potential of the large target-spectral NRP-AMPs produced by obligate bacterial symbiotic bacteria (EPB, belonging to the genera Xenorhabdus, Photorhabdus) of entomopathogenic nematodes (EPN, Steinernema, Heterorhabditis species) in vitro is excellent. Their natural role is to provide monoxenic conditions for the respective EPN/EPB symbiotic "couple" in polyxenic (soil, cadaver) environments. They are effective against a large number of both prokaryotic and eukaryotic opportunistic soil microbes, as well as against human, veterinary, and plant-pathogen organisms which they have never encountered in nature (as noted in several labs). They might successfully be applied more efficiently for plant protection as soil ingredients than in clinical practice.

As discussed in Sections 4.2.6, 4.2.7 and 5.1, some NPR-AMPs (vancomycin, daptomycin, teixobactin) were efficient against Gram-positive targets. All but teixobactin has been overcome by resistance. Others (colistin, Sections 3.6 and 3.7) were used against Gram-negative MDR targets, but have also been overcome by resistance. Some drug candidates with unnatural (beta) amino acid substituents are extremely efficient against ESKAPE pathogens [383,391]. Others (ARV-1502) are in clinical studies [402,403].

As discussed in Section 5.2, the proline-rich AMPs (PrAMPs of insect origin and their optimized derivatives) are of a uniquely outstanding medical perspective, especially because they have a larger target spectrum in vivo than in vitro. These data confirm our previous conclusion that the battle between newly appearing representatives of MDR and novel AMPs is permanent and endless.

We note the availability of recently available AMP databases that could be used for modeling. The best ones are as follows: DBAASP (PubMed: 27060142), APD3 (PubMed: 26602694), CAMP (PubMed: 19923233), LAMP (PubMed: 23825543), and dbAMP (PubMed: 30380085), just to mention a few. In addition, Spanig and Heider recently published a review on AMP modeling for diagnostics (PubMed: 30867681), which we referred to as [391].

\subsection{Closing Remark}

Apart from natural reasons (phylogenetic barriers, collateral sensitivity), the profession ability of molecular designers and the availability of abundant natural sources of antimicrobial peptides with structural diversity and heterogeneity can assure the post-antibiotic age will never come. The question is whether nature will, or will not, be able to invent new wedges (resistance) against the new potential "Jolly Jokers" (AMPs).

Supplementary Materials: The following are available online at http://www.mdpi.com/2076-0817/9/7/522/s1. 
Author Contributions: A.F. and L.M. conceived the concept and finalized the manuscript, and separated chapters. References on plant pathogens and related subjects were collected, evaluated, discussed, and selected by Z.K., E.G., and G.S. B.A.A. finalized the list of references. D.V. finalized the Supplementary Materials. L.M., M.G.K., and P.D. coedited. L.F. and L.M. prepared Supplementary Material 1, and J.M. prepared Supplementary Material 4. L.Ö. Jr commented and revised, added information on ARV-1502, and gave a final review. Z.K. and A.F. made the last final shaping of the before submission to Pathogens. Each coauthor saw and edited the manuscript and agreed to its submission. M.G.K. accomplished each of the three revised versions and made the English acceptable. All authors have read and agreed to the published version of the manuscript.

Funding: This research was supported by the 12190-4/2017/ FEKUTSTRAT grant of the Hungarian Ministry of Human Capacities, which generously covered the publication costs. This project was also generously supported by a Fulbright Biological Science Grant (1214102).

Acknowledgments: This manuscript was released as a Pre-Print at preprints.org $>$ life sciences $>$ microbiology $>$ doi:10.20944/preprints201808.0036.v1. We express our thanks to Swam Short (Head of the Library in Ohio State University, Wooster, $\mathrm{OH}$ ) who kindly provided shelter and professional and technical support to accomplish the MS properly. This MS would never have materialized otherwise. Many thanks for professional and unselfish technical help and support of Andrea Máthé-Fodor (Molecular and Cellular Imaging Center, Ohio State University, Wooster, $\mathrm{OH}, \mathrm{USA}$ ) throughout in every stage of the work. The corresponding author wrote it in memoriam of his 102-year-old mother, Éva Varga Boromissza. For the last critical overview of the MS we express our thanks to Ildikó Varga, Veszprém, Hungary.

Conflicts of Interest: The authors declare that the research was conducted in the absence of any commercial or financial relationships that could be construed as a potential conflict of interest. Author László Ötvös Jr. is President of OLPE, LLC, a pharmaceutical consulting firm and inventor of the issued international patent on ARV-1502. He is a senior consultant of Arrevus, Inc., a biotechnology company focusing on the clinical development of ARV-1502 against various bacterial infectious diseases. The remaining authors declare that the research was conducted in the absence of any commercial or financial relationships that could be construed as a potential conflict of interest.

\section{References}

1. Watkins, R.R.; Bonomo, R.A. Overview: Global and local impact of antibiotic resistance. Infect. Dis. Clin. N. Am. 2016, 30, 313-322. [CrossRef]

2. Magiorakos, A.P.; Srinivasan, A.; Carey, R.B.; Carmeli, Y.; Falagas, M.E.; Giske, C.G.; Harbarth, S.; Hindler, J.F.; Kahlmeter, G.; Olsson-Liljequist, B.; et al. Multidrug-resistant, extensively drug-resistant and pandrugresistant bacteria: An international expert proposal for interim standard definitions for acquired resistance. Clin. Microbiol. Infect. 2012, 18, 268-281. [CrossRef]

3. El Zowalaty, M.E.; Al Thani, A.A.; Webster, T.J.; El Zowalaty, A.E.; Schweizer, H.P.; Nasrallah, G.K.; Marei, H.E.; Ashour, H.M. Pseudomonas aeruginosa: Arsenal of resistance mechanisms, decades of changing resistance profiles, and future antimicrobial therapies. Future Microbiol. 2015, 10, 1683-1706. 115. [CrossRef]

4. Imperi, F.; Antunes, L.C.; Blom, J.; Villa, L.; Iacono, M.; Visca, P.; Carattoli, A. The genomics of Acinetobacter baumannii: Insights into genome plasticity, antimicrobial resistance and pathogenicity. IUBMB Life 2011, 63, 1068-1074. [CrossRef]

5. Lean, S.S.; Yeo, C.C. Small, enigmatic plasmids of the nosocomial pathogen, Acinetobacter baumannii: Good, bad, who knows? Front. Microbiol. 2017, 8, 1547. [CrossRef] [PubMed]

6. Morris, F.C.; Dexter, C.; Kostoulias, X.; Uddin, M.I.; Peleg, A.Y. The mechanisms of disease caused by Acinetobacter baumannii. Front. Microbiol. 2019, 10, 1601. [CrossRef]

7. Winsor, G.L.; Griffiths, E.J.; Lo, R.; Dhillon, B.K.; Shay, J.A.; Brinkman, F.S. Enhanced annotations and features for comparing thousands of Pseudomonas genomes in the Pseudomonas genome database. Nucleic Acids Res. 2016, 44, D646-D653. [CrossRef] [PubMed]

8. Ramanathan, B.; Jindal, H.M.; Le, C.F.; Gudimella, R.; Anwar, A.; Razali, R.; Poole-Johnson, J.; Manikam, R.; Sekaran, S.D. Next generation sequencing reveals the antibiotic resistant variants in the genome of Pseudomonas aeruginosa. PLoS ONE 2017, 12, e0182524. [CrossRef] [PubMed]

9. Jeukens, J.; Freschi, L.; Kukavica-Ibrulj, I.; Emond-Rheault, J.G.; Tucker, N.P.; Levesque, R.C. Genomics of antibiotic-resistance prediction in Pseudomonas aeruginosa. Ann. N. Y. Acad. Sci. 2019, 1435, 5-17. [CrossRef] [PubMed]

10. Abraham, E.P.; Chain, E. An enzyme from bacteria able to destroy penicillin. Nature 1940, 146, 837. [CrossRef]

11. Perron, G.G.; Inglis, R.F.; Pennings, P.S.; Cobey, S. Fighting microbial drug resistance: A primer on the role of evolutionary biology in public health. Evol. Appl. 2015, 8, 211-222. [CrossRef] [PubMed] 
12. Ahmad, M.; Khan, A.U. Global economic impact of antibiotic resistance: A review. J. Glob. Antimicrob. Resist. 2019, 19, 313-316. [CrossRef]

13. Talbot, G.H. What is in the pipeline for Gram-negative pathogens? Expert. Rev. Anti. Infect. Ther. 2008, 6, 39-49. [CrossRef] [PubMed]

14. Dötsch, A.; Becker, T.; Pommerenke, C.; Magnowska, Z.; Jansch, L.; Haussler, S. Genome-wide identification of genetic determinants of antimicrobial drug resistance in Pseudomonas aeruginosa. Antimicrob. Agents Chemother. 2009, 53, 2522-2531. [CrossRef]

15. Cantas, L.; Shah, S.Q.A.; Cavaco, L.M.; Manaia, C.; Walsh, F.; Popowska, M.; Garelick, H.; Bürgmann, H.; Sørum, H. A brief multi-disciplinary review on antimicrobial resistance in medicine and its linkage to the global environmental microbiota. Front. Microbiol. 2013, 4, 96. [CrossRef] [PubMed]

16. Exner, M.; Bhattacharya, S.; Christiansen, B.; Gebel, J.; Goroncy-Bermes, P.; Hartemann, P.; Heeg, P.; Ilschner, C.; Kramer, A.; Larson, E.; et al. Antibiotic resistance: What is so special about multidrug-resistant Gram-negative bacteria? GMS Hyg. Infect. Control 2017, 12. [CrossRef]

17. Szmolka, A.; Nagy, B. Multidrug resistant commensal Escherichia coli in animals and its impact for public health. Front. Microbiol. 2013, 4, 258. [CrossRef]

18. Wilk, T.; Szabó, M.; Szmolka, A.; Kiss, J.; Barta, E.; Nagy, T.; Olasz, F.; Nagy, B. Genome sequences of multidrug-resistant Salmonella enterica subsp. enterica serovar infantis strains from broiler chicks in Hungary. Genome Announc. 2016, 4, e01400-16. [CrossRef]

19. Gebreyes, W.A.; Thakur, S. Multidrug-resistant Salmonella enterica serovar München from pigs and humans and potential interserovar transfer of antimicrobial resistance. Antimicrob. Agents Chemother. 2005, 49, 503-511. [CrossRef]

20. Endimiani, A.; Hujer, K.M.; Hujer, A.M.; Bertschy, I.; Rossano, A.; Koch, C.; Gerber, V.; Francey, T.; Bonomo, R.A.; Perreten, V. Acinetobacter baumannii isolates from pets and horses in Switzerland: Molecular characterization and clinical data. J. Antimicrob. Chemother. 2011, 66, 2248-2254. [CrossRef]

21. Moore, A.M.; Patel, S.; Forsberg, K.J.; Wang, B.; Bentley, G.; Razia, Y.; Qin, X.; Tarr, P.I.; Dantas, G. Pediatric fecal microbiota harbor diverse and novel antibiotic resistance genes. PLoS ONE 2013, 8, e78822. [CrossRef] [PubMed]

22. Davis, M.F.; Peterson, A.E.; Julian, K.G.; Greene, W.H.; Price, L.B.; Nelson, K.; Whitener, C.J.; Silbergeld, E.K. Household risk factors for colonization with multidrug-resistant Staphylococcus aureus isolates. PLoS ONE 2013, 8, e54733. [CrossRef] [PubMed]

23. McManus, B.A.; Coleman, D.C.; Deasy, E.C.; Brennan, G.I.; O'Connell, B.; Monecke, S.; Ehricht, R.; Leggett, B.; Leonard, N.; Shore, A.C. Comparative genotypes, Staphylococcal cassette chromosome mec (SCCmec) genes and antimicrobial resistance amongst Staphylococcus epidermidis and Staphylococcus haemolyticus isolates from infections in humans and companion animals. PLoS ONE 2015, 10, e0138079. [CrossRef]

24. Rzewuska, M.; Stefanska, I.; Kizerwetter-Swida, M.; Chrobak-Cmiel, D.; Szczygielska, P.; Lesniak, M.; Binek, M. Characterization of extended-spectrum- $\beta$-Lactamases produced by Escherichia coli strains isolated from dogs in Poland. Polish J. Microbiol. 2015, 64, 285-288. [CrossRef]

25. Schwarz, S.; Johnson, A.P. Transferable resistance to colistin: A new but old threat. J. Antimicrob. Chemother. 2016, 71, 2066-2070. [CrossRef] [PubMed]

26. Schwarz, C.; Gama, L.T.; Belas, A.; Bergström, K.; Beurlet, S.; Briend-Marchal, A.; Broens, E.M.; Costa, M.; Criel, D.; Damborg, P.; et al. European multicenter study on antimicrobial resistance in bacteria isolated from companion animal urinary tract infections. BMC Vet. Res. 2016, 12, 213. [CrossRef]

27. Fodor, A.; Varga, I.; Hevesi, M.; Máthé-Fodor, A.; Racskó, J.; Hogan, J.A. Anti-microbial peptides of Xenorhabdus origin against multidrug resistant plant pathogens. In A Search for Antibacterial Agents; Bobbarala, V., Ed.; Tech Press: Rijeka, Croatia, 2012; pp. 147-195.

28. Załuga, J.; Stragier, P.; Baeyen, S.; Haegeman, A.; Van Vaerenbergh, J.; Maes, M.; De Vos, P. Comparative genome analysis of pathogenic and non-pathogenic Clavibacter strains reveals adaptations to their lifestyle. BMC Genomics 2014, 15, 392. [CrossRef]

29. Förster, H.; McGhee, G.C.; Sundin, G.W.; Adaskaveg, J.E. Characterization of streptomycin resistance in isolates of Erwinia amylovora in California. Phytopathology 2015, 105, 1302-1310. [CrossRef]

30. Gusberti, M.; Klemm, U.; Meier, M.S.; Maurhofer, M.; Hunger-Glaser, I. Fire blight control: The struggle goes on. A comparison of different fire blight control methods in Switzerland with respect to biosafety, efficacy and durability. Int. J. Environ. Res. Public Health 2015, 12, 11422-11447. [CrossRef] 
31. Fodor, A.; Abate, B.A.; Deák, P.; Fodor, L.; Klein, M.G.; Makrai, M.; Muvevi, J.; Vozik, D. An overview of multi-antibiotic resistance in pathogenic bacteria-From selected genetic and evolutionary aspects-A review. Preprint 2018, 2018080036. [CrossRef]

32. Smits, T.H.M.; Duffy, B.; Blom, J.; Ishimaru, C.A.; Stockwell, V.O.; Pantocin, A. A peptide-derived antibiotic involved in biological control by plant-associated Pantoea species. Arch. Microbiol. 2019, 201, 713-722. [CrossRef] [PubMed]

33. Aćimović, S.D.; Zeng, Q.; McGhee, G.C.; Sundin, G.W.; Wise, J.C. Control of fire blight (Erwinia amylovora) on apple trees with trunk-injected plant resistance inducers and antibiotics and assessment of induction of pathogenesis-related protein genes. Front. Plant Sci. 2015, 6, 16. [CrossRef]

34. Stockwell, V.O.; Sundin, G.W.; Jones, A.L. Antibiotic use in plant agriculture. Ann. Rev. Phytopathol. 2002, 40, 443-465. [CrossRef] [PubMed]

35. Stockwell, V.O.; Duffy, B. Use of antibiotics in plant agriculture. Rev. Sci. Tech. 2012, 31, 199-210. [CrossRef] [PubMed]

36. Talbot, G.H.; Bradley, J.; Edwards, J.E., Jr.; Gilbert, D.; Scheld, M.; Bartlett, J.G. Bad bugs need drugs: An update on the development pipeline from the antimicrobial Availability Task Force of the Infectious Diseases Society of America. Clin. Infect. Diseases 2006, 42, 657-668. [CrossRef] [PubMed]

37. Li, X.Z.; Plésiat, P.; Nikaido, H. The challenge of efflux-mediated antibiotic resistance in Gram-negative bacteria. Clin. Microbiol. Rev. 2015, 28, 337-418. [CrossRef] [PubMed]

38. Miller, W.R.; Munita, J.M.; Arias, C.A. Mechanisms of antibiotic resistance in Enterococci. Expert Rev. Anti. Infect. Ther. 2014, 12, 1221-1236. [CrossRef]

39. Miller, W.R.; Murray, B.E.; Rice, L.B.; Arias, C.A. Vancomycin-Resistant Enterococci: Therapeutic Challenges in the 21st Century. Infect. Dis. Clin. N. Am. 2016, 30, 415-439. [CrossRef]

40. Miller, W.R.; Bayer, A.S.; Arias, C.A. Mechanism of action and resistance to daptomycin in Staphylococcus aureus and Enterococci. Cold Spring Harb. Perspect. Med. 2016, 6, a026997. [CrossRef]

41. Khan, A.; Davlieva, M.; Panesso, D.; Rincon, S.; Miller, W.R.; Diaz, L.; Reyes, J.; Cruz, M.R.; Pemberton, O.; Nguyen, A.H.; et al. Antimicrobial sensing coupled with cell membrane remodeling mediates antibiotic resistance and virulence in Enterococcus faecalis. Proc. Natl. Acad. Sci. USA 2019, 116, 26925-26932. [CrossRef] [PubMed]

42. Conly, J.M.; Johnston, B.L. Where are all the new antibiotics? The new antibiotic paradox. Can. J. Infect. Dis. Med. Microbiol. 2005, 16, 159-160. [CrossRef] [PubMed]

43. Lewis, K.; Strandwitz, P. Antibiotics right under our nose. Nature Microbiol. 2016, 535, 501-502. [CrossRef] [PubMed]

44. Stubbings, W.; Labischinski, H. New antibiotics for antibiotic-resistant bacteria. F1000 Biol. Rep. 2009, 1, 40. [CrossRef] [PubMed]

45. Kosikowska, P.; Lesner, A. Antimicrobial peptides (AMPs) as drug candidates: A patent review (2003-2015). Expert Opin. Ther. Pat. 2016, 26, 689-702. [CrossRef] [PubMed]

46. Kang, H.K.; Kim, C.; Seo, C.H.; Park, Y. The therapeutic applications of antimicrobial peptides (AMPs): A patent review. J. Microbiol. 2017, 255, 1-12. [CrossRef] [PubMed]

47. Wright, G.D. The antibiotic resistome: The nexus of chemical and genetic diversity. Nat. Rev. Microbiol. 2007, 5, 175-186. [CrossRef]

48. Pál, C.; Bengtsson-Palme, J.; Kristiansson, E.; Larsson, D.G. The structure and diversity of human, animal and environmental resistomes. Microbiome 2016, 4, 54. [CrossRef]

49. Bryan, B.E. Genetic modifiers of streptomycin resistance in Pneumococcus. J. Bacteriol. 1961, 82, $461-470$. [CrossRef]

50. Hershberg, R. Antibiotic-independent adaptive effects of antibiotic resistance mutations. Trends Genet. 2017, 33, 521-528. [CrossRef]

51. Georghiou, S.B.; Seifert, M.; Catanzaro, D.G.; Garfein, R.S.; Rodwell, T.C. Increased tuberculosis patient mortality associated with Mycobacterium tuberculosis mutations conferring resistance to second-line antituberculous drugs. J. Clin. Microbiol. 2017, 55, 1928-1937. [CrossRef]

52. Feuerriegel, S.; Cox, H.S.; Zarkua, N.; Karimovich, H.A.; Braker, K.; Rüsch-Gerdes, S.; Niemann, S. Sequence analyses of just four genes to detect extensively drug-resistant Mycobacterium tuberculosis strains in multidrug-resistant tuberculosis patients undergoing treatment. Antimicrob. Agents Chemother. 2009, 53, 3353-3356. [CrossRef] [PubMed] 
53. Georghiou, S.B.; Magana, M.; Garfein, R.S.; Catanzaro, D.G.; Catanzaro, A.; Rodwell, T.C. Evaluation of genetic mutations associated with Mycobacterium tuberculosis resistance to amikacin, kanamycin and capreomycin: A systematic review. PLoS ONE 2012, 7, e33275. [CrossRef] [PubMed]

54. Myneedu, V.P.; Singhal, R.; Khayyam, K.U.; Sharma, P.P.; Bhalla, M.; Behera, D.; Sarin, R. First and second line drug resistance among treatment naïve pulmonary tuberculosis patients in a district under Revised National Tuberculosis Control Programme (RNTCP) in New Delhi. J. Epidemiol. Glob. Health 2015, 5, 365-373. [CrossRef]

55. Dookie, N.; Rambaran, S.; Padayatchi, N.; Mahomed, S.; Naidoo, K. Evolution of drug resistance in Mycobacterium tuberculosis: A review on the molecular determinants of resistance and implications for personalized care. J. Antimicrob. Chemother. 2018, 73, 1138-1151. [CrossRef] [PubMed]

56. Tomasz, A.; Albino, A.; Zanati, E. Multiple antibiotic resistance in a bacterium with suppressed autolytic system. Nature 1970, 227, 138-140. [CrossRef] [PubMed]

57. Tiniakow, G.G.; Terentieva, E.L. Cubitus interruptus, a new genovariation of the fourth chromosome of Drosophila melanogaster. Genetics 1933, 18, 117-120. [PubMed]

58. Thompson, J.N., Jr. A test of the influence of isoallelic variation upon a quantitative character. Heredity 1975, 35, 401-406. [CrossRef]

59. Villee, C.A.; Lavin, G.I. The production of phenocopies in Drosophila using visible light and a photodynamic dye. Anat. Rec. 1946, 96, 565. [CrossRef]

60. Ivanovics, G.; Lantos, J. Phenocopy of resistance to phage W in Bacillus anthracis. Acta Microbiol. Acad. Sci. Hung. 1962, 9, 237-246.

61. Ruppé, E.; Cherkaoui, A.; Lazarevic, V.; Emonet, S.; Schrenzel, J.O. Establishing genotype-to-phenotype relationships in bacteria causing hospital-acquired pneumonia: A prelude to the application of clinical metagenomics. Antibiotics 2017, 6, E30. [CrossRef]

62. Arps, P.J.; Winkler, M.E. Structural analysis of the Escherichia coli K-12 hisT operon by using a kanamycin resistance cassette. J. Bacteriol. 1987, 169, 1061-1070. [CrossRef] [PubMed]

63. Domingues, S.; Da Silva, G.J.; Nielsen, K.M. Global dissemination patterns of common gene cassette arrays in class 1 integrons. Microbiology 2015, 161, 1313-1337. [CrossRef] [PubMed]

64. Liu, J.; Chen, D.; Peters, B.M.; Li, L.; Li, B.; Xu, Z.; Shirliff, M.E. Staphylococcal chromosomal cassettes mec (SCCmec): A mobile genetic element in methicillin-resistant Staphylococcus aureus. Microb. Pathol. 2016, 101, 56-67. [CrossRef] [PubMed]

65. Rosdahl, V.T. Localisation of the penicillinase gene in naturally occurring Staphylococcus aureus strains. Acta Pathol. Microbiol. Scand. Ser. B Microbiol. 1985, 93, 383-388. [CrossRef] [PubMed]

66. Rosdahl, V.T.; Rosendal, K. Resistance to cadmium, arsenate and mercury among Danish strains of Staphylococcus aureus isolated from cases of bacteriaemia, 1957-1974. J. Med. Microbiol. 1980, 13, 383-391. [CrossRef]

67. Si, H.; Zhang, W.J.; Chu, S.; Wang, X.M.; Dai, L.; Hua, X.; Dong, Z.; Schwarz, S.; Liu, S. Novel plasmid-borne multidrug resistance gene cluster including lsa (E) from a linezolid-resistant Enterococcus faecium isolate of swine origin. Antimicrob. Agents Chemother. 2015, 59, 7113-7116. [CrossRef]

68. San Millan, A. Evolution of plasmid-mediated antibiotic resistance in the clinical context. Trends Microbiol. 2018, 26, 978-985. [CrossRef]

69. Wein, T.; Hülter, N.F.; Mizrahi, I.; Dagan, T. Emergence of plasmid stability under non-selective conditions maintains antibiotic resistance. Nat. Commun. 2019, 10, 2595. [CrossRef]

70. Tauch, A.; Schlüter, A.; Bischoff, N.; Goesmann, A.; Meyer, F.; Pühler, A. The 79,370-bp conjugative plasmid pB4 consists of an IncP-1beta backbone loaded with a chromate resistance transposon, the strA-strB streptomycin resistance gene pair, the oxacillinase gene bla(NPS-1), and a tripartite antibiotic efflux system of the resistance-nodulation-division family. Mol. Genet. Genom. 2003, 268, 570-584.

71. Poey, M.E.; Azpiroz, M.F.; Laviña, M. On sulfonamide resistance, sul genes, class 1 integrons and their horizontal transfer in Escherichia coli. Microb. Pathog. 2019, 135, 103611. [CrossRef] [PubMed]

72. Watanabe, T.; Ogata, C.; Sato, S. Episome-mediated transfer of drug resistance in Enterobacteriaceae VIII. J. Bacteriol. 1964, 88, 922-928. [CrossRef]

73. Soufi, L.; Abbassi, M.S.; Sáenz, Y.; Vinué, L.; Somalo, S.; Zarazaga, M.; Abbas, A.; Dbaya, R.; Khanfir, L.; Ben Hassen, A.; et al. Prevalence and diversity of integrons and associated resistance genes in Escherichia coli isolates from poultry meat in Tunisia. Foodborne Pathog. Dis. 2009, 6, 1067-1073. [CrossRef] [PubMed] 
74. Salyers, A.A.; Shoemaker, N.B. Resistance gene transfer in anaerobes: New insights, new problems. Clin. Infect. Dis. 1996, 23, S36-S43. [CrossRef] [PubMed]

75. Butaye, P.; Cloeckaert, A.; Schwarz, S. Mobile genes coding for efflux-mediated antimicrobial resistance in Gram-positive and Gram-negative bacteria. Int. J. Antimicrob. Agents 2003, 22, 205-210. [CrossRef]

76. Poirel, L.; Bonnin, R.A.; Nordmann, P. Genetic basis of antibiotic resistance in pathogenic Acinetobacter species. IUBMB Life 2011, 63, 1061-1067. [CrossRef]

77. Wendlandt, S.; Shen, J.; Kadlec, K.; Wang, Y.; Li, B.; Zhang, W.J.; Feßler, A.T.; Wu, C.; Schwarz, S. Multidrug resistance genes in staphylococci from animals that confer resistance to critically and highly important antimicrobial agents in human medicine. Trends Microbiol. 2015, 23, 44-54. [CrossRef]

78. Navon-Venezia, S.; Kondratyeva, K.; Carattoli, A. Klebsiella pneumoniae: A major worldwide source and shuttle for antibiotic resistance. FEMS Microbiol. Rev. 2017, 41, 252-275. [CrossRef]

79. Partridge, S.R.; Kwong, S.M.; Firth, N.; Jensen, S.O. Mobile genetic elements associated with antimicrobial resistance. Clin. Microbiol. Rev. 2018, 31, e00088-17. [CrossRef]

80. García-Solache, M.; Lebreton, F.; McLaughlin, R.E.; Whiteaker, J.D.; Gilmore, M.S.; Rice, L.B. Homologous recombination within large chromosomal regions facilitates acquisition of $\beta$-lactam and vancomycin resistance in Enterococcus faecium. Antimicrob. Agents Chemother. 2016, 60, 5777-5786. [CrossRef]

81. Shin, J.E.; Lin, C.; Lim, H.N. Horizontal transfer of DNA methylation patterns into bacterial chromosomes. Nucleic Acids Res. 2016, 44, 4460-4471. [CrossRef]

82. Heuer, H.; Smalla, K. Horizontal gene transfer between bacteria. Environ. Biosafety Res. 2007, 6, 3-13. [CrossRef] [PubMed]

83. Broaders, E.; Gahan, G.M.; Marchesi, J.R. Mobile genetic elements of the human gastrointestinal tract. Potential for spread of antibiotic resistance genes. Gut Microbes 2013, 4, 271-280. [CrossRef] [PubMed]

84. Sutherland, R.; Rolinson, G.N. Characteristics of methicillin-resistant Staphylococci. J. Bacteriol. 1964, 87, 887-899. [CrossRef]

85. Arzanlou, M.; Chai, W.C.; Venter, H. Intrinsic, adaptive and acquired antimicrobial resistance in Gram-negative bacteria. Essays Biochem. 2017, 61, 49-59. [PubMed]

86. Dalbadie-McFarland, G.; Neitzel, J.J.; Richards, J.H. Active-site mutants of beta-lactamase: Use of an inactive double mutant to study requirements for catalysis. Biochemistry 1986, 25, 332-338. [CrossRef] [PubMed]

87. Chang, Y.H.; Labgold, M.R.; Richards, J.H. Altering enzymatic activity: Recruitment of carboxypeptidase activity into an RTEM beta-lactamase/penicillin-binding protein 5 chimera. Proc. Natl. Acad Sci. USA 1990, 87, 2823-2827. [CrossRef]

88. Yan, Y.H.; Li, G.; Li, G.B. Principles and current strategies targeting metallo- $\beta$-lactamase mediated antibacterial resistance. Med. Res. Rev 2020, in press. [CrossRef]

89. Baltz, R.H. Spontaneous and induced mutations to rifampicin, streptomycin and spectinomycin resistances in actinomycetes: Mutagenic mechanisms and applications for strain improvement. J. Antibiot. 2014, 67, 619-624. [CrossRef]

90. Behmard, E.; Najafi, A.; Ahmadi, A. Understanding the resistance mechanism of penicillin binding protein 1a mutant against cefotaxime using molecular dynamic simulation. J. Biomol. Struct. Dyn. 2019, 37, 741-749. [CrossRef]

91. Poole, K. Multidrug efflux pumps and antimicrobial resistance in Pseudomonas aeruginosa and related organisms. J. Mol. Microbiol. Biotechnol. 2001, 3, 255-264.

92. Poole, K. Efflux-mediated multiresistance in Gram-negative bacteria. Clin. Microbiol. Infect. 2004, 10, $12-26$. [CrossRef] [PubMed]

93. Hernando-Amado, S.; Blanco, P.; Alcalde-Rico, M.; Corona, F.; Reales-Calderón, J.A.; Sánchez, M.B.; Martínez, J.L. Multidrug efflux pumps as main players in intrinsic and acquired resistance to antimicrobials. Drug Resist. Update 2016, 28, 13-27. [CrossRef]

94. Du, D.; Wang-Kan, X.; Neuberger, A.; van Veen, H.W.; Pos, K.M.; Piddock, L.J.V.; Luisi, B.F. Multidrug efflux pumps: Structure, function and regulation. Nat. Rev. Microbiol. 2018, 16, 523-539. [CrossRef] [PubMed]

95. Ochman, H.; Lawrence, J.G.; Groisman, E.A. Lateral gene transfer and the nature of bacterial innovation. Nature 2000, 405, 299-304. [CrossRef]

96. Juhas, M. Horizontal gene transfer in human pathogens. Crit. Rev. Microbiol. 2015, 41, 101-108. [CrossRef] [PubMed] 
97. Soucy, S.M.; Huang, J.; Gogarten, J.P. Horizontal gene transfer: Building the web of life. Nat. Rev. Genet. 2015, 16, 472-482. [CrossRef]

98. Fullmer, M.S.; Ouellette, M.; Louyakis, A.S.; Papke, R.T.; Gogarten, J.P. The Patchy Distribution of Restriction-Modification System Genes and the Conservation of Orphan Methyltransferases in Halobacteria. Genes 2019, 10, 233. [CrossRef] [PubMed]

99. Zeng, X.; Lin, J. Factors influencing horizontal gene transfer in the intestine. Anim. Health Res. Rev. 2017, 18, 153-159. [CrossRef]

100. Lerminiaux, N.A.; Cameron, A.D.S. Horizontal transfer of antibiotic resistance genes in clinical environments. J. Microbiol. 2019, 65, 34-44. [CrossRef]

101. Van Schaik, W.; Top, J.; Riley, D.R.; Boekhorst, J.; Vrijenhoek, J.E.; Schapendonk, C.M.; Hendrickx, A.P.; Nijman, I.J.; Bonten, M.J.; Tettelin, H.; et al. Pyrosequencing-based comparative genome analysis of the nosocomial pathogen Enterococcus faecium and identification of a large transferable pathogenicity island. BMC Genom. 2010, 11, 239. [CrossRef]

102. Coombs, J.M. Potential for horizontal gene transfer in microbial communities of the terrestrial subsurface. Methods Mol. Biol. 2009, 532, 413-433. [PubMed]

103. Tyrrell, C.; .Burgess, C.M.; Brennan, F.P.; Walsh, F. Antibiotic resistance in grass and soil. Biochem Soc. Trans. 2019, 47, 477-486. [CrossRef] [PubMed]

104. Giordano, C.; Barnini, S.; Tsioutis, C.; Chlebowicz, M.A.; Scoulica, E.V.; Gikas, A.; Rossen, J.W.; Friedrich, A.W.; Bathoorn, E. Expansion of KPC-producing Klebsiella pneumoniae with various mgrB mutations giving rise to colistin resistance: The role of ISL3 on plasmids. Int. J. Antimicrob. Agents 2018, 51, 260-265. [CrossRef] [PubMed]

105. Scoulica, E.V.; Neonakis, I.K.; Gikas, A.I.; Tselentis, Y.J. Spread of bla (VIM-1)-producing E. coli in a university hospital in Greece. Genetic analysis of the integron carrying the bla (VIM-1) metallo-beta-lactamase gene. Diagn. Microbiol. Infect. Dis. 2004, 48, 167-172. [CrossRef] [PubMed]

106. Gray, T.A.; Derbyshire, K.M. Blending genomes: Distributive conjugal transfer in mycobacteria, a sexier form of HGT. Mol. Microbiol. 2018, 108, 601-613. [CrossRef] [PubMed]

107. Pendleton, J.N.; Gorman, S.P.; Gilmore, B.F. Clinical relevance of the ESKAPE pathogens. Expert Rev. Anti. Infect. Ther. 2013, 11, 297-308. [CrossRef]

108. Schwaber, M.J.; Navon-Venezia, S.; Schwartz, D.; Carmeli, Y. High levels of antimicrobial coresistance among extended-spectrum- $\beta$-lactamase-producing Enterobacteriaceae. Antimicrob. Agents Chemother. 2005, 49, 2137-2139. [CrossRef]

109. Rice, L.B. Federal funding for the study of antimicrobial resistance in nosocomial pathogens: "No ESKAPE". J. Infect. Dis. 2008, 197, 1079-1081. [CrossRef]

110. Boucher, H.W.; Talbot, G.H.; Bradley, J.S.; Edwards, J.E.; Gilbert, D.; Rice, L.B.; Scheld, M.; Spellberg, B.; Bartlett, J. Bad bugs, no drugs: No ESCAPE! An Update from the Infectious Diseases Society of America. Clin. Infec. Dis. 2009, 48,1-12. [CrossRef]

111. Rice, L.B. Progress and challenges in implementing the research on ESKAPE pathogens. Infect. Control. Hosp. Epidemiol. 2010, 1, S7-S10. [CrossRef]

112. Schwaber, M.J.; Carmeli, Y. An ongoing national intervention to contain the spread of carbapenem-resistant Enterobacteriaceae. Clin. Infect. Dis. 2014, 58, 697-703. 426. [CrossRef] [PubMed]

113. Sandiumenge, A.; Lisboa, T.; Gomez, F.; Hernandez, P.; Canadell, L.; Rello, J. Effect of antibiotic diversity on ventilator-associated pneumonia caused by ESKAPE organisms. Chest 2011, 140, 643-651. [CrossRef] [PubMed]

114. Penes, N.O.; Muntean, A.A.; Moisoiu, A.; Muntean, M.M.; Chirca, A.; Bogdan, M.A.; Popa, M.I. An overview of resistance profiles ESKAPE pathogens from 2010-2015 in a tertiary respiratory center in Romania. Rom. J. Morphol. Embryol. 2017, 58, 909-922. [PubMed]

115. Azzopardi, E.A.; Azzopardi, S.M.; Boyce, D.E.; Dickson, W.A. Emerging gram-negative infections in burn wounds. J. Burn Care Res. 2011, 32, 570-576. [CrossRef]

116. Navidinia, M. The clinical importance of emerging ESKAPE pathogens in nosocomial infections. J. Paramed. Sci. 2016, 7, 2008-4978.

117. Mulani, M.S.; Kamble, E.E.; Kumkar, S.N.; Tawre, M.S.; Pardesi, K.R. Emerging strategies to combat ESKAPE pathogens in the era of antimicrobial resistance: A Review. Front. Microbiol. 2019, 10, 539. [CrossRef] 
118. Bodro, M.; Gudiol, C.; Garcia-Vidal, C.; Tubau, F.; Contra, A.; Boix, L.; Domingo-Domenech, E.; Calvo, M.; Carratalà, J. Epidemiology, antibiotic therapy and outcomes of bacteremia caused by drug-resistant ESKAPE pathogens in cancer patients. Support Care Cancer 2014, 22, 603-610. [CrossRef]

119. Tacconelli, E.; Carrara, E.; Savoldi, A.; Harbarth, S.; Mendelson, M.; Monnet, D.L.; Pulcini, C.; Kahlmeter, G.; Kluytmans, J.; Carmeli, Y.; et al. Discovery, research, and development of new antibiotics: The WHO priority list of antibiotic-resistant bacteria and tuberculosis. Lancet Infect. Dis. 2018, 18, 318-327. [CrossRef]

120. Santajit, S.; Indrawattana, N. Mechanisms of antimicrobial resistance in ESKAPE pathogens. Biomed. Res. Int. 2016, 2016, 2475067. [CrossRef]

121. Horne, D.; Tomasz, A. Tolerant response of Streptococcus sanguis to beta-lactams and other cell wall inhibitors. Antimicrob. Agents Chemother. 1977, 11, 888-896. [CrossRef]

122. Tomasz, A. Penicillin-binding proteins and the antibacterial effectiveness of beta-lactam antibiotics. Rev. Infect. Dis. 1986, 8, S260-S278. [CrossRef]

123. Quinn, J.P. Clinical significance of extended-spectrum beta-lactamases. Eur. J. Clin. Microbiol. Infect. Dis. 1994, 13, S39-S42. [CrossRef] [PubMed]

124. McDanel, J.; Schweizer, M.; Crabb, V.; Nelson, R.; Samore, M.; Khader, K.; Blevins, A.E.; Diekema, D.; Chiang, H.Y.; Nair, R.; et al. Incidence of extended-spectrum $\beta$-lactamase (ESBL)-producing Escherichia coli and Klebsiella infections in the United States: A systematic literature review. Infect. Control. Hosp. Epidemiol. 2017, 38, 1209-1215. [CrossRef] [PubMed]

125. Flokas, M.E.; Alevizakos, M.; Shehadeh, F.; Andreatos, N.; Mylonakis, E. Extended-spectrum $\beta$-lactamaseproducing Enterobacteriaceae colonisation in long-term care facilities: A systematic review and meta-analysis. Int. J. Antimicrob. Agents 2017, 50, 649-656. [CrossRef]

126. Dame-Korevaar, A.; Fischer, E.A.J.; van der Goot, J.; Stegeman, A.; Mevius, D. Transmission routes of ESBL/pAmpC producing bacteria in the broiler production pyramid, a literature review. Prev. Vet. Med. 2019, 162, 136-150. [CrossRef] [PubMed]

127. Pitout, J.D. Multiresistant Enterobacteriaceae: New threat of an old problem. Expert Rev. Anti. Infect. Ther. 2008, 6, 657-669. [CrossRef] [PubMed]

128. Sacco, E.; Cortes, M.; Josseaume, N.; Bouchier, C.; Dubée, V.; Hugonnet, J.E.; Mainardi, J.L.; Rice, L.B.; Arthur, M. Mutation landscape of acquired cross-resistance to glycopeptide and $\beta$-lactam antibiotics in Enterococcus faecium. Antimicrob. Agents Chemother. 2015, 59, 5306-5315. [CrossRef]

129. Tiwari, S.; Jamal, S.B.; Hassan, S.S.; Carvalho, P.V.; Almeida, S.; Barh, D.; Ghosh, P.; Silva, A.; Castro, T.L.; Azevedo, V. Two-component signal transduction systems of pathogenic bacteria as targets for antimicrobial therapy: An overview. Front. Microbiol. 2017, 8, 1878. [CrossRef]

130. Spengler, G.; Kincses, A.; Gajdács, M.; Amaral, L. New roads leading to old destinations: Efflux pumps as targets to reverse multidrug resistance in bacteria. Molecules 2017, 22, E468. [CrossRef]

131. Schmutzhard, E.; Williams, K.J.; Vukmirovits, G.; Chmelik, V.; Pfausler, B.; Featherstone, A. The Meropenem Meningitis Study Group 1995: A randomized comparison of meropenem with cefotaxime or ceftriaxone for the treatment of bacterial meningitis in adults. J. Antimicrobiol. Chemother. 1995, 36, 85-97. [CrossRef]

132. Almeida, M.V.A.; Cangussú, Í.M.; Carvalho, A.L.S.; Brito, I.L.P.; Costa, R.A. Drug resistance, AmpC- $\beta$-lactamase and extended-spectrum $\beta$-lactamase-producing Enterobacteriaceae isolated from fish and shrimp. Rev. Inst. Med. Trop. Sao Paulo 2017, 59, e70. [CrossRef]

133. Brewer, N.S.; Hellinger, W.C. The monobactams. Mayo Clin. Proc. 1991, 66, 1152-1157. [CrossRef]

134. Jain, P.; Roy, S.; Viswanathan, R.; Basu, S.; Singh, A.K.; Dutta, S. Concurrent and transferable resistance to extended-spectrum cephalosporins, monobactam and fluoroquinolone in a Salmonella enterica serovar Worthington blood isolate from a neonate in Kolkata, India. Int. J. Antimicrob. Agents 2013, 41, 494-495. [CrossRef] [PubMed]

135. Ramsey, C.; MacGowan, A.P. A review of the pharmacokinetics and pharmacodynamics of aztreonam. J. Antimicrob. Chemother. 2016, 71, 2704-2712. [CrossRef] [PubMed]

136. Wright, A.J.; Wilkowske, C.J. The penicillins. Mayo Clin. Proc. 1987, 62, 806-820. [CrossRef]

137. Adnan, S.; Paterson, D.L.; Lipman, J.; Roberts, J.A. Ampicillin/sulbactam: Its potential use in treating infections in critically ill patients. Int. J. Antimicrob. Agents 2013, 42, 384-389. [CrossRef]

138. Chen, C.W.; Ming, C.C.; Ma, C.J.; Shan, Y.S.; Yeh, Y.S.; Wang, J.Y. Prospective, randomized, study of ampicillin-sulbactam versus moxifloxacin monotherapy for the treatment of community-acquired complicated intra-abdominal infections. Surg. Infect. 2013, 4, 389-396. [CrossRef] 
139. Housman, S.T.; Hagihara, M.; Nicolau, D.P.; Kuti, J.L. In vitro pharmacodynamics of human-simulated exposures of ampicillin/sulbactam, doripenem and tigecycline alone and in combination against multidrug-resistant Acinetobacter baumannii. J. Antimicrob. Chemother. 2013, 8, 2296-2304. [CrossRef]

140. Yokoyama, Y.; Matsumoto, K.; Ikawa, K.; Watanabe, E.; Yamamoto, H.; Imoto, Y.; Morikawa, N.; Takeda, Y. The pharmacokinetics of ampicillin-sulbactam in anuric patients: Dosing optimization for prophylaxis during cardiovascular surgery. Int. J. Clin. Pharm. 2016, 38, 771-775. [CrossRef]

141. Hoogkamp-Korstanje, J.A.; Westerdaal, N. Activity and synergy of ureido penicillins and aminoglycosides against Pseudomonas aeruginosa. Infection 1982, 10, S257-S261. [CrossRef]

142. Giamarellou, H.; Antoniadou, A. Antipseudomonal antibiotics. Med. Clin. N. Am. 2001, 85, 19-42. [CrossRef]

143. Butterfield, J.M.; Lodise, T.P.; Beegle, S.; Rosen, J.; Farkas, J.; Pai, M.P. Pharmacokinetics and pharmacodynamics of extended-infusion piperacillin/tazobactam in adult patients with cystic fibrosis-related acute pulmonary exacerbations. J. Antimicrob. Chemother. 2014, 9, 176-180. [CrossRef]

144. Lee, J.; Oh, C.E.; Choi, E.H.; Lee, H.J. The impact of the increased use of piperacillin/ tazobactam on the selection of antibiotic resistance among invasive Escherichia coli and Klebsiella pneumoniae isolates. Int. J. Infect. Dis. 2013, 17, e638-e643. [CrossRef] [PubMed]

145. Shubert, C.; Slaughter, J.; Creely, D.; van Belkum, A.; Gayral, J.P.; Dunne, W.M.; Zambardi, G.; Shortridge, D. Population analysis of Escherichia coli isolates with discordant resistance levels by piperacillin-tazobactam broth microdilution and agar dilution testing. Antimicrob. Agents Chemother. 2014, 58, 1779-1781. [CrossRef] [PubMed]

146. Nichols, K.; Chung, E.K.; Knoderer, C.A.; Buenger, L.E.; Healy, D.P.; Dees, J.; Crumby, A.S.; Kays, M.B. Population pharmacokinetics and pharmacodynamics of extended-infusion piperacillin and tazobactam in critically ill children. Antimicrob. Agents Chemother. 2016, 60, 522-531. [CrossRef] [PubMed]

147. Rahbar, M.; Van de Velde, S.; Eslami, P.; Mardani, M. Activity of temocillin and comparators against urinary Escherichia coli and Klebsiella pneumoniae from Iran. Eur. J. Clin. Microbiol. Infect. Dis. 2020, in press.

148. Mullins, B.P.; Kramer, C.J.; Bartel, B.J.; Catlin, J.S.; Gilder, R.E. Comparison of the nephrotoxicity of vancomycin in combination with cefepime, meropenem, or piperacillin/tazobactam: A prospective, multicenter study. Ann. Pharmacother. 2018, 52, 639-644. [CrossRef]

149. Giacobbe, D.R.; Bassetti, M.; De Rosa, F.G.; Del Bono, V.; Grossi, P.A.; Menichetti, F.; Pea, F.; Rossolini, G.M.; Tumbarello, M.; Viale, P.; et al. ISGRI-SITA (Italian Study Group on Resistant Infections of the Società Italiana Terapia Antinfettiva). Ceftolozane/tazobactam: Place in therapy. Expert Rev. Anti. Infect. Ther. 2018, 16, 307-320. [CrossRef]

150. Zhanel, G.G.; Wiebe, R.; Dilay, L.; Thomson, K.; Rubinstein, E.; Hoban, D.J.; Noreddin, A.M.; Karlowsky, J.A. Comparative review of the carbapenems. Drugs 2007, 67, 1027-1052. [CrossRef]

151. Zhanel, G.G.; Lawrence, C.K.; Adam, H.; Schweizer, F.; Zelenitsky, S.; Zhanel, M.; Lagacé-Wiens, P.R.S.; Walkty, A.; Denisuik, A.; Golden, A.; et al. Imipenem-Relebactam and Meropenem-Vaborbactam: Two novel carbapenem- $\beta$-lactamase inhibitor combinations. Drugs 2018, 78, 65-98. [CrossRef]

152. Mashni, O.; Nazer, L.; Le, J. Critical review of double-carbapenem therapy for the treatment of carbapenemase-producing Klebsiella pneumonia. Ann. Pharmacother. 2019, 53, 70-81. [CrossRef] [PubMed]

153. Abuhussain, S.S.A.; Sutherland, C.A.; Nicolau, D. In vitro potency of antipseudomonal $\beta$-lactams against blood and respiratory isolates of P. aeruginosa collected from US hospitals. J. Thorac. Dis. 2019, 11, 1896-1902. [CrossRef] [PubMed]

154. Breilh, D.; Texier-Maugein, J.; Allaouchiche, B.; Saux, M.C.; Boselli, E. Carbapenems. J. Chemother. 2013, 25, 1-17. [CrossRef] [PubMed]

155. Papp-Wallace, K.; Endimiani, A.; Magdalena, A.; Taracila, M.A.; Bonomo, R.A. Carbapenems: Past, present, and future. Antimicrob. Agents Chemother. 2011, 55, 4943-4960. [CrossRef] [PubMed]

156. Paczkowska, M.; Garbacki, P.; Zalewski, P.; Talaczyńska, A.; Cielecka-Piontek, J. Meropenem-therapeutic recommendation after twenty years of presence on pharmaceutical market. Postepy Hig. Med. Dosw. 2014, 68, 441-445. [CrossRef]

157. Wong, G.; Farkas, A.; Sussman, R.; Daroczi, G.; Hope, W.W.; Lipman, J.; Roberts, J.A. Comparison of the accuracy and precision of pharmacokinetic equations to predict free meropenem concentrations in critically ill patients. Antimicrob. Agents Chemother. 2015, 59, 1411-1417. [CrossRef]

158. Gupta, N.; Limbago, B.M.; Patel, J.B.; Kallen, A.J. Carbapenem-resistant Enterobacteriaceae: Epidemiology and prevention. Clin. Infect. Dis. 2011, 53, 60-67. [CrossRef]

159. Wilson, A.P.R. Sparing carbapenem usage. J. Antimicrob. Chemother. 2017, 72, 2410-2417. [CrossRef] 
160. Beigverdi, R.; Sattari-Maraji, A.; Emaneini, M.; Jabalameli, F. Status of carbapenem-resistant Acinetobacter baumannii harboring carbapenemase: First systematic review and meta-analysis from Iran. Infect. Genet. Evol. 2019, 73, 433-443. [CrossRef]

161. Turton, J.F.; Woodford, N.; Glover, J.; Yarde, S.; Kaufmann, M.E.; Pitt, T.L. Identification of Acinetobacter baumannii by detection of the blaOXA-51-like Carbapenemase gene intrinsic to this species. J. Clin. Microbiol. 2006, 44, 2974-2976. [CrossRef]

162. Turton, J.F.F.; Baddal, B.; Perry, C. Use of the accessory genome for characterization and typing of Acinetobacter baumannii. J. Clin. Microbiol. 2011, 49, 1260-1266. [CrossRef] [PubMed]

163. Kobs, V.C.; Ferreira, J.A.; Bobrowicz, T.A.; Ferreira, L.E.; Deglmann, R.C.; Westphal, G.A.; França, P.H.C.D. The role of the genetic elements bla oxa and IS Aba 1 in the Acinetobacter calcoaceticus-Acinetobacter baumannii complex in carbapenem resistance in the hospital setting. Rev. Soc. Bras. Med. Trop. 2016, 49, 433-440. [CrossRef] [PubMed]

164. Maurya, A.P.; Dhar, D.; Basumatary, M.K.; Paul, D.; Ingti, B.; Choudhury, D.; Talukdar, A.D.; Chakravarty, A.; Mishra, S.; Bhattacharjee, A. Expansion of highly stable bla OXA-10 $\beta$-lactamase family within diverse host range among nosocomial isolates of Gram-negative bacilli within a tertiary referral hospital of Northeast India. BMC Res. Notes 2017, 10, 145. [CrossRef] [PubMed]

165. Yazdansetad, S.; Najari, E.; Ghaemi, E.A.; Javid, N.; Hashemi, A.; Ardebili, A. Carbapenem-resistant Acinetobacter baumannii isolates carrying blaOXA genes with upstream ISAba1: First report of a novel OXA subclass from Iran. J. Glob. Antimicrob. Resist. 2019, 18, 95-99. [CrossRef] [PubMed]

166. Noval, M.; Banoub, M.; Claeys, K.C.; Heil, E. The battle is on: New beta-lactams for the treatment of multidrug-resistant gram-negative organisms. Curr. Infect. Dis. Rep. 2020, 22, 1. [CrossRef]

167. Mugnier, M.D.; Poirel, L.; Naas, T.; Nordmann, P. Worldwide dissemination of the (blaOXA-23) carbapenemase gene of Acinetobacter baumannii. Emerg. Infect. Dis. 2010, 16, 35-40. [CrossRef]

168. Effah, C.Y.; Sun, T.; Liu, S.; Wu, Y. Klebsiella pneumoniae: An increasing threat to public health. Ann. Clin. Microbiol. Antimicrob. 2020, 19, 1. [CrossRef]

169. Singh, A.R. Science, Names Giving and Names Calling: Change NDM-1 to PCM. Mens Sana Monogr. 2011, 9 , 294-319. [CrossRef]

170. Pittalis, S.; Ferarro, F.; Puro, V. NDM-1: The superbug? Infez. Med. 2011, 19, 224-234. (In Italian)

171. Qu, H.; Wang, X.; Ni, Y.; Liu, J.; Tan, R.; Huang, J.; Li, L.; Sun, J. NDM-1-producing Enterobacteriaceae in a teaching hospital in Shanghai, China: IncX3-type plasmids may contribute to the dissemination of blaNDM-1. Int. J. Infect. Dis. 2015, 34, 8-13. [CrossRef]

172. Greninger, A.L.; Chorny, I.; Knowles, S.; Ng, V.L.; Chaturvedi, V. Draft genome ssequences of four NDM-1-producing Klebsiella pneumoniae strains from a health care nacility in Northern California. Genome Announc. 2015, 3, e00421-15. [CrossRef] [PubMed]

173. Hamzan, N.; Yean, C.Y.; Rahman, R.A.; Hasan, H.; Rahman, Z.A. Detection of blaIMP4 and blaNDM1 harboring Klebsiella pneumoniae isolates in a university hospital in Malaysia. Emerg. Health Threats J. 2015, 8, 26011. [CrossRef] [PubMed]

174. Schuelter-Trevisol, F.; Schmitt, G.J.; Araújo, J.M.D.; Souza, L.B.D.; Nazário, J.G.; Januário, R.L.; Mello, R.S.D.; Trevisol, D.J. New Delhi metallo-beta-lactamase-1-producing Acinetobacter spp. infection: Report of a survivor. Rev. Soc. Bras. Med. Trop. 2016, 49, 130-134. [CrossRef]

175. Kazmierczak, K.M.; Rabine, S.; Hackel, M.; McLaughlin, R.E.; Biedenbach, D.J.; Bouchillon, S.K.; Sahm, D.F.; Bradford, P.A. Multiyear, multinational survey of the incidence and global distribution of metallo- $\beta$-lactamase-producing Enterobacteriaceae and Pseudomonas aeruginosa. Antimicrob. Agents Chemother. 2016, 60, 1067-1078. [CrossRef] [PubMed]

176. Zaman, T.U.; Alrodayyan, M.; Albladi, M.; Aldrees, M.; Siddique, M.I.; Aljohani, S.; Balkhy, H.H. Clonal diversity and genetic profiling of antibiotic resistance among multidrug/carbapenem-resistant Klebsiella pneumoniae isolates from a tertiary care hospital in Saudi Arabia. BMC Infect. Dis. 2018, 18, 205. [CrossRef] [PubMed]

177. Ortega, A.; Sáez, D.; Bautista, V.; Fernández-Romero, S.; Lara, N.; Aracil, B.; Pérez-Vázquez, M.; Campos, J.; Oteo, J.; Aznar, J.E. Spanish Collaborating Group for the Antibiotic Resistance Surveillance Programme: Carbapenemase-producing Escherichia coli is becoming more prevalent in Spain mainly because of the polyclonal dissemination of OXA-48. J. Antimicrob. Chemother. 2016, 71, 2131-2138. [CrossRef] 
178. Çicek, A.Ç.; Düzgün, A.Ö.; Saral, A.; Kayman, T.; Çİzmecİ, Z.; Balcı, P.Ö.; Dal, T.; Fırat, M.; Tosun, İ.; Alitntop, Y.A.; et al. Detection of class 1 integron in Acinetobacter baumannii isolates collected from nine hospitals in Turkey. Asian Pac. J. Trop. Biomed. 2013, 3, 743-747. [CrossRef]

179. Iraz, M.; Duzgun, A.O.; Cicek, A.C.; Bonnin, R.A.; Ceylan, A.; Saral, A.; Nordmann, P.; Sandalli, C. Characterization of novel VIM carbapenemase, VIM-38, and first detection of GES-5 carbapenem-hydrolyzing $\beta$-lactamases in Pseudomonas aeruginosa in Turkey. Diagn. Microbiol. Infect. Dis. 2014, 78, 292-294. [CrossRef]

180. Ku, W.W.; Kung, C.H.; Lee, C.H.; Tseng, C.P.; Wu, P.F.; Kuo, S.C.; Chen, T.L.; Lee, Y.T.; Wang, F.D.; Fung, C.P. Evolution of carbapenem resistance in Acinetobacter baumannii: An 18-year longitudinal study from a medical center in northern Taiwan. J. Microbiol. Immunol. Infect. 2015, 48, 57-64. [CrossRef]

181. Temkin, E.; Adler, A.; Lerner, A.; Carmeli, Y. Carbapenem-resistant Enterobacteriaceae: Biology, epidemiology, and management. Ann. N. Y. Acad. Sci. 2015, 1323, 22-42. [CrossRef]

182. Milan, A.; Furlanis, L.; Cian, F.; Bressan, R.; Luzzati, R.; Lagatolla, C.; Deiana, M.L.; Knezevich, A.; Tonin, E.; Dolzani, L. Epidemic dissemination of a carbapenem-resistant Acinetobacter baumannii clone carrying arma two years after its first isolation in an Italian hospital. Microb. Drug Resist. 2016, 22, 668-674. [CrossRef] [PubMed]

183. Swathi, C.H.; Chikala, R.; Ratnakar, K.S.; Sritharan, V. A structural, epidemiological \& genetic overview of Klebsiella pneumoniae carbapenemases (KPCs). Indian J. Med. Res. 2016, 144, 21-31. [PubMed]

184. Piazza, A.; Caltagirone, M.; Bitar, I.; Nucleo, E.; Spalla, M.; Fogato, E.; D’Angelo, R.; Pagani, L.; Migliavacca, R. Emergence of Escherichia coli sequence type 131 (ST131) and ST3948 with KPC-2, KPC-3 and KPC-8 carbapenemases from a long-term care and rehabilitation facility (LTCRF) in Northern Italy. Adv. Exp. Med. Biol. 2016, 901, 77-89. [PubMed]

185. Stansly, P.G.; Shepherd, R.G.; White, J. Polymyxin: A new chemotherapeutic agent. Bull. Johns Hopkins Hosp. 1947, 81, 43-54. [PubMed]

186. Vaara, M.; Porro, M. Group of peptides that act synergistically with hydrophobic antibiotics against gram-negative enteric bacteria. Antimicrob. Agents Chemother. 1996, 40, 1801-1805. [CrossRef]

187. Falagas, M.E.; Rafailidis, P.I. Attributable mortality of Acinetobacter baumannii: No longer a controversial issue. Crit. Care 2007, 11, 134. [CrossRef]

188. Falagas, M.E.; Rafailidis, P.I. Nephrotoxicity of colistin: New insight into an old antibiotic. Clin. Infect. Dis. 2009, 48, 1729-1731. [CrossRef]

189. Kádár, B.; Kocsis, B.; Nagy, K.; Szabó, D. The renaissance of polymyxins. Curr. Med. Chem. 2013, 20, 3759-3773. [CrossRef]

190. Kelesidis, T.; Falagas, M.E. The safety of polymyxin antibiotics. Expert Opin. Drug Safety 2015, 14, $1687-1701$. [CrossRef]

191. Poulikakos, P.; Tansarli, G.S.; Falagas, M.E. Combination antibiotic treatment versus monotherapy for multidrug-resistant, extensively drug-resistant, and pandrug-resistant Acinetobacter infections: A systematic review. Eur. J. Clin. Microbiol. Infect. Dis. 2014, 33, 1675-1685. [CrossRef]

192. Loho, T.; Dharmayanti, A. Colistin: An antibiotic and its role in multiresistant Gram-negative infections. Acta. Med. Indones. 2015, 47, 157-168. [PubMed]

193. Cai, Y.; Cha, D.; Wang, R.; Liang, B.; Bai, N. Colistin resistance of Acinetobacter baumannii: Clinical reports, mechanisms and antimicrobial strategies. J. Antimicrob. Chemother. 2012, 67, 1607-1615. [CrossRef] [PubMed]

194. Cai, Y.; Lee, W.; Kwa, A.L. Polymyxin B versus colistin: An update. Expert Rev. Anti Infect. Ther. 2015, 13, 1481-1497. [CrossRef] [PubMed]

195. Vaara, M.; Vaara, T.; Jensen, M.; Helander, I.; Nurminen, M.; Rietschel, E.T.; Mäkelä, P.H. Characterization of the lipopolysaccharide from the polymyxin-resistant pmrA mutants of Salmonella typhimurium. FEBS Lett. 1981, 129, 145-149. [CrossRef]

196. El-Sayed Ahmed, M.A.E.; Zhong, L.L.; Shen, C.; Yang, Y.; Doi, Y.; Tian, G.B. Colistin and its role in the Era of antibiotic resistance: an extended review (2000-2019). Emerg Microbes Infect. 2020, 9, 868-885. [CrossRef] [PubMed]

197. Sun, J.; Zeng, X.; Li, X.P.; Liao, X.P.; Liu, Y.H.; Lin, J. Plasmid-mediated colistin resistance in animals: Current status and future directions. Anim. Health Res. Rev. 2017, 18, 136-152. [CrossRef] [PubMed]

198. Sun, J.; Zhang, H.; Liu, Y.H.; Feng, Y. Towards understanding MCR-like colistin resistance. Trends Microbiol. 2018, 26, 794-808. [CrossRef]

199. Al-Tawfiq, J.A.; Laxminarayan, R.; Mendelson, M. How should we respond to the emergence of plasmid-mediated colistin resistance in humans and animals? Int. J. Infect. Dis. 2017, 54, 77-84. [CrossRef] 
200. Lima, T.; Domingues, S.; Da Silva, G.J. Plasmid-mediated colistin resistance in Salmonella enterica: A Review. Microorganisms 2019, 7, 55. [CrossRef]

201. Anyanwu, M.U.; Jaja, I.F.; Nwobi, O.C. Occurrence and characteristics of mobile colistin resistance ( $m c r)$ gene-containing isolates from the environment: A Review. Int. J. Environ. Res. Public Health 2020, 17, E1028. [CrossRef]

202. Karaiskos, I.; Souli, M.; Galani, I.; Giamarellou, H. Colistin: Still a lifesaver for the 21st century? Expert Opin. Drug Metab. Toxicol. 2017, 13, 59-71. [CrossRef] [PubMed]

203. Da Silva, G.J.; Domingues, S. Interplay between colistin resistance, virulence and fitness in Acinetobacter baumannii. Antibiotics 2017, 6, 28. [CrossRef] [PubMed]

204. Olaitan, A.O.; Morand, S.; Rolain, J.M. Mechanisms of polymyxin resistance: Acquired and intrinsic resistance in bacteria. Front. Microbiol. 2014, 5, 643. [CrossRef] [PubMed]

205. Bialvaei, A.Z.; Kafil, S.H. Colistin, mechanisms and prevalence of resistance. Curr. Med. Res. Opin. 2015, 31, 707-721. [CrossRef] [PubMed]

206. Yu, Z.; Qin, W.; Lin, J.; Fang, S.; Qiu, J. Antibacterial mechanisms of polymyxin and bacterial resistance. Biomed Res. Int. 2015, 2015, 679109. [CrossRef] [PubMed]

207. Otter, J.A.; Doumith, M.; Davies, F.; Mookerjee, S.; Dyakova, E.; Gilchrist, M.; Brannigan, E.T.; Bamford, K.; Galletly, T.; Donaldson, H.; et al. Emergence and clonal spread of colistin resistance due to multiple mutational mechanisms in carbapenemase-producing Klebsiella pneumoniae in London. Sci. Rep. 2017, 7, 12711. [CrossRef] [PubMed]

208. López-Causapé, C.; Cabot, G.; Del Barrio-Tofiño, E.; Oliver, A. The versatile mutational resistome of Pseudomonas aeruginosa. Front. Microbiol. 2018, 9, 685. [CrossRef] [PubMed]

209. Mlynarcik, P.; Kolar, M. Molecular mechanisms of polymyxin resistance and detection of mor genes. Biomed. Pap. Med. Fac. Univ. Palacky Olomouc Czech Repub. 2019, 163, 28-38. [CrossRef]

210. Caniaux, I.; van Belkum, A.; Zambardi, G.; Poirel, L.; Gros, M.F. MCR: Modern colistin resistance. Eur. J. Clin. Microbiol. Infect. Dis. 2017, 36, 415-420. [CrossRef]

211. Feng, Y. Transferability of MCR-1/2 polymyxin resistance: Complex dissemination and genetic mechanism. ACS Infect. Dis. 2018, 4, 291-300. [CrossRef]

212. Jochumsen, N.; Marvig, R.L.; Damkiær, S.; Jensen, R.L.; Paulander, W.; Molin, S.; Jelsbak, L.; Folkesson, A. The evolution of antimicrobial peptide resistance in Pseudomonas aeruginosa is shaped by strong epistatic interactions. Nature Comm. 2016, 7, 1-10. [CrossRef] [PubMed]

213. Srinivasan, V.B.; Venkataramaiah, M.; Mondal, A.; Rajamohan, G. Functional characterization of AbeD, an RND-type membrane transporter in antimicrobial resistance in Acinetobacter baumannii. PLoS ONE 2015, 10, e0141314. [CrossRef] [PubMed]

214. Potron, A.; Poirel, L.; Nordmann, P. Emerging broad-spectrum resistance in Pseudomonas aeruginosa and Acinetobacter baumannii: Mechanisms and epidemiology. Int. J. Antimicrob. Agents 2015, 45, 568-585. [CrossRef] [PubMed]

215. Potron, A.; Bour, M.; Triponney, P.; Muller, J.; Koebel, C.; Bonnin, R.A.; Plésiat, P. Sequential emergence of colistin and rifampicin resistance in an OXA-72- producing outbreak strain of Acinetobacter baumannii. Int. J. Antimicrob. Agents 2019, 53, 669-673. [CrossRef] [PubMed]

216. Trebosc, V.; Gartenmann, S.; Tötzl, M.; Lucchini, V.; Schellhorn, B.; Pieren, M.; Lociuro, S.; Gitzinger, M.; Tigges, M.; Bumann, D.; et al. Dissecting colistin resistance mechanisms in extensively drug-resistant Acinetobacter baumannii clinical isolates. MBio 2019, 10, e01083-19. [CrossRef] [PubMed]

217. Romano, K.P.; Warrier, T.; Poulsen, B.E.; Nguyen, P.H.; Loftis, A.R.; Saebi, A.; Pentelute, B.L.; Hung, D.T. Mutations in pmrB confer cross-resistance between the LptD inhibitor POL7080 and colistin in Pseudomonas aeruginosa. Antimicrob. Agents Chemother. 2019, 63, e00511-19. [CrossRef]

218. Chew, K.L.; La, M.V.; Lin, R.T.P.; Teo, J.W.P. Colistin and polymyxin B susceptibility testing for carbapenem-resistant and mcr-positive Enterobacteriaceae: Comparison of sensititre, microscan, vitek 2, and etest with broth microdilution. J. Clin. Microbiol. 2017, 55, 2609-2616. [CrossRef]

219. Shankar, C.; Venkatesan, M.; Rajan, R.; Mani, D.; Lal, B.; Prakash, J.A.J.; Anandan, S.; Pragasam, A.K.; Walia, K.; Ohri, V.C.; et al. Molecular characterization of colistin-resistant Klebsiella pneumoniae \& its clonal relationship among Indian isolates. Indian J. Med. Res. 2019, 149, 199-207.

220. Huang, L.; Feng, Y.; Zong, Z. Heterogeneous resistance to colistin in Enterobacter cloacae complex due to a new small transmembrane protein. J. Antimicrob. Chemother. 2019, 74, 2551-2558. [CrossRef] 
221. Yi, L.X.; Liu, Y.Y.; Wu, R.; Liang, Z.S.; Liu, J.H. Research progress on the plasmid-mediated colistin resistance gene mcr-1. Yi Chuan 2017, 39, 110-126.

222. Feng, S.; Shen, C.; Chen, H.; Zheng, X.; Xia, Y.; Zhong, L.L.; Huang, X.; Wu, X.; Tian, G.B. Co-production of MCR-1 and NDM-5 in Escherichia coli isolated from a colonization case of inpatient. Infect. Drug Resist. 2018, 11, 1157-1161. [CrossRef] [PubMed]

223. Idowu, T.; Arthur, G.; Zhanel, G.G.; Schweizer, F. Heterodimeric Rifampicin-Tobramycin conjugates break intrinsic resistance of Pseudomonas aeruginosa to doxycycline and chloramphenicol in vitro and in a Galleria mellonella in vivo model. Eur. J. Med. Chem. 2019, 174, 16-32. [CrossRef] [PubMed]

224. Idowu, T.; Ammeter, D.; Arthur, G.; Zhanel, G.G.; Schweizer, F. Potentiation of $\beta$-lactam antibiotics and $\beta$-lactam/ $\beta$-lactamase inhibitor combinations against MDR and XDR Pseudomonas aeruginosa using non-ribosomal tobramycin-cyclam conjugates. J. Antimicrob. Chemother. 2019, 74, 2640-2648. [CrossRef]

225. Perez, F.; El Chakhtoura, N.G.; Yasmin, M.; Bonomo, R.A. Polymyxins: To combine or not to combine? Antibiotics 2019, 8, 38. [CrossRef]

226. Kim, T.H.; Tao, X.; Moya, B.; Jiao, Y.; Basso, K.B.; Zhou, J.; Lang, Y.; Sutaria, D.S.; Zavascki, A.P.; Barth, A.L.; et al. Novel Cassette Assay To Quantify the Outer Membrane Permeability of Five $\beta$-Lactams Simultaneously in Carbapenem-Resistant Klebsiella pneumoniae and Enterobacter cloacae. mBio 2020, 11, e03189-19. [CrossRef] [PubMed]

227. Toala, P.; McDonald, A.; Wilcox, C.; Finland, M. Susceptibility of group D Streptococcus (Enterococcus) to 21 antibiotics in vitro, with special reference to species differences. Am. J. Med. Sci. 1969, 258, 416-430. [CrossRef]

228. Seligman, S.J. Penicillinase-negative variants of methicillin-resistant Staphylococcus aureus. Nature 1966, 209, 994-996. [CrossRef] [PubMed]

229. Williamson, R.; Calderwood, S.B.; Moellering, R.C., Jr.; Tomasz, A. Studies on the mechanism of intrinsic resistance to $\beta$-lactam antibiotics in group D Streptococci. J. Gen. Microbiol. 1983, 129, 813-822. [CrossRef]

230. Fuda, C.C.; Fisher, J.F.; Mobashery, S. Beta-lactam resistance in Staphylococcus aureus: The adaptive resistance of a plastic genome. Cell Mol. Life Sci. 2005, 62, 2617-2633. [CrossRef]

231. Peck, S.M. Problem of the resistant Staphylococcus in infections of the skin. N. Y. State J. Med. 1961, 61, 4168-4184.

232. Moellering, R.C., Jr. Current treatment options for community-acquired methicillin-resistant Staphylococcus aureus infection. Clin. Infect. Dis. 2008, 46, 1032-1037. [CrossRef]

233. Sakoulas, G.; Moellering, R.C., Jr. Increasing antibiotic resistance among methicillin-resistant Staphylococcus aureus strains. Clin. Infect. Dis. 2008, 46, S360-S367. [CrossRef]

234. Howe, R.A.; Bowker, K.E.; Walsh, T.R.; Feest, T.G.; MacGowan, A.P. Vancomycin-resistant Staphylococcus aureus. Lancet 1998, 351, 602. [CrossRef]

235. Planet, P.J.; Diaz, L.; Kolokotronis, S.O.; Narechania, A.; Reyes, J.; Xing, G.; Rincon, S.; Smith, H.; Panesso, D.; Ryan, C.; et al. Parallel epidemics of community-associated methicillin-resistant Staphylococcus aureus USA300 infection in North and South America. J. Infect. Dis. 2015, 212, 1874-1882. [CrossRef] [PubMed]

236. Turner, N.A.; Sharma-Kuinkel, B.K.; Maskarinec, S.A.; Eichenberger, E.M.; Shah, P.P.; Carugati, M.; Holland, T.L.; Fowler, V.G. Methicillin-resistant Staphylococcus aureus: An overview of basic and clinical research. Nat. Rev. Microbiol. 2019, 17, 203-218. [CrossRef]

237. Madhavan, K.; Chieng, L.O.; Armstrong, V.L.; Wang, M.Y. Spondylodiscitis in end-stage renal disease: A systematic review. J. Neurosurg. Spine 2019, 15, 1-9. [CrossRef]

238. Khan, T.M.; Kok, Y.L.; Bukhsh, A.; Lee, L.H.; Chan, K.G.; Goh, B.H. Incidence of methicillin resistant Staphylococcus aureus (MRSA) in burn intensive care unit: A systematic review. Germs 2018, 8, 113-125. [CrossRef]

239. Kalligeros, M.; Shehadeh, F.; Karageorgos, S.A.; Zacharioudakis, I.M.; Mylonakis, E. MRSA colonization and acquisition in the burn unit: A systematic review and meta-analysis. Burn 2019, 45, 1528-1536. [CrossRef]

240. Galar, A.; Weil, A.A.; Dudzinski, D.M.; Muñoz, P.; Siedner, M.J. methicillin-resistant Staphylococcus aureus prosthetic valve endocarditis: Pathophysiology, epidemiology, clinical presentation, diagnosis, and management. Clin. Microbiol. Rev. 2019, 32, e00041-18. [CrossRef] [PubMed]

241. Wang, T.Z.; Kodiyanplakkal, R.P.L.; Calfee, D.P. Antimicrobial resistance in nephrology. Nat. Rev. Nephrol. 2019, 15, 463-481. [CrossRef] [PubMed]

242. Gajdács, M. The continuing threat of Methicillin-Resistant Staphylococcus aureus. Antibiotics 2019, 8, 52. [CrossRef] [PubMed] 
243. Couto, N.; Monchique, C.; Belas, A.; Marques, C.; Gama, L.T.; Pomba, C. Trends and molecular mechanisms of antimicrobial resistance in clinical staphylococci isolated from companion animals over a 16-year period. J. Antimicrob Chemother. 2016, 71, 1479-1487. [CrossRef] [PubMed]

244. Ruzauskas, M.; Couto, N.; Pavilonis, A.; Klimiene, I.; Siugzdiniene, R.; Virgailis, M.; Vaskeviciute, L.; Anskiene, L.; Pomba, C. Characterization of Staphylococcus pseudointermedius isolated from diseased dogs in Lithuania. Pol. J. Vet. Sci. 2016, 19, 7-14. [CrossRef]

245. Gonzales, P.R.; Pesesky, M.W.; Bouley, R.; Ballard, A.; Biddy, B.A.; Suckow, M.A.; Wolter, W.R.; Schroeder, V.A.; Burnham, C.A.D.; Mobashery, S.; et al. Synergistic, collaterally sensitive $\beta$-lactam combinations suppress resistance in MRSA. Nat. Chem. Biol. 2015, 11, 855-861. [CrossRef]

246. Tenover, F.C.; Sinner, S.W.; Segal, R.E.; Huang, V.; Alexandre, S.S.; McGowan, J.E., Jr.; Weinstein, M.P. Characterization of a Staphylococcus aureus strain with progressive loss of susceptibility to vancomycin and daptomycin during therapy. Int. J. Antimicrob. Agents 2008, 33, 564-568. [CrossRef]

247. Murakami, K.; Tomasz, A. Involvement of multiple genetic determinants in high-level methicillin resistance in Staphylococcus aureus. J. Bacteriol. 1989, 171, 874-879. [CrossRef]

248. Chambers, H.F. Methicillin resistance in staphylococci: Molecular and biochemical basis and clinical implications. Clin. Microbiol. Rev. 1997, 10, 781-791. [CrossRef]

249. Tomasz, A.; Drugeon, H.B.; de Lencastre, H.M.; Jabes, D.; McDougall, L.; Bille, J. New mechanism for methicillin resistance in Staphylococcus aureus: Clinical isolates that lack the PBP 2a gene and contain normal penicillin-binding proteins with modified penicillin-binding capacity. Antimicrob. Agents Chemother. 1989, 33, 1869-1874. [CrossRef]

250. Massidda, O.; Montanari, M.P.; Varaldo, P.E. Evidence for a methicillin-hydrolysing beta-lactamase in Staphylococcus aureus strains with borderline susceptibility to this drug. FEMS Microbiol. Lett. 1992, 71, $223-227$.

251. Tomasz, A. Accelerated evolution: Emergence of multidrug resistant gram-positive bacterial pathogens in the 1990's. Neth. J. Med. 1998, 52, 219-524. [CrossRef]

252. Crisóstomo, M.I.; Westh, H.; Tomasz, A.; Chung, M.; Oliveira, D.C.; de Lencastre, H. The evolution of methicillin resistance in Staphylococcus aureus: Similarity of genetic backgrounds in historically early methicillin-susceptible and -resistant isolates and contemporary epidemic clones. Proc. Natl. Acad. Sci. USA 2001, 98, 9865-9870. [CrossRef]

253. Antignac, A.; Tomasz, A. Reconstruction of the phenotypes of methicillin-resistant Staphylococcus aureus by replacement of the staphylococcal cassette chromosome mec with a plasmid-borne copy of Staphylococcus sciuri pbpD gene. Antimicrob. Agents Chemother. 2009, 53, 435-441. [CrossRef] [PubMed]

254. Ito, T.; Hiramatsu, K.; Tomasz, A.; de Lencastre, H.; Perreten, V.; Holden, M.T.; Coleman, D.C.; Goering, R.; Giffard, P.M.; Skov, R.L.; et al. International Working Group on the Classification of Staphylococcal Cassette Chromosome elements (IWGSCC). Guidelines for reporting novel mecA gene homologues. Antimicrob. Agents Chemother. 2012, 56, 4997-4999. [CrossRef] [PubMed]

255. Rolo, J.; Worning, P.; Nielsen, J.B.; Bowden, R.; Bouchami, O.; Damborg, P.; Guardabassi, L.; Perreten, V.; Tomasz, A.; Westh, H.; et al. Evolutionary origin of the Staphylococcal Cassette Chromosome mec (SCCmec). Antimicrob. Agents Chemother. 2017, 61, e02302-16. [CrossRef]

256. Tickler, I.A.; Goering, R.V.; Mediavilla, J.R.; Kreiswirth, B.N.; Tenover, F.C. HAI Consortium. Continued expansion of USA300-like methicillin-resistant Staphylococcus aureus (MRSA) among hospitalized patients in the United States. Diagn. Microbiol. Infect. Dis. 2017, 88, 342-347. [CrossRef]

257. Harkins, C.P.; Pichon, B.; Doumith, M.; Parkhill, J.; Westh, H.; Tomasz, A.; de Lencastre, H.; Bentley, S.D.; Kearns, A.M.; Holden, M.T. Methicillin-resistant Staphylococcus aureus emerged long before the introduction of methicillin into clinical practice. Genome Biol. 2017, 18, 30. [CrossRef]

258. Sobral, R.; Tomasz, A. The staphylococcal cell wall. Microbiol. Spectr 2019, 7. [CrossRef] [PubMed]

259. Vollmer, W.; Massidda, O.; Tomasz, A. The cell wall of Streptococcus pneumonia. Microbiol. Spectr. $2019,7$. [CrossRef]

260. Gilmore, M. The Enterococci: Pathogenesis, Molecular Biology and Antimicrobial Resistance; ASM Press: Washington, DC, USA, 2002.

261. Gordon, K.A.; Beach, M.L.; Biedenbach, D.J.; Jones, R.N.; Rhomberg, P.R.; Mutnick, A.H. Antimicrobial susceptibility patterns of beta-hemolytic and viridans group streptococci: Report from the SENTRY Antimicrobial Surveillance Program (1997-2000). Diagn Microbiol. Infect. Dis. 2002, 43, 157-162. [CrossRef] 
262. Robbins, W.C.; Tompsett, R. Treatment of enterococcal endocarditis and bacteremia; results of combined therapy with penicillin and streptomycin. Am. J. Med. 1951, 10, 278-299. [CrossRef]

263. Waksman, S.A. Antibiotic substances-contribution of the microbiologist. N. Y. Acad. Sci. 2010, 1213, $107-111$. [CrossRef]

264. Baddour, L.M.; Wilson, W.R.; Bayer, A.S.; Fowler, V.G., Jr.; Bolger, A.F.; Levison, M.E.; Ferrieri, P.; Gerber, M.A.; Tani, L.Y.; Gewitz, M.H.; et al. Infective endocarditis: Diagnosis, antimicrobial therapy, and management of complications: A statement for healthcare professionals from the Committee on Rheumatic Fever, Endocarditis, and Kawasaki Disease, Council on Cardiovascular Disease in the Young, and the Councils on Clinical Cardiology, Stroke, and Cardiovascular Surgery and Anesthesia, American Heart Association: Endorsed by the Infectious Diseases Society of America. Circulation 2005, 111, e394. [CrossRef]

265. Gilmore, M.S.; Lebreton, F.; van Schaik, W. Genomic transition of Enterococci from gut commensals to leading causes of multidrug-resistant hospital infection in the antibiotic era. Curr. Opin. Microbiol. 2013, 16, 10-16. [CrossRef]

266. Lebreton, F.; van Schaik, W.; McGuire, A.M.; Godfrey, P.; Griggs, A.; Mazumdar, V.; Corander, J.; Cheng, L.; Saif, S.; Young, S.; et al. Emergence of epidemic multidrug-resistant Enterococcus faecium from animal and commensal strains. MBio 2013, 4, e00534-13. [CrossRef]

267. Lebreton, F.; Willems, R.J.L.; Gilmore, M.S. Enterococcus diversity, origins in nature, and gut colonization. In Enterococci: From Commensals to Leading Causes of Drug Resistant Infection; Gilmore, M.S., Clewell, D.B., Ike, Y., Shankar, N., Eds.; Massachusetts Eye and Ear Infirmary: Boston, MA, USA, 2014.

268. Lebreton, F.; Valentino, M.D.; Schaufler, K.; Earl, A.M.; Cattoir, V.; Gilmore, M.S. Transferable vancomycin resistance in clade B commensal-type Enterococcus faecium. J Antimicrob Chemother. 2018, 73, 1479-1486. [CrossRef]

269. Pfaller, M.A.; Cormican, M.; Flamm, R.K.; Mendes, R.E.; Jones, R.N. Temporal and geographic variation in antimicrobial susceptibility and resistance patterns of enterococci: Results from the SENTRY Antimicrobial Surveillance Program, 1997-2016. Open Forum Infect. Dis. 2019, 6, S54-S62. [CrossRef]

270. Hidron, A.I.; Edwards, J.R.; Patel, J.; Horan, T.C.; Sievert, D.M.; Pollock, D.A.; Fridkin, S.K. Antimicrobialresistant pathogens associated with healthcare-associated infections: Annual summary of data reported to the National Healthcare Safety Network at the Centers for Disease Control and Prevention, 2006-2007. Infect. Control Hosp. Epidemiol. 2008, 29, 996-1011. [CrossRef]

271. Ahmed, M.O.; Baptiste, K.E. Vancomycin-Resistant Enterococci: A Review of antimicrobial resistance mechanisms and perspectives of human and animal health. Microb. Drug Resist. 2018, 24, 590-606. [CrossRef] [PubMed]

272. Coupri, D.; Budin-Verneuil, A.; Hartke, A.; Benachour, A.; Léger, L.; Lequeux, T.; Pfund, E.; Verneuil, N. Genetic and pharmacological inactivation of d-alanylation of teichoic acids sensitizes pathogenic enterococci to $\beta$-lactams. J. Antimicrob. Chemother. 2019, 74, 3162-3169. [CrossRef]

273. Tran, T.T.; Munita, J.M.; Arias, C.A. Mechanisms of drug resistance: Daptomycin resistance. Ann. N. Y. Acad. Sci. 2015, 1354, 32-53. [CrossRef]

274. Hollenbeck, B.L.; Rice, L.B. Intrinsic and acquired resistance mechanisms in enterococcus. Virulence 2012, 3, 421-433. [CrossRef] [PubMed]

275. Hassan, M.; Brede, D.A.; Diep, D.B.; Nes, I.F.; Lotfipour, F.; Hojabri, Z. Efficient inactivation of multi-antibiotics resistant nosocomial Enterococci by purified hiracin Bacteriocin. Adv. Pharm. Bull. 2015, 5, 393-401. [CrossRef] [PubMed]

276. Faron, M.L.; Ledeboer, N.A.; Buchan, B.W. Resistance mechanisms, epidemiology, and approaches to screening for vancomycin-resistant Enterococcus in the health care setting. J. Clin. Microbiol. 2016, 54, 2436-2447. [CrossRef] [PubMed]

277. Sauvageot, N.; Mokhtari, A.; Joyet, P.; Budin-Verneuil, A.; Blancato, V.S.; Repizo, G.D.; Henry, C.; Pikis, A.; Thompson, J.; Magni, C.; et al. Enterococcus faecalis uses a phosphotransferase system permease and a host colonization-related ABC transporter for maltodextrin uptake. J. Bacteriol. 2017, 199, e00878-16. [CrossRef]

278. Macesic, N.; Nelson, B.; Mcconville, T.H.; Giddins, M.J.; Green, D.A.; Stump, S.; Gomez-Simmonds, A.; Annavajhala, M.K.; Uhlemann, A.C. Emergence of Polymyxin Resistance in Clinical Klebsiella pneumoniae Through Diverse Genetic Adaptations: A Genomic, Retrospective Cohort Study. Clin. Infect Dis. 2020, 70, 2084-2091. [CrossRef] [PubMed]

279. Murray, B.E. Beta-lactamase-producing Enterococci. Antimicrob. Agents Chemother. 1992, 36, 2355-2359. [CrossRef] 
280. Turolla, A.; Sabatino, R.; Fontaneto, D.; Eckert, E.M.; Colinas, N.; Corno, G.; Citterio, B.; Biavasco, F.; Antonelli, M.; Mauro, A.; et al. Defence strategies and antibiotic resistance gene abundance in enterococci under stress by exposure to low doses of peracetic acid. Chemosphere 2017, 185, 480-488. [CrossRef]

281. Bedenić, B.; Sardelić, S.; Ladavac, M. Multiresistant bacteria. Acta Med. Croatica 2015, 69, 211-216.

282. Morosini, M.I.; Díez-Aguilar, M.; Cantón, R. Mechanisms of action and antimicrobial activity of ceftobiprole. Rev. Esp. Quimioter 2019, 32, 3-10.

283. Rajagopal, M.; Walker, S. Envelope structures of gram-positive bacteria. Curr. Top. Microbiol. Immunol. 2017, 404, 1-44.

284. Kilian, R.; Frasch, H.J.; Kulik, A.; Wohlleben, W.; Stegmann, E. The VanRS homologous two-component system VnlRSAb of the glycopeptide producer Amycolatopsis balhimycina activates transcription of the vanHAXSc genes in Streptomyces coelicolor, but not in A. balhimycina. Microb. Drug Resist. 2016, 22, 499-509. [CrossRef] [PubMed]

285. Chang,J.D.; Foster, E.E.; Wallace, A.G.; Kim, S.J. Peptidoglycan O-acetylation increases in response to vancomycin treatment in vancomycin-resistant Enterococcus faecalis. Sci. Rep. 2017, 7, 46500. [CrossRef] [PubMed]

286. Chang, J.D.; Foster, E.E.; Yang, H.; Kim, S.J. Quantification of the d-Ala-d-Lac-terminated peptidoglycan structure in vancomycin-resistant Enterococcus faecalis using a combined solid-state nuclear magnetic resonance and mass spectrometry analysis. Biochemistry 2017, 56, 612-622. [CrossRef]

287. Chang, J.D.; Foster, E.E.; Thadani, A.N.; Ramirez, A.J.; Kim, S.J. Inhibition of Staphylococcus aureus cell wall biosynthesis by desleucyl-oritavancin: A quantitative peptidoglycan composition analysis by mass spectrometry. J. Bacteriol. 2017, 199, e00278-17. [CrossRef]

288. Ladjouzi, R.; Bizzini, A.; Lebreton, F.; Sauvageot, N.; Rincé, A.; Benachour, A.; Hartke, A. Analysis of the tolerance of pathogenic enterococci and Staphylococcus aureus to cell wall active antibiotics. J. Antimicrob. Chemother. 2013, 68, 2083-2091. [CrossRef]

289. Master, R.N.; Deane, J.; Opiela, C.; Sahm, D.F. Recent trends in resistance to cell envelope-active antibacterial agents among key bacterial pathogens. Ann. N. Y. Acad. Sci. 2013, 1277, 1-7. [CrossRef]

290. Dulberger, C.L.; Rubin, E.J.; Boutte, C.C. The mycobacterial cell envelope - a moving target. Nat. Rev. Microbiol. 2020, 18, 47-59. [CrossRef]

291. Hung, W.W.; Chen, Y.H.; Tseng, S.P.; Jao, Y.T.; Teng, L.J.; Hung, W.C. Using groEL as the target for identification of Enterococcus faecium clades and 7 clinically relevant Enterococcus species. J. Microbiol. Immunol. Infect. 2019, 52, 255-264. [CrossRef]

292. Paganelli, F.L.; de Been, M.; Braat, J.C.; Hoogenboezem, T.; Vink, C.; Bayjanov, J.; Rogers, M.R.C.; Huebner, J.; Bonten, M.J.M.; Willems, R.J.L.; et al. Distinct SagA from hospital-associated clade A1 Enterococcus faecium strains contributes to biofilm formation. Appl. Environ. Microbiol. 2015, 81, 6873-6882. [CrossRef]

293. Montealegre, M.C.; Roh, J.H.; Rae, M.; Davlieva, M.G.; Singh, K.V.; Shamoo, Y.; Murray, B.E. Differential penicillin-binding protein 5 (PBP5) Levels in the Enterococcus faecium clades with different levels of ampicillin resistance. Antimicrob. Agents Chemother. 2016, 61, e02034-16. [CrossRef]

294. Freitas, A.R.; Tedim, A.P.; Novais, C.; Coque, T.M.; Peixe, L. Distribution of putative virulence markers in Enterococcus faecium: Towards a safety profile review. J. Antimicrob. Chemother. 2018, 73, 306-319. [CrossRef] [PubMed]

295. Huo, W.; Adams, H.M.; Trejo, C.; Badia, R.; Palmer, K.L. A Type I restriction-modification system associated with Enterococcus faecium subspecies separation. Appl. Environ. Microbiol. 2019, 85, e02174-18. [CrossRef]

296. Palmer, K.L.; Godfrey, P.; Griggs, A.; Kos, V.N.; Zucker, J.; Desjardins, C.; Cerqueira, G.; Gevers, D.; Walker, S.; Wortman, J.; et al. Comparative genomics of enterococci: Variation in Enterococcus faecalis, clade structure in $E$. faecium, and defining characteristics of E. gallinarum and E. casseliflavus. MBio 2012, 3, e00318-11. [CrossRef]

297. Qin, X.; Galloway-Peña, J.R.; Sillanpaa, J.; Roh, J.H.; Nallapareddy, S.R.; Chowdhury, S.; Bourgogne, A.; Choudhury, T.; Muzny, D.M.; Buhay, C.J.; et al. Complete genome sequence of Enterococcus faecium strain TX16 and comparative genomic analysis of Enterococcus faecium genomes. BMC Microbiol. 2012, 12, 135. [CrossRef] [PubMed]

298. Uttley, A.H.; Woodford, N.; Johnson, A.P.; Cookson, B.; George, R.C. Vancomycin-resistant Enterococci. Lancet 1993, 342, 615. [CrossRef]

299. Top, J.; Willems, R.; Bonten, M. Emergence of CC17 Enterococcus faecium: From commensal to hospital-adapted pathogen. FEMS Immunol. Med. Microbiol. 2008, 52, 297-308. [CrossRef] 
300. Kim, E.B.; Marco, M.L. Nonclinical and clinical Enterococcus faecium strains, but not Enterococcus faecalis strains, have distinct structural and functional genomic features. Appl. Environ. Microbiol. 2014, 80, 154-165. [CrossRef]

301. Douglas, A.P.; Marshall, C.; Baines, S.L.; Ritchie, D.; Szer, J.; Madigan, V.; Chan, H.T.; Ballard, S.A.; Howden, B.P.; Buising, K.; et al. Utilizing genomic analyses to investigate the first outbreak of vanA vancomycin-resistant Enterococcus in Australia with emergence of daptomycin non-susceptibility. J. Med. Microbiol. 2019, 68, 303-308. [CrossRef]

302. Zhang, X.; Paganelli, F.L.; Bierschenk, D.; Kuipers, A.; Bonten, M.J.; Willems, R.J.; Van Schaik, W. Genome-wide identification of ampicillin resistance determinants in Enterococcus faecium. PLoS Genet. 2012, 8, e1002804. [CrossRef]

303. Gilmore, M.S.; Rauch, M.; Ramsey, M.M.; Himes, P.R.; Varahan, S.; Manson, J.M.; Lebreton, F.; Hancock, L.E. Pheromone killing of multidrug-resistant Enterococcus faecalis V583 by native commensal strains. Proc. Natl. Acad. Sci. USA 2015, 112, 7273-7278. [CrossRef]

304. Nilsson, O. Vancomycin resistant Enterococci in farm animals' occurrence and importance. Infect. Ecol. Epidemiol. 2012, 2, 16959. [CrossRef] [PubMed]

305. Mutters, N.T.; Mersch-Sundermann, V.; Mutters, R.; Brandt, C.; Schneider-Brachert, W.; Frank, U. Control of the spread of vancomycin-resistant Enterococci in hospitals: Epidemiology and clinical relevance. Dtsch. Arztebl. Int. 2013, 110, 725-731. [PubMed]

306. Levitus, M.; Perera, T.B. Vancomycin-Resistant Enterococci (VRE); StatPearls Publishing: Treasure Island, FL, USA, 2019.

307. Arias, C.A.; Murray, B.E. The rise of the Enterococcus: Beyond vancomycin resistance. Nat. Rev. Microbiol. 2012, 10, 266-278. [CrossRef] [PubMed]

308. Shenoy, E.S.; Paras, M.L.; Noubary, F.; Walensky, R.P.; Hooper, D.C. Natural history of colonization with methicillin-resistant Staphylococcus aureus (MRSA) and vancomycin-resistant Enterococcus (VRE): A systematic review. BMC Infect. Dis. 2014, 14, 177. [CrossRef]

309. Remschmidt, C.; Behnke, M.; Kola, A.; Diaz, L.A.P.; Rohde, A.M.; Gastmeier, P.; Schwab, F. The effect of antibiotic use on prevalence of nosocomial vancomycin-resistant Enterococci an ecologic study. Antimicrob. Resist. Infect. Control. 2017, 6, 95. [CrossRef]

310. Lewis, J.D.; Barros, A.J.; Sifri, C.D. Comparison of risk factors and outcomes of daptomycin-susceptible and -nonsusceptible vancomycin-resistant Enterococcus faecium infections in liver transplant recipients. Transpl. Infect. Dis. 2018, 20, e12856. [CrossRef]

311. Chen, C.H.; Xu, X.G. Genetic characteristics of vancomycin resistance gene cluster in Enterococcus spp. Yi Chuan 2015, 37, 452-457.

312. Bayjanov, J.R.; Baan, J.; Rogers, M.R.C.; Troelstra, A.; Willems, R.J.L.; van Schaik, W. Enterococcus faecium genome dynamics during long-term asymptomatic patient gut colonization. Microbial Genom. 2019, 7, e000277. [CrossRef]

313. Gorrie, C.; Higgs, C.; Carter, G.; Stinear, T.P.; Howden, B. Genomics of vancomycin-resistant Enterococcus faecium. Microb. Genom. 2019, 5, e000283. [CrossRef]

314. Melegh, S.; Nyül, A.; Kovács, K.; Kovács, T.; Ghidán, Á.; Dombrádi, Z.; Szabó, J.; Berta, B.; Lesinszki, V.; Pászti, J.; et al. Dissemination of VanA-Type Enterococcus faecium isolates in Hungary. Microb. Drug Resist. 2018, 24, 1376-1390. [CrossRef]

315. Lebreton, F.; Depardieu, F.; Bourdon, N.; Fines-Guyon, M.; Berger, P.; Camiade, S.; Leclercq, R.; Courvalin, P.; Cattoir, V. D-Ala-d-Ser VanN-type transferable vancomycin resistance in Enterococcus faecium. Antimicrob. Agents Chemother. 2011, 55, 4606-4612. [CrossRef] [PubMed]

316. Nomura, T.; Tanimoto, K.; Shibayama, K.; Arakawa, Y.; Fujimoto, S.; Ike, Y.; Tomita, H. Identification of VanN-type vancomycin resistance in an Enterococcus faecium isolate from chicken meat in Japan. Antimicrob Agents Chemother. 2012, 56, 6389-6392. [CrossRef]

317. Boyd, D.A.; Lévesque, S.; Picard, A.C.; Golding, G.R. Vancomycin-resistant Enterococcus faecium harbouring vanN in Canada: A case and complete sequence of pEfm12493 harbouring the vanN operon. J. Antimicrob. Chemother. 2015, 70, 2163-2165. [CrossRef]

318. Devriese, L.A.; Cauwerts, K.; Hermans, K.; Wood, A.M. Enterococcus cecorum septicaemia as a cause of bone and joint lesions resulting in lameness in broiler chickens. Vlaams Diergeneeskundig Tijdschrift 2002, 71, 219-221. 
319. Wood, A.M.; MacKenzie, G.; McGillveray, N.C.; Brown, L.; Devriese, L.A.; Baele, M. Isolation of Enterococcus cecorum from bone lesions in broiler chickens. Vet. Record. 2002, 150, 27.

320. Chadfield, M.S.; Christensen, J.P.; Christensen, H.; Bisgaard, M. Characterization of Streptococci and Enterococci associated with septicaemia in broiler parents with a high prevalence of endocarditis. Avian Pathol. 2004, 33, 610-617. [CrossRef]

321. Debnam, A.L.; Jackson, C.R.; Avellaneda, G.E.; Barrett, J.B.; Hofacre, C.L. Effect of growth promotant usage on Enterococci species on a poultry farm. Avian Dis. 2005, 49, 361-365. [CrossRef]

322. Thayer, S.G.; Waltman, W.D.; Wages, D.P. Streptococcus and Enterococcus. In Diseases of Poultry, 12th ed.; Saif, Y.M., Glisson, J.R., McDougald, L.R., Nolan, L.K., Swayne, D.E., Eds.; Blackwell Publishing Professional: Ames, IA, USA, 2008; pp. 900-908.

323. Aziz, T.; Barnes, H.J. Is spondylitis an emerging disease in broilers? World Poultry 2007, 23, $44-45$.

324. Aziz, T.; Barnes, H.J. Spondylitis is emerging in broilers. World Poultry 2009, 25, 19.

325. DeHerdt, P.; Defoort, P.; Steelant, J.V.; Swam, H.; Tanghe, L.; Goethem, S.V.; Vanrobaeys, M. Enterococcus cecorum osteomyelitis and arthritis in broiler chickens. Vlaams Diergeneeskundig Tijdschrift 2008, 78, 44-48.

326. Stalker, M.J.; Brash, M.L.; Weisz, A.; Ouckama, R.M.; Slavic, D. Arthritis and osteomyelitis associated with Enterococcus cecorum infection in broiler and broiler breeder chickens in Ontario, Canada. J. Vet. Diag. Invest. 2010, 22, 643-645. [CrossRef] [PubMed]

327. Martin, L.T.; Martin, M.P.; Barnes, H.J. Experimental reproduction of Enterococcus spondylitis in male broiler breeder chickens. Avian Dis. 2011, 55, 273-278. [CrossRef] [PubMed]

328. Boerlin, P.; Nicholson, V.; Brash, M.; Slavic, D.; Boyen, F.; Sanei, B.; Butaye, P. Diversity of Enterococcus cecorum from chickens. Vet. Microbiol. 2012, 157, 405-411. [CrossRef] [PubMed]

329. Jung, A.; Chen, L.R.; Suyemoto, M.M.; Barnes, H.J.; Borst, L.B. A review of Enterococcus cecorum infection in poultry. Avian Dis. 2018, 62, 261-271. [CrossRef]

330. Griffith, R.S. Introduction to vancomycin. Rev. Infect. Dis. 1981, 3, S200-S204. [CrossRef]

331. Xu, L.; Huang, H.; Wei, W.; Zhong, Y.; Tang, B.; Yuan, H.; Zhu, L.; Huang, W.; Ge, M.; Yang, S.; et al. Complete genome sequence and comparative genomic analyses of the vancomycin-producing Amycolatopsis orientalis. BMC Genom. 2014, 15, 363. [CrossRef]

332. Chen, X.Y.; Xu, R.X.; Zhou, X.; Liu, Y.; Hu, C.Y.; Xie, X.F. Acute kidney injury associated with concomitant vancomycin and piperacillin/tazobactam administration: A systematic review and meta-analysis. Int. Urol. Nephrol. 2018, 50, 2019-2026. [CrossRef]

333. Grabel, Z.J.; Boden, A.; Segal, D.N.; Boden, S.; Milby, A.H.; Heller, J.G. The impact of prophylactic intraoperative vancomycin powder on microbial profile, antibiotic regimen, length of stay, and reoperation rate in elective spine surgery. Spine J. 2019, 19, 261-266. [CrossRef]

334. Mühlberg, E.; Umstätter, F.; Kleist, C.; Domhan, C.; Mier, W.; Uhl, P. Renaissance of vancomycin: Approaches for breaking antibiotic resistance in multidrug-resistant bacteria. Can. J. Microbiol. 2020, 66, 11-16. [CrossRef]

335. Haenni, M.; Saras, E.; Châtre, P.; Meunier, D.; Martin, S.; Lepage, G.; Ménard, M.F.; Lebreton, P.; Rambaud, T.; Madec, J.Y. vanA in Enterococcus faecium, Enterococcus faecalis, and Enterococcus casseliflavus detected in French cattle. Foodborne Pathog. Dis. 2009, 6, 1107-1111. [CrossRef]

336. Gardete, S.; Tomasz, A. Mechanisms of vancomycin resistance in Staphylococcus aureus. J. Clin. Investig. 2014, 124, 2836-2840. [CrossRef] [PubMed]

337. McGuinness, W.A.; Malachowa, N.; DeLeo, F.R. Vancomycin resistance in Staphylococcus aureus. Yale J. Biol. Med. 2017, 90, 269-281.

338. Manges, A.R.; Steiner, T.S.; Wright, A.J. Fecal microbiota transplantation for the intestinal decolonization of extensively antimicrobial-resistant opportunistic pathogens: A review. Infect. Dis. 2016, 48, 587-592. [CrossRef] [PubMed]

339. Satlin, M.J.; Walsh, T.J. Multidrug-resistant Enterobacteriaceae, Pseudomonas aeruginosa, and vancomycinresistant Enterococcus: Three major threats to hematopoietic stem cell transplant recipients. Transpl. Infect. Dis. 2017, 19, e12762. [CrossRef] [PubMed]

340. Vehreschild, M.J.G.T.; Haverkamp, M.; Biehl, L.M.; Lemmen, S.; Fätkenheuer, G. Vancomycin-resistant enterococci (VRE): A reason to isolate? Infection 2019, 47, 7-11. [CrossRef]

341. Stogios, P.J.; Savchenko, A. Molecular mechanisms of vancomycin resistance. Protein Sci. 2020, $29,654-669$. [CrossRef] 
342. Thally, F.P.; DeBruin, M.F. Development of daptomycin for Gram-positive infections. J. Antimicrob. Chemother. 2000, 46, 523-526. [CrossRef]

343. Newman, D.J.; Cragg, G.M. Natural products as sources of new drugs from 1981 to 2014. J. Nat. Prod. 2016, 79, 629-661. [CrossRef]

344. Contreras, G.A.; Munita, J.M.; Arias, C.A. Novel strategies for the management of vancomycin-resistant enterococcal infections. Curr. Infect. Dis. Rep. 2019, 21, 22. [CrossRef]

345. Micklefield, J. Daptomycin structure and mechanism of action revealed. Chem. Biol. 2004, 11, 887-888. [CrossRef]

346. Eisenstein, B.I.; Oleson, F.B., Jr.; Baltz, R.H. Daptomycin: From the mountain to the clinic, with essential help from Francis Tally, MD. Clin Infect Dis. 2010, 50, S10-S15. [CrossRef] [PubMed]

347. Fowler, V.G., Jr.; Boucher, H.W.; Corey, G.R.; Abrutyn, E.; Karchmer, A.W.; Rupp, M.E.; Levine, D.P.; Chambers, H.F.; Tally, F.P.; Vigliani, G.A.; et al. S. aureus Endocarditis and Bacteremia Study Group. Daptomycin versus standard therapy for bacteremia and endocarditis caused by Staphylococcus aureus. N. Engl. J. Med. 2006, 355, 653-665. [CrossRef] [PubMed]

348. Kirkpatrick, P.; Raja, A.; LaBonte, J.; Lebbos, J. Daptomycin. Nat. Rev. Drug Discov. 2003, 2, 943-944. [PubMed]

349. Arbeit, R.D.; Maki, D.; Tally, F.P.; Campanaro, E.; Eisenstein, B.I. The safety and efficacy of daptomycin for the treatment of complicated skin and skin-structure infections. Clin. Infect. Dis. 2004, 38, 1673-1681. [CrossRef] [PubMed]

350. Tong, S.Y.C.; Lye, D.C.; Yahav, D.; Sud, A.; Robinson, J.O.; Nelson, J.; Archuleta, S.; Roberts, M.A.; Cass, A.; Paterson, D.L.; et al. Effect of Vancomycin or Daptomycin With vs Without an Antistaphylococcal $\beta$-Lactam on Mortality, Bacteremia, Relapse, or Treatment Failure in Patients With MRSA Bacteremia: A Randomized Clinical Trial Australasian Society for Infectious Diseases Clinical Research Network. JAMA 2020, 323, 527-537. [CrossRef] [PubMed]

351. Heidary, M.; Khosravi, A.D.; Khoshnood, S.; Nasiri, M.J.; Soleimani, S.; Goudarzi, M. Daptomycin. J. Antimicrob. Chemother. 2018, 73, 1-11. [CrossRef] [PubMed]

352. Patel, S.; Saw, S. Daptomycin; StatPearls Publishing: Treasure Island, FL, USA, 2019.

353. McHenney, M.A.; Baltz, R.H. Gene transfer and transposition mutagenesis in Streptomyces roseosporus: Mapping of insertions that influence daptomycin or pigment production. Microbiology 1996, 142, 2363-2373. [CrossRef]

354. Mchenney, M.A.; Hosted, T.J.; Dehoff, B.S.; Rosteck, P.R.; Baltz, R.H. Molecular cloning and physical mapping of the daptomycin gene cluster from Streptomyces roseosporus. J Bacteriol. 1998, 180, 143-151. [CrossRef]

355. Taylor, S.D.; Palmer, M. The action mechanism of daptomycin. Bioorg. Med. Chem. 2016, 24, $6253-6268$. [CrossRef]

356. Cantón, R.; Ruiz-Garbajosa, P.; Chaves, R.L.; Johnson, A.P. A potential role for daptomycin in enterococcal infections: What is the evidence? J. Antimicrob. Chemother. 2010, 65, 1126-1136. [CrossRef]

357. Arias, C.A.; Panesso, D.; McGrath, D.M.; Qin, X.; Mojica, M.F.; Miller, C.; Diaz, L.; Tran, T.T.; Rincon, S.; Barbu, E.M.; et al. Genetic basis for in vivo daptomycin resistance in enterococci. N. Engl. J. Med. 2011, 365, 892-900. [CrossRef] [PubMed]

358. Hachmann, A.B.; Sevim, E.; Gaballa, A.; Popham, D.L.; Antelmann, H.; Helmann, J.D. Reduction in membrane phosphatidylglycerol content leads to daptomycin resistance in Bacillus subtilis. Antimicrob. Agents Chemother. 2011, 55, 4326-4337. [CrossRef] [PubMed]

359. Kristich, C.J.; Rice, L.B.; Arias, C.A. Enterococcal infection-Treatment and antibiotic resistance. In Enterococci: From Commensals to Leading Causes of Drug Resistant Infection; Gilmore, M.S., Clewell, D.B., Ike, Y., Shankar, N., Eds.; Massachusetts Eye and Ear Infirmary: Boston, MA, USA, 2014; pp. 87-134.

360. Mercuro, N.J.; Davis, S.L.; Zervos, M.J.; Herc, E.S. Combatting resistant enterococcal infections: A pharmacotherapy review. Expert Opin. Pharmacother. 2018, 19, 979-992. [CrossRef] [PubMed]

361. Tran, T.T.; Panesso, D.; Mishra, N.N.; Mileykovskaya, E.; Guan, Z.; Munita, J.M.; Reyes, J.; Diaz, L.; Weinstock, G.M.; Murray, B.E.; et al. Daptomycin-resistant Enterococcus faecalis diverts the antibiotic molecule from the division septum and remodels cell membrane phospholipids. MBio 2013, 4, e00281-13. [CrossRef]

362. Cattoir, V.; Giard, J.C. Antibiotic resistance in Enterococcus faecium clinical isolates. Expert Rev. Anti Infect. Ther. 2014, 12, 239-248. [CrossRef] [PubMed] 
363. Cho, S.Y.; Kim, H.M.; Chung, D.R.; Kim, S.H.; Huh, H.J.; Kang, C.I.; Peck, K.R.; Lee, N.Y.; Song, J.H. Resistance mechanisms and clinical characteristics of linezolid-resistant Enterococcus faecium isolates: A single-centre study in South Korea. J. Glob. Antimicrob. Resist. 2018, 12, 44-47. [CrossRef]

364. Yim, J.; Smith, J.R.; Rybak, M.J. Role of combination antimicrobial therapy for vancomycin-resistant Enterococcus faecium infections: Review of the current evidence. Pharmacotherapy 2017, 37, 579-592. [CrossRef]

365. Mwangi, M.M.; Wu, S.W.; Zhou, Y.; Sieradzki, K.; de Lencastre, H.; Richardson, P.; Bruce, D.; Rubin, E.; Myers, E.; Siggia, E.D.; et al. Tracking the in vivo evolution of multidrug resistance in Staphylococcus aureus by whole-genome sequencing. Proc. Natl. Acad. Sci. USA 2007, 104, 9451-9456. [CrossRef]

366. Casanova, G.N.; Ruiz, S.M.; Bellido, M.J.L. Mechanisms of resistance to daptomycin in Staphylococcus aureus. Rev. Esp. Quimioter 2017, 30, 391-396.

367. Jiang, J.H.; Dexter, C.; Cameron, D.R.; Monk, I.R.; Baines, S.L.; Abbott, I.J.; Spelman, D.W.; Kostoulias, X.; Nethercott, C.; Howden, B.P.; et al. Evolution of daptomycin resistance in coagulase-negative staphylococci involves mutations of the essential two-component regulator WalKR. Antimicrob. Agents Chemother. 2019, 63, e01926-18. [CrossRef]

368. Taglialegna, A.; Varela, M.C.; Rosato, R.R.; Rosato, A.E. VraSR and virulence trait modulation during daptomycin resistance in methicillin-resistant Staphylococcus aureus infection. mSphere 2019, 4, e00557-18. [CrossRef]

369. Matono, T.; Hayakawa, K.; Hirai, R.; Tanimura, A.; Yamamoto, K.; Fujiya, Y.; Mawatari, M.; Kutsuna, S.; Takeshita, N.; Mezaki, K.; et al. Emergence of a daptomycin-non-susceptible Enterococcus faecium strain that encodes mutations in DNA repair genes after high-dose daptomycin therapy. BMC Res. Notes 2016, 9, 197. [CrossRef]

370. Ling, L.L.; Schneider, T.; Peoples, A.J.; Spoering, A.L.; Engels, I.; Conlon, B.P.; Mueller, A.; Schäberle, T.F.; Hughes, D.E.; Epstein, S.; et al. A new antibiotic kills pathogen without detectable resistance. Nature 2015, 517, 455-459. [CrossRef]

371. Iyer, A.; Madder, A.; Singh, I. Teixobactins: A new class of 21st century antibiotics to combat multidrug-resistant bacterial pathogens. Future Microbiol. 2019, 14, 457-460. [CrossRef]

372. Li, Y.X.; Zhong, Z.; Hou, P.; Zhang, W.P.; Qian, P.Y. Resistance to nonribosomal peptide antibiotics mediated by D-stereospecific peptidases. Nat. Chem. Biol. 2018, 14, 381-387. [CrossRef]

373. Karas, J.A.; Chen, F.; Schneider-Futschik, E.K.; Kang, Z.; Hussein, M.; Swarbrick, J.; Hoyer, D.; Giltrap, A.M.; Payne, R.J.; Li, J.; et al. Synthesis and structure-activity relationships of teixobactin. Ann. N. Y. Acad. Sci. 2020, 1459, 86-105. [CrossRef]

374. Yang, H.; Pishenko, A.V.; Li, X.; Nowick, J.S. Design, synthesis, and study of lactam and ring-expanded analogues of teixobactin. J. Org. Chem. 2020, 85, 1331-1339. [CrossRef]

375. He, Y.; Fan, A.; Han, M.; Zhang, Y.; Tong, Y.; Zheng, G.; Zhu, S. New perspectives on the treatment of mycobacterial infections using antibiotics. Appl. Microbiol. Biotechnol. 2020, 104, 4197-4209. [CrossRef]

376. Ötvös, L., Jr.; Wade, J.D. Current challenges in peptide-based drug discovery. Front. Chem. $2014,2,62$. [CrossRef]

377. Lázár, V.; Martins, A.; Spohn, R.; Daruka, L.; Grézal, G.; Pál, C. Antibiotic-resistant bacteria show widespread collateral sensitivity to antimicrobial peptides. Nat. Microbiol. 2018, 3, 718-731. [CrossRef]

378. Ötvös, L., Jr. Antibacterial peptides isolated from insects. J. Pept. Sci. 2000, 6, 497-511.

379. Ötvös, L., Jr.; Wade, J.D.; Lin, F.; Condie, B.A.; Hanrieder, J.; Hoffmann, R. Designer antibacterial peptides kill fluoroquinolone-resistant clinical isolates. J. Med. Chem. 2005, 48, 5349-5359. [CrossRef] [PubMed]

380. Jenssen, H.; Hamill, P.; Hancock, R.E. Peptide antimicrobial agents. Clin. Microbiol. Rev. 2006, 19, 491-511. [CrossRef]

381. Jenssen, H.; Fjell, C.D.; Cherkasov, A.; Hancock, R.E. QSAR modeling and computer-aided design of antimicrobial peptides. J. Pept. Sci. 2008, 14, 110-114. [CrossRef]

382. Schoppet, M.; Tailhades, J.; Kulkarni, K.; Cryle, M.J. Precursor manipulation in glycopeptide antibiotic biosynthesis: Are $\beta$-amino acids compatible with the oxidative cyclization cascade? J. Org. Chem. 2018, 83, 7206-7214. [CrossRef]

383. Spänig, S.; Heider, D. Encodings and models for antimicrobial peptide classification for multi-resistant pathogens. BioData Min 2019, 4, 7. [CrossRef] [PubMed]

384. Schmidt, R.; Knappe, D.; Wend, E.; Ostorházi, E.; Hoffmann, R. In vivo Efficacy and Pharmacokinetics of Optimized Apidaecin Analogs. Front. Chem. 2017, 5, 15. [CrossRef] 
385. Hicks, R.P.; Abercrombie, J.J.; Wong, R.K.; Leung, K.P. Antimicrobial peptides containing unnatural amino acid exhibit potent bactericidal activity against ESKAPE pathogens. Bioorg. Med. Chem. 2012, 21, 205-214. [CrossRef]

386. Ötvös, L., Jr. The short proline-rich antibacterial peptide family. Cell Mol. Life Sci. 2002, 59, 1138-1150. [CrossRef]

387. Taniguchi, M.; Ochiai, A.; Kondo, H.; Fukuda, S.; Ishiyama, Y.; Saitoh, E.; Kato, T.; Tanaka, T. Pyrrhocoricin, a proline-rich antimicrobial peptide derived from insect, inhibits the translation process in the cell-free Escherichia coli protein synthesis system. J. Biosci. Bioeng. 2016, 121, 591-598. [CrossRef]

388. Berrthold, N.; Hoffmann, R. Cellular uptake of apidaecin $1 \mathrm{~b}$ and related analogs in Gram-negative bacteria reveals novel antibacterial mechanism for proline-rich antimicrobial peptides. Protein Pept. Lett. 2014, 21, 391-398. [CrossRef]

389. Wu, S.; Wang, J.; Zhu, L.; Ren, H.; Yang, X. A novel apidaecin Api-PR19 synergizes with the gut microbial community to maintain intestinal health and promote growth performance of broilers. J. Anim. Sci. Biotechnol.. [CrossRef] [PubMed]

390. Knappe, D.; Ruden, S.; Langanke, S.; Tikkoo, T.; Ritzer, J.; Mikut, R.; Martin, L.L.; Hoffmann, R.; Hilpert, K. Optimization of oncocin for antibacterial activity using a SPOT synthesis approach: Extending the pathogen spectrum to Staphylococcus aureus. Amino Acids. 2016, 48, 269-280. [CrossRef]

391. Ötvös, L., Jr.; Ostorházi, E.; Szabó, D.; Zumbrun, S.D.; Miller, L.L.; Halasohoris, S.A.; Desai, P.D.; Int Veldt, S.M.; Kraus, C.N. Synergy Between Proline-Rich Antimicrobial Peptides and Small Molecule Antibiotics Against Selected Gram-Negative Pathogens in vitro and in vivo. Front Chem. 2108, 6, 309. [CrossRef] [PubMed]

392. Ostorházi, E.; Hoffmann, R.; Herth, N.; Wade, J.D.; Kraus, C.N.; Ötvös, L., Jr. Advantage of a Narrow Spectrum Host Defense (Antimicrobial) Peptide Over a Broad Spectrum Analog in Preclinical Drug Development. Front Chem. 2018, 6, 359. [CrossRef] [PubMed]

393. Karlowsky, J.A.; Steenbergen, J.; Zhanel, G.G. Microbiology and preclinical review of omadacycline. Clin. Infect. Dis. 2019, 69, S6-S15. [CrossRef]

394. Zhanel, G.G.; Esquivel, J.; Zelenitsky, S.; Lawrence, C.K.; Adam, H.J.; Golden, A.; Hink, R.; Berry, L.; Schweizer, F.; Zhanel, M.A.; et al. Omadacycline: A novel oral and intravenous aminomethylcycline antibiotic agent. Drugs 2020, 80, 285-313. [CrossRef]

395. Lengyel, K.; Lang, E.; Fodor, A.; Szállás, E.; Schumann, P.; Stackebrandt, E. Description of four novel species of Xenorhabdus, family Enterobacteriaceae: Xenorhabdus budapestensis sp. nov., Xenorhabdus ehlersii sp. nov., Xenorhabdus innexi sp. nov., and Xenorhabdus szentirmaii sp. nov. Syst. Appl. Microbiol. 2005, 28, 115-122. [CrossRef]

396. Furgani, G.; Böszörményi, E.; Fodor, A.; Máthé Fodor, A.; Forst, S.; Hogan, J.S.; Katona, Z.; Klein, M.G.; Stackebrandt, E.; Szentirmai, A.; et al. Xenorhabdus antibiotics: A comparative analysis and potential utility for controlling mastitis caused by bacteria. J. Appl. Microbiol. 2008, 104, 745-758. [CrossRef]

397. Böszörményi, E.; Érsek, T.; Fodor, A.; Fodor, A.M.; Földes, L.S.; Hevesi, M.; Hogan, J.S.; Katona, Z.; Klein, M.G.; Kormány, A.; et al. Isolation and activity of Xenorhabdus antimicrobial compounds against the plant pathogens Erwinia amylovora and Phytophthora nicotianae. J. Appl. Microbiol. 2009, 107, 746-759. [CrossRef]

398. Gualtieri, M.; Ogier, J.C.; Pagès, S.; Givaudan, A.; Gaudriault, S. Draft genome sequence and annotation of the entomopathogenic \bacterium Xenorhabdus szentirmaii Strain DSM16338. Genome Announ. 2014, 2, e00190-14. [CrossRef]

399. Vozik, D.; Bélafi-Bakó, K.; Hevesi, M.; Böszörményi, E.; Fodor, A. Effectiveness of a peptide-rich fraction from xenorhabdus budapestensis culture against fire blight disease on apple blossoms. Notulae Botanicae Horti Agrobotanici Cluj-Napoca 2015, 43, 547-553. [CrossRef]

400. Fuchs, S.W.; Sachs, C.C.; Kegler, C.; Nollmann, F.I.; Karas, M.; Bode, H.B. Neutral loss fragmentation pattern, based screening for arginine-rich natural products in Xenorhabdus and Photorhabdus. Anal. Chem. 2012, 84, 6948-6955. [CrossRef]

401. Fuchs, S.W.; Grundmann, F.; Kurz, M.; Kaiser, M.; Bode, H.B. Fabclavines: Bioactive peptide-polyketidepolyamino hybrids from Xenorhabdus. Chem. BioChem. 2014, 15, 512-516. [CrossRef] [PubMed]

402. Wenski, S.L.; Kolbert, D.; Grammbitter, G.L.C.; Bode, H.B. Fabclavine biosynthesis in X. szentirmaii: Shortened derivatives and characterization of the thioester reductase FclG and the condensation domain-like protein FclL. J. Ind. Microbiol. Biotechnol. 2019, 46, 565-572. [CrossRef] [PubMed] 
403. Donmez Ozkan, H.; Cimen, H.; Ulug, D.; Wenski, S.; Yigit Ozer, S.; Telli, M.; Aydin, N.; Bode, H.B.; Hazir, S. Nematode-associated bacteria: Production of antimicrobial agent as a presumptive nominee for curing endodontic infections caused by Enterococcus faecalis. Front. Microbiol. 2019, 10, 2672. [CrossRef] [PubMed]

404. Kajla, M.K.; Barrett-Wilt, G.A.; Paskewitz, S.M. Bacteria: A novel source for potent mosquito feeding-deterrents. Sci. Adv. 2019, 5, eaau6141. [CrossRef]

405. Ciezki, K.; Wesener, S.; Jaber, D.; Mirza, S.; Forst, S. ngrA-dependent natural products are required for interspecies competition and virulence in the insect pathogenic bacterium Xenorhabdus szentirmaii. Microbiology 2019, 165, 538-553. [CrossRef]

406. Gajdács, M. The concept of an ideal antibiotic: Implications for drug design. Molecules 2019, 24, 892. [CrossRef]

407. Pál, C.; Papp, B.; Lercher, M.J. Adaptive evolution of bacterial metabolic networks by horizontal gene transfer. Nat. Genet. 2005, 37, 1372-1375. [CrossRef]

408. Waclaw, B. Evolution of drug resistance in bacteria. Adv. Exp. Med. Biol. 2016, 915, 49-67.

409. Liu, J.; Gefen, O.; Ronin, I.; Bar-Meir, M.; Balaban, N.Q. Effect of tolerance on the evolution of antibiotic resistance under drug combinations. Science 2020, 10, 200-204. [CrossRef] [PubMed]

410. Brauner, A.; Fridman, O.; Gefen, O.; Balaban, N.Q. Distinguishing between resistance, tolerance and persistence to antibiotic treatment. Nat. Rev. Microbiol. 2016, 14, 320-330. [CrossRef]

411. Balaban, N.Q.; Helaine, S.; Lewis, K.; Ackermann, M.; Aldridge, B.; Andersson, D.I.; Brynildsen, M.P.; Bumann, D.; Camilli, A.; Collins, J.J.; et al. Definitions and guidelines for research on antibiotic persistence. Nat. Rev. Microbiol. 2019, 17, 441-448. [CrossRef]

412. Fridman, O.; Goldberg, A.; Ronin, I.; Shoresh, N.; Balaban, N.Q. Optimization of lag time underlies antibiotic tolerance in evolved bacterial populations. Nature 2014, 513, 418-421. [CrossRef]

413. Kim, J.S.; Wood, T.K. Persistent persister misperceptions. Front. Microbiol. 2016, 7, 2134. [CrossRef]

414. Girgis, H.S.; Harris, K.; Tavazoie, S. Large mutational target size for rapid emergence of bacterial persistence. Proc. Natl Acad. Sci. USA 2012, 109, 12740-12745. [CrossRef]

415. Moyed, H.S.; Bertrand, K.P. hipA, a newly recognized gene of Escherichia coli K-12 that affects frequency of persistence after inhibition of murein synthesis. J. Bacteriol. 1983, 155, 768-775. [CrossRef]

416. Slattery, A.; Victorsen, A.H.; Brown, A.; Hillman, K.; Phillips, G.J. Isolation of highly persistent mutants of Salmonella enterica serovar typhimurium reveals a new toxin-antitoxin module. J. Bacteriol. 2013, 195, 647-657. [CrossRef]

417. Shan, Y.; Lazinski, D.; Rowe, S.; Camilli, A.; Lewis, K. Genetic basis of persister tolerance to aminoglycosides in Escherichia coli. MBio 2015, 6, e00078-15. [CrossRef]

418. McDermott, W. Microbial persistence. Yale J. Biol. Med. 1958, 30, 257-291.

419. Johnson, P.J.; Levin, B.R. Pharmacodynamics, population dynamics, and the evolution of persistence in Staphylococcus aureus. PLoS Genet. 2013, 9, e1003123. [CrossRef]

420. Chowdhury, N.; Kwan, B.W.; Wood, T.K. Persistence increases in the absence of the alarmone guanosine tetraphosphate by reducing cell growth. Sci. Rep. 2016, 6, 20519. [CrossRef] [PubMed]

421. Hong, S.H.; Wang, X.; O'Connor, H.F.; Benedik, M.J.; Wood, T.K. Bacterial persistence increases as environmental fitness decreases. Microb. Biotechnol. 2012, 5, 509-522. [CrossRef]

422. Lewis, K. Persister cells. Annu. Rev. Microbiol. 2010, 64, 357-372. [CrossRef]

423. Kaldalu, N.; Hauryliuk, V.; Tenson, T. Persisters-as elusive as ever. Appl. Microbiol. Biotechnol. 2016, 100, 6545-6553. [CrossRef]

424. Shan, Y.; Gandt, A.B.; Rowe, S.E.; Deisinger, J.P.; Conlon, B.P.; Lewis, K. ATP-dependent persister formation in Escherichia coli. MBio 2017, 8, e2267-16. [CrossRef]

425. Hobby, G.L.; Meyer, K.; Chaffee, E. Observations on the mechanism of action of penicillin. Exp. Biol. Med. 1942, 50, 281-285. [CrossRef]

426. Bigger, J.W. Treatment of staphylococcal infections with penicillin by intermittent sterilization. Lancet 1944, 244, 497-500. [CrossRef]

427. Van den Bergh, B.; Michiels, J.E.; Wenseleers, T.; Windels, E.M.; Boer, P.V.; Kestemont, D.; De Meester, L.; Verstrepen, K.J.; Verstraeten, N.; Fauvart, M.; et al. Frequency of antibiotic application drives rapid evolutionary adaptation of Escherichia coli persistence. Nat. Microbiol. 2016, 1, 16020. [CrossRef]

428. Cohen, N.R.; Lobritz, M.A.; Collins, J.J. Microbial persistence and the road to drug resistance. Cell Host Microb. 2013, 13, 632-642. [CrossRef] [PubMed] 
429. Levin-Reisman, I.; Ronin, I.; Gefen, O.; Braniss, I.; Shoresh, N.; Balaban, N.Q. Antibiotic tolerance facilitates the evolution of resistance. Science 2017, 355, 826-830. [CrossRef]

430. Shah, D.; Zhang, Z.; Khodursky, A.; Kaldalu, N.; Kurg, K.; Lewis, K. Persisters: A distinct physiological state of E. coli. BMC Microbiol. 2006, 6, 53. [CrossRef] [PubMed]

431. Lewis, K.; Shan, Y. Why tolerance invites resistance. Science 2017, 355, 796. [CrossRef] [PubMed]

432. Wiuff, C.; Andersson, D.I. Antibiotic treatment in vitro of phenotypically tolerant bacterial populations. J. Antimicrob. Chemother. 2007, 59, 254-263. [CrossRef]

433. Kwan, B.W.; Valenta, J.A.; Benedik, M.J.; Wood, T.K. Arrested protein synthesis increases persister-like cell formation. Antimicrob. Agents Chemother. 2013, 57, 1468-1473. [CrossRef]

434. Kwan, B.W.; Osbourne, D.O.; Hu, Y.; Benedik, M.J.; Wood, T.K. Phosphodiesterase DosP increases persistence by reducing CAMPwhich reduces the signal indole. Biotechnol. Bioeng. 2015, 112, 588-600. [CrossRef]

435. Lewis, K. Persister cells, dormancy and infectious disease. Nat. Rev. Microbiol. 2007, 5, 48-56. [CrossRef]

436. Lewis, K. Multidrug tolerance of biofilms and persister cells. In Bacterial Biofilms; Romeo, T., Ed.; Springer: Berlin/Heidelberg, Germany, 2008; Volume 322, pp. 107-131.

437. Vahdani, M.; Azimi, L.; Asghari, B.; Bazmi, F.; Lari, R.A. Phenotypic screening of extended-spectrum B-lactamase and metallo-ß-lactamase in multidrug-resistant Pseudomonas aeruginosa from infected burns. Annal. Burns Fire Disast. 2012, 25, 78-81.

438. Defraine, V.; Fauvart, M.; Michiels, J. Fighting bacterial persistence: Current and emerging anti-persister strategies and therapeutics. Drug Resist. Update 2018, 38, 12-26. [CrossRef]

439. Cabral, D.J.; Wurster, J.I.; Belenky, P. Antibiotic persistence as a metabolic adaptation: Stress, metabolism, the host, and new directions. Pharmaceuticals 2018, 11, 14. [CrossRef] [PubMed]

440. Ciofu, O.; Tolker-Nielsen, T. Tolerance and resistance of Pseudomonas aeruginosa biofilms to antimicrobial agents-how P. aeruginosa can escape antibiotics. Front. Microbiol. 2019, 10, 913. [CrossRef]

441. Yan, J.; Bassler, B.L. Surviving as a community: Antibiotic tolerance and persistence in bacterial biofilms. Cell Host Microbe. 2019, 26, 15-21. [CrossRef] [PubMed]

442. Pál, C.; Papp, B.; Lercher, M.J.; Gillings, M.R.; Paulsen, I.T.; Tetu, S.G. Genomics and the evolution of antibiotic resistance. Ann. N. Y. Acad. Sci. 2017, 1388, 92-107.

443. Fam, N.; Leflon-Guibout, V.; Fouad, S.; Aboul-Fadl, L.; Marcon, E.; Desouky, D.; El-Defrawy, I.; Abou-Aitta, A.; Klena, J.; Nicolas-Chanoine, M.H. CTX-M-15-producing clinical isolates in Cairo (Egypt), including isolates of clonal complex ST10 and clones ST131, ST73, and ST405 in both community and hospital settings. Microb. Drug Resist. 2011, 17, 67-73. [CrossRef] [PubMed]

444. Huang, J.; Lan, F.; Lu, Y.; Li, B. n Characterization of Integrons and Antimicrobial Resistance in Escherichia coli Sequence Type 131 Isolates. Can. J. Infect Dis. Med. Microbiol. 2020, 2020, 3826186. [CrossRef] [PubMed]

445. Gilmore, M.S.; Miller, O.K. A bacterium's enemy isn't your friend. Nature 2018, 563, 637-638. [CrossRef]

446. Kallonen, T.; Brodrick, H.J.; Harris, S.R.; Corander, J.; Brown, N.M.; Martin, V.; Peacock, S.J.; Parkhill, J. Systematic longitudinal survey of invasive Escherichia coli in England demonstrates a stable population structure only transiently disturbed by the emergence of ST131. Genome Res. 2017, 27, 1437-1449. [CrossRef]

447. McNally, A.; Kallonen, T.; Connor, C.; Abudahab, K.; Aanensen, D.M.; Horner, C.; Peacock, S.J.; Parkhill, J.; Croucher, N.J.; Corander, J. Diversification of colonization factors in a multidrug-resistant Escherichia coli lineage evolving under negative frequency-dependent selection. MBio 2019, 10, e00644-19. [CrossRef]

448. Mendes, R.E.; Bell, J.M.; Turnidge, J.D.; Castanheira, M.; Jones, R.N. Emergence and widespread dissemination of OXA-23, -24/40 and -58 carbapenemases among Acinetobacter spp. in Asia-Pacific nations: Report from the SENTRY Surveillance Program. J. Antimicrob. Chemother. 2009, 63, 55-59. [CrossRef]

449. Fridman, O.; Goldberg, A.; Balaban, N.Q. Whack an E. coli with the morbidostat. Genome Biol. 2012, $13,140$. [CrossRef] [PubMed]

450. Toprak, E.; Veres, A.; Yildiz, S.; Pedraza, J.M.; Chait, R.; Paulsson, J.; Kishony, R. Building a morbidostat: An automated continuous-culture device for studying bacterial drug resistance under dynamically sustained drug inhibition. Nat. Protoc. 2013, 8, 555-567. [CrossRef] [PubMed]

451. Liu, P.C.; Lee, Y.T.; Wang, C.Y.; Yang, Y.T. Design and use of a low cost, automated morbidostat for adaptive evolution of bacteria under antibiotic drug selection. J. Vis. Exp. 2016, 115, e54426. [CrossRef] [PubMed]

452. Nyerges, Á.; Csörgő, B.; Draskovits, G.; Kintses, B.; Szili, P.; Ferenc, G.; Révész, T.; Ari, E.; Nagy, I.; Bálint, B.; et al. Directed evolution of multiple genomic loci allows the prediction of antibiotic resistance. Proc. Natl. Acad. Sci. USA 2018, 115, 5726-5735. [CrossRef] [PubMed] 
453. Knöppel, A.; Knopp, M.; Albrecht, L.M.; Lundin, E.; Lustig, U.; Näsvall, J.; Andersson, D.I. Genetic adaptation to growth under laboratory conditions in Escherichia coli and Salmonella enteri. Front. Microbiol. 2018, 9, 756. [CrossRef] [PubMed]

454. Knöppel, A.; Näsvall, J.; Andersson, D.I. Evolution of antibiotic resistance without antibiotic exposure. Antimicrob. Agents. Chemother. 2017, 61, e01495-17. [CrossRef]

455. Toprak, E.; Veres, A.; Michel, J.B.; Chait, R.; Hartl, D.L.; Kishony, R. Evolutionary paths to antibiotic resistance under dynamically sustained drug selection. Nat. Genet. 2011, 44, 101-105. [CrossRef] [PubMed]

456. Dößelmann, B.; Willmann, M.; Steglich, M.; Bunk, B.; Nübel, U.; Peter, S.; Neher, R.A. Rapid and consistent evolution of colistin resistance in extensively drug-resistant Pseudomonas aeruginosa during morbidostat culture. Antimicrob. Agents Chemother. 2017, 61, e00043-17. [CrossRef]

457. Tan, K.; Nguyen, J.; Nguyen, K.; Huse, H.K.; Nieberg, P.H.; Wong-Beringer, A. Prevalence of the carbapenem-heteroresistant phenotype among ESBL-producing Escherichia coli and Klebsiella pneumoniae clinical isolates. J. Antimicrob. Chemother. 2020, 75, 1506-1512. [CrossRef] [PubMed]

458. Barlow, M.; Hall, B.G. Experimental prediction of the evolution of cefepime resistance from the CMY-2 AmpC beta-lactamase. Genetics 2003, 164, 23-29.

459. Barlow, M.; Hall, B.G. Experimental prediction of the natural evolution of antibiotic resistance. Genetics 2003, $163,1237-1241$.

460. Courpon-Claudinon, A.; Lefort, A.; Panhard, X.; Clermont, O.; Dornic, Q.; Fantin, B.; Mentré, F.; Wolff, M.; Denamur, E.; Branger, C. Bacteraemia caused by third-generation cephalosporin-resistant in France: Prevalence, molecular epidemiology and clinical features. Clin. Microbiol. Infect. 2011, 17, 557-565. [CrossRef] [PubMed]

461. MacLean, R.C.; Buckling, A. The distribution of fitness effects of beneficial mutations in Pseudomonas aeruginosa. PLoS Genet. 2009, 5, e1000406. [CrossRef] [PubMed]

462. Sousa, A.; Magalhães, S.; Gordo, I. Cost of antibiotic resistance and the geometry of adaptation. Mol. Biol. Evol. 2012, 29, 1417-1428. [CrossRef]

463. Storz, J.F. Compensatory mutations and epistasis for protein function. Curr. Opin. Struct. Biol. 2018, 50, 18-25. [CrossRef] [PubMed]

464. Chevereau, G.; Dravecka, M.; Batur, T.; Guvenek, A.; Ayhan, D.H.; Toprak, E.; Bollenbach, T. Quantifying the determinants of evolutionary dynamics leading to drug resistance. PLoS Biol. 2015, 13, e1002299. [CrossRef]

465. Lázár, V.; Singh, G.P.; Spohn, R.; Nagy, I.; Horváth, B.; Hrtyan, M.; Busa-Fekete, R.; Bogos, B.; Méhi, O.; Csörgő, B.; et al. Bacterial evolution of antibiotic hypersensitivity. Mol. Syst. Biol. 2013, 9, 700. [CrossRef]

466. Lázár, V.; Nagy, I.; Spohn, R.; Csörgő, B.; Györkei, Á.; Nyerges, Á.; Horváth, B.; Vörös, A.; Busa-Fekete, R.; Hrtyan, M.; et al. Genome-wide analysis captures the determinants of the antibiotic cross-resistance interaction network. Nat. Commun. 2014, 5, 4352. [CrossRef]

467. Pál, C.; Papp, B.; Lázár, V. Collateral sensitivity of antibiotic-resistant microbes. Trends Microbiol. 2015, 23, 401-407. [CrossRef] [PubMed]

468. Kintses, B.; Méhi, O.; Ari, E.; Számel, M.; Györkei, Á.; Jangir, P.K.; Nagy, I.; Pál, F.; Fekete, G.; Tengölics, R.; et al. Phylogenetic barriers to horizontal transfer of antimicrobial peptide resistance genes in the human gut microbiota. Nat. Microbiol. 2019, 4, 447-458. [CrossRef]

469. Dunai, A.; Spohn, R.; Farkas, Z.; Lázár, V.; Györkei, Á.; Apjok, G.; Boross, G.; Szappanos, B.; Grézal, G.; Faragó, A.; et al. Rapid decline of bacterial drug-resistance in an antibiotic-free environment through phenotypic reversion. Elife 2019, 8, e47088. [CrossRef]

470. Charretier, Y.; Diene, S.M.; Baud, D.; Chatellier, S.; Santiago-Allexant, E.; van Belkum, A.; Guigon, G.; Schrenzel, J. Colistin heteroresistance and involvement of the PmrAB regulatory system in Acinetobacter baumannii. Antimicrob Agents Chemother. 2018, 62, e00788-18. [CrossRef] [PubMed]

471. Apjok, G.; Boross, G.; Nyerges, Á.; Fekete, G.; Lázár, V.; Papp, B.; Pál, C.; Csörgő, B. Limited evolutionary conservation of the phenotypic effects of antibiotic resistance mutations. Mol. Biol. Evol. 2019, 36, 1601-1611. [CrossRef]

472. Kernéis, S.; Valade, S.; Woerther , P.L. Back into the wild: How resistant pathogens become susceptible again? Intensive Care Med. 2020, 46, 361-363. [CrossRef] [PubMed]

473. Horváth, P.; Barrangou, R. CRISPR/Cas, the immune system of bacteria and archaea. Science 2010, 327, 167-170. [CrossRef] [PubMed] 
474. Makarova, K.S.; Wolf, Y.I.; Iranzo, J.; Shmakov, S.A.; Alkhnbashi, O.S.; Brouns, S.J.J.; Charpentier, E.; Cheng, D.; Haft, D.H.; Horvath, P.; et al. Evolutionary classification of CRISPR-Cas systems: A burst of class 2 and derived variants. Nat. Rev. Microbiol. 2020, 18, 67-83. [CrossRef] [PubMed]

475. Pang, Z.; Raudonis, R.; Glick, B.R.; Lin, T.J.; Cheng, Z. Antibiotic resistance in Pseudomonas aeruginosa: Mechanisms and alternative therapeutic strategies. Biotechnol. Adv. 2019, 37, 177-192. [CrossRef] [PubMed]

476. Faure, E.; Kwong, K.; Nguyen, D. Pseudomonas aeruginosa in chronic lung infections: How to adapt within the host? Front. Immunol. 2018, 9, 2416. [CrossRef] [PubMed]

477. Mensa, J.; Barberán, J.; Soriano, A.; Llinares, P.; Marco, F.; Cantón, R.; Bou, G.; del Castillo, J.G.; Maseda, E.; Azanza, J.R.; et al. Antibiotic selection in the treatment of acute invasive infections by Pseudomonas aeruginosa: Guidelines by the Spanish Society of Chemotherapy. Rev. Esp. Quimioter 2018, 31, 78-100.

478. Falcone, G.; Garzelli, C.; Serra, M.C. Aspects of Pseudomonas aeruginosa opportunism. Giornale di batteriol. virol. ed immunol. 1979, 72, 62-71.

479. Koontz, C.S.; Chang, M.C.; Meredith, J.W. Effects of empiric antibiotic administration for suspected pneumonia on subsequent opportunistic pulmonary infections/ discussion. Am. Surg. 2000, 66, 1110.

480. Stover, C.K.; Pham, X.Q.; Erwin, A.L.; Mizoguchi, S.D.; Warrener, P.; Hickey, M.J.; Brinkman, F.S.L.; Hufnagle, W.O.; Kowalik, D.J.; Lagrou, M.; et al. Complete genome sequence of Pseudomonas aeruginosa PAO1, an opportunistic pathogen. Nature 2000, 406, 959-964. [CrossRef] [PubMed]

481. Gonzalez, M.R.; Ducret, V.; Leoni, S.; Perron, K. Pseudomonas aeruginosa zinc homeostasis: Key issues for an opportunistic pathogen. Biochim. Biophys. Acta. Gene Regul. Mech. 2019, 1862, 722-733. [CrossRef]

482. Azam, M.W.; Khan, A.U. Updates on the pathogenicity status of Pseudomonas aeruginosa. Drug Discov. 2019, 24, 350-359. [CrossRef] [PubMed]

483. Moradali, M.F.; Ghods, S.; Rehm, B.H. Pseudomonas aeruginosa lifestyle: A paradigm for adaptation, survival, and persistence. Front. Cell Infect. Microbiol. 2017, 7, 39. [CrossRef] [PubMed]

484. Baltrus, D.A.; Dougherty, K.; Diaz, B.; Murillo, R. Evolutionary Plasticity of AmrZ Regulation in Pseudomonas. mSphere 2018, 3, e00132-18. [CrossRef]

485. Brüggemann, H.; Migliorini, L.B.; Sales, R.O.D.; Koga, P.C.M.; Souza, A.V.D.; Jensen, A.; Poehlein, A.; Brzuszkiewicz, E.; Doi, A.M.; Pasternak, J.; et al. Comparative genomics of nonoutbreak Pseudomonas aeruginosa strains underlines genome plasticity and geographic relatedness of the global clone ST235. Genome Biol. Evol. 2018, 10, 1852-1857. [CrossRef] [PubMed]

486. Freschi, L.; Bertelli, C.; Jeukens, J.; Moore, M.P.; Kukavica-Ibrulj, I.; Emond-Rheault, J.G.; Hamel, J.; Fothergill, J.L.; Tucker, N.P.; McClean, S.; et al. Genomic characterization of an international Pseudomonas aeruginosa reference panel indicates that the two major groups draw upon distinct mobile gene pools. FEMS Microbiol. Lett. 2018, 365, 120. [CrossRef] [PubMed]

487. Watkins, S.C.; Sible, E.; Putonti, C. Pseudomonas PB1-Like Phages: Whole genomes from metagenomes offer insight into an abundant group of bacteriophages. Viruses 2018, 10, E331. [CrossRef] [PubMed]

488. Pachori, P.; Gothalwal, R.; Gandhi, P. Emergence of antibiotic resistance Pseudomonas aeruginosa in intensive care unit; a critical review. Genes Dis. 2019, 6, 109-119. [CrossRef] [PubMed]

489. Lupo, A.; Haenni, M.; Madec, J.Y. Antimicrobial resistance in Acinetobacter spp. and Pseudomonas spp. Microbiol. Spectr. Microbiol Spectr. 2018, 6, ARBA-0007-2017. [CrossRef]

490. Subedi, D.; Vijay, A.K.; Willcox, M. Overview of mechanisms of antibiotic resistance in Pseudomonas aeruginosa: An ocular perspective. Clin. Exp. Optom. 2018, 101, 162-171. [CrossRef] [PubMed]

491. Gaviard, C.; Jouenne, T.; Hardouin, J. Proteomics of Pseudomonas aeruginosa: The increasing role of post-translational modifications. Expert Rev. Proteom. 2018, 15, 757-772. [CrossRef] [PubMed]

492. Guitor, A.K.; Wright, G.D. Antimicrobial resistance and respiratory infections. Chest 2018, 154, $1202-1212$. [CrossRef]

493. Housseini, B.; Issa, K.; Phan, G.; Broutin, I. Functional mechanism of the efflux pumps transcription regulators from Pseudomonas aeruginosa based on 3D Structures. Front. Mol. Biosci. 2018, 5, 57. [CrossRef]

494. Jabalameli, F.; Taki, E.; Emaneini, M.; Beigverdi, R. Prevalence of metallo- $\beta$-lactamase-encoding genes among carbapenem-resistant Pseudomonas aeruginosa strains isolated from burn patients in Iran. Rev. Soc. Bras. Med. Trop. 2018, 51, 270-276. [CrossRef] [PubMed]

495. Nehme, D.; Li, X.Z.; Elliot, R.; Poole, K. Assembly of the MexAB-OprM multidrug efflux system of Pseudomonas aeruginosa: Identification and characterization of mutations in mexA compromising MexA multimerization and interaction with MexB. J. Bacteriol. 2004, 186, 2973-2983. [CrossRef] 
496. Wang, Y.; Venter, H.; Ma, S. Efflux pump inhibitors: A novel approach to combat efflux-mediated drug resistance in bacteria. Curr. Drug Targets 2016, 17, 702-719. [CrossRef]

497. Al-Wrafy, F.; Brzozowska, E.; Górska, S.; Gamian, A. Pathogenic factors of Pseudomonas aeruginosa-The role of biofilm in pathogenicity and as a target for phage therapy. Postepy High Med. Dosw. 2016, 71, 78-91. [CrossRef] [PubMed]

498. Mulcahy, L.R.; Isabella, V.M.; Lewis, K. Pseudomonas aeruginosa biofilms in disease. Microb. Ecol. 2014, 68, 1-12. [CrossRef] [PubMed]

499. Alav, I.; Sutton, J.M.; Rahman, K.M. Role of bacterial efflux pumps in biofilm formation. J. Antimicrob. Chemother. 2018, 73, 2003-2020. [CrossRef]

500. Grosso-Becerra, M.V.; Santos-Medellín, C.; González-Valdez, A.; Méndez, J.L.; Delgado, G.; Morales-Espinosa, R.; Servín-González, L.; Alcaraz, L.D.; Soberón-Chávez, G. Pseudomonas aeruginosa clinical and environmental isolates constitute a single population with high phenotypic diversity. BMC Genom. 2014, 15, 318. [CrossRef] [PubMed]

501. Jeukens, J.; Kukavica-Ibrulj, I.; Emond-Rheault, J.G.; Freschi, L.; Levesque, R.C. Comparative genomics of a drug-resistant Pseudomonas aeruginosa panel and the challenges of antimicrobial resistance prediction from genomes. FEMS Microbiol. Lett. 2017, 364, fnx161. [CrossRef] [PubMed]

502. Nordmann, P.; Ronco, E.; Naas, T.; Duport, C.; Michel-Briand, Y.; Labia, R. Characterization of a novel extended-spectrum beta-lactamase from Pseudomonas aeruginosa. Antimicrob. Agents Chemother. 1993, 37, 962-969. [CrossRef] [PubMed]

503. Dhar, S.; Kumari, H.; Balasubramanian, D.; Mathee, K. Cell-wall recycling and synthesis in Escherichia coli and Pseudomonas aeruginosa-Their role in the development of resistance. J. Med. Microbiol. 2018, 67, 1-21. [CrossRef]

504. Aeschlimann, J.R. The role of multidrug efflux pumps in the antibiotic resistance of Pseudomonas aeruginosa and other gram-negative bacteria: Insights from the Society of Infectious Diseases Pharmacists. Pharmacother. J. Human Pharmac. Drug Ther. 2003, 23, 916-924. [CrossRef]

505. Vila, J.; Martínez, J.L. Clinical impact of the over-expression of efflux pump in nonfermentative Gram-negative bacilli, development of efflux pump inhibitors. Curr. Drug Targets 2008, 9, 797-807. [CrossRef]

506. Fischer, N.; Raunest, M.; Schmidt, T.H.; Koch, D.C.; Kandt, C. Efflux pump-mediated antibiotics resistance: Insights from computational structural biology. Interdiscip. Sci. 2014, 6, 1-12. [CrossRef]

507. Puzari, M.; Chetia, P. RND efflux pump mediated antibiotic resistance in Gram-negative bacteria Escherichia coli and Pseudomonas aeruginosa: A major issue worldwide. World J. Microbiol. Biotechnol. 2017, 33, 24. [CrossRef]

508. Vahaboglu, H.; Coskunkan, F.; Tansel, O.; Ozturk, R.; Sahin, N.; Koksal, I.; Kocazeybek, B.; Tatman-Otkun, M.; Leblebicioglu, H.; Ozinel, M.A.; et al. Clinical importance of extended-spectrum beta-lactamase (PER-1-type)-producing Acinetobacter spp. and Pseudomonas aeruginosa strains. J. Med. Microbiol. 2001, 50, 642-645. [CrossRef]

509. Kidd, J.M.; Kuti, J.L.; Nicolau, D.P. Novel pharmacotherapy for the treatment of hospital-acquired and ventilator-associated pneumonia caused by resistant gram-negative bacteria. Expert Opin. Pharmacother. 2018, 19, 397-408. [CrossRef]

510. Szabó, D.; Szentandrássy, J.; Juhász, Z.S.; Katona, K.; Nagy, K.; Rókusz, L. Imported PER-1 producing Pseudomonas aeruginosa, PER-1 producing Acinetobacter baumannii and VIM-2-producing Pseudomonas aeruginosa strains in Hungary. Ann. Clin. Microbiol. Antimicrob. 2008, 7, 12. [CrossRef] [PubMed]

511. Lagacé-Wiens, P.R.S.; Adam, H.J.; Poutanen, S.; Baxter, M.R.; Denisuik, A.J.; Golden, A.R.; Nichol, K.A.; Walkty, A.; Karlowsky, J.A.; Mulvey, M.R.; et al. Trends in antimicrobial resistance over 10 years among key bacterial pathogens from Canadian hospitals: Results of the CANWARD study 2007-16. J. Antimicrob. Chemother. 2019, 74, iv22-iv31. [CrossRef] [PubMed]

512. Zhanel, G.G.; Golden, A.R.; Zelenitsky, S.; Wiebe, K.; Lawrence, C.K.; Adam, H.J.; Idowu, T.; Domalaon, R.; Schweizer, F.; Zhanel, M.A.; et al. Cefiderocol: A siderophore cephalosporin with activity against carbapenemresistant and multidrug-resistant gram-negative bacilli. Drugs 2019, 79, 271-289. [CrossRef] [PubMed]

513. Queenan, A.M.; Bush, K. Carbapenemases: The versatile beta-lactamases. Clin. Microbiol. Rev. 2007, 20, 440-458. [CrossRef]

514. Wozniak, T.M.; Barnsbee, L.; Lee, X.J.; Pacella, R.E. Using the best available data to estimate the cost of antimicrobial resistance: A systematic review. Antimicrob. Resist. Infect. Control 2019, 8, 26. [CrossRef] 
515. Hirakata, Y.; Srikumar, R.; Poole, K.; Gotoh, N.; Suematsu, T.; Kohno, S.; Kamihira, S.; Hancock, R.E.; Speert, D.P. Multidrug efflux systems play an important role in the invasiveness of Pseudomonas aeruginosa. J. Exp. Med. 2002, 196, 109-118. [CrossRef]

516. Nehme, D.; Poole, K. Interaction of the MexA and MexB components of the MexAB-OprM multidrug efflux system of Pseudomonas aeruginosa: Identification of MexA extragenic suppressors of a T578I mutation in MexB. Antimicrob. Agents Chemother. 2005, 49, 4375-4378. [CrossRef]

517. Jeukens, J.; Boyle, B.; Kukavica-Ibrulj, I.; Ouellet, M.M.; Aaron, S.D.; Charette, S.J.; Fothergill, J.L.; Tucker, N.P.; Winstanley, C.; Levesque, R.C. Comparative genomics of isolates of a Pseudomonas aeruginosa epidemic strain associated with chronic lung infections of cystic fibrosis patients. PLoS ONE 2014, 9, e87611. [CrossRef]

518. Martis, N.; Leroy, S.; Blanc, V. Colistin in multi-drug resistant Pseudomonas aeruginosa blood-stream infections: A narrative review for the clinician. J. Infect. 2014, 69, 1-12. [CrossRef]

519. Catry, B.; Cavaleri, M.; Baptiste, K.; Grave, K.; Grein, K.; Holm, A.; Jukes, H.; Liebana, E.; Navas, A.L.; Mackay, D.; et al. Use of colistin-containing products within the European Union and European Economic Area (EU/EEA): Development of resistance in animals and possible impact on human and animal health. J. Antimicrob. Agents. 2015, 46, 297-306. [CrossRef]

520. Hadadi-Fishani, M.; Khaledi, A.; Fatemi-Nasab, Z.S. Corelation between biofilm formation and antibiotic resistance in Pseudomonas aeruginosa: A meta-analysis. Infez. Med. 2020, 28, 47-54.

521. Valli, R.X.E.; Lyng, M.; Kirkpatrick, C.L. There Is No Hiding if You Seq: Recent breakthroughs in Pseudomonas aeruginosa Research Revealed by Genomic and Transcriptomic Next-Generation Sequencing. J. Med. Microbiol. 2020, 69, 162-175. [CrossRef] [PubMed]

522. Cao, H.; Lai, Y.; Bougouffa, S.; Zeling, X.Z.; Yan, A. Comparative genome and transcriptome analysis reveal distinctive surface characteristics and unique physiological potentials of Pseudomonas aeruginosa ATCC 27853. BMC Genom. 2017, 18, 459. [CrossRef] [PubMed]

523. Bianconi, I.; Jeukens, J.; Freschi, L.; Alcalá-Franco, B.; Facchini, M.; Boyle, B.; Molinaro, A.; Kukavica-Ibrulj, I.; Tümmler, B.; Levesque, R.C.; et al. Comparative genomics and biological characterization of sequential Pseudomonas aeruginosa isolates from persistent airways infection. BMC Genom. 2015, 16, 1105. [CrossRef] [PubMed]

524. Freschi, L.; Jeukens, J.; Kukavica-Ibrulj, I.; Boyle, B.; Dupont, M.J.; Laroche, J.; Larose, S.; Maaroufi, H.; Fothergill, J.L.; Moore, M.; et al. Clinical utilization of genomics data produced by the international Pseudomonas aeruginosa consortium. Front. Microbiol. 2015, 6, 1036. [CrossRef]

525. Cornforth, D.M.; Dees, J.L.; Ibberson, C.B.; Huse, H.K.; Mathiesen, I.H.; Kirketerp-Møller, K.; Wolcott, R.D.; Rumbaugh, K.P.; Bjarnsholt, T.; Whiteley, M. Pseudomonas aeruginosa transcriptome during human infection. Proc. Natl. Acad. Sci. USA 2018, 115, E5125-E5134. [CrossRef]

526. Kempf, M.; Rolain, J.M. Emergence of resistance to carbapenems in Acinetobacter baumannii in Europe: Clinical impact and therapeutic options. Int. J. Antimicrob. Agents 2012, 39, 105-114. [CrossRef]

527. Dubern, J.F.; Cigana, C.; De Simone, M.; Lazenby, J.; Juhas, M.; Schwager, S.; Bianconi, I.; Döring, G.; Eberl, L.; Williams, P.; et al. Integrated whole-genome screening for Pseudomonas aeruginosa virulence genes using multiple disease models reveals that pathogenicity is host specific. Environ. Microbiol. 2015, 17, 4379-4393. [CrossRef]

528. Beijerinck, M. Pigmenten als oxydatieproducten gevormd door bacterien. Versl. Koninklijke Akad. Wetensch. Amsterdam 1911, 19, 1092-1103.

529. Lessel, E.F. Subcommittee on nomenclature of Moraxella and allied bacteria. Int. J. Syst. Bacteriol. 1971, 21, 213-214. [CrossRef]

530. Lautrop, H. Bergey's Manual of Determinative Bacteriology; Williams \& Wilkins Co.: Baltimore, MD, USA, 1974.

531. Peleg, A.Y.; Seifert, H.; Paterson, D.L. Acinetobacter baumannii: Emergence of a successful pathogen. Clin. Microbiol. Rev. 2008, 21, 538-582. [CrossRef] [PubMed]

532. Bouvet, P.J.M.; Grimont, P.A.D. Taxonomy of the genus Acinetobacter with the recognition of Acinetobacter baumannii sp. nov., Acinetobacter haemolyticus sp. nov., Acinetobacter johnsonii sp. nov., and Acinetobacter junii sp. nov. and emended descriptions of Acinetobacter calcoaceticus and Acinetobacter lwoffii. Int. J. Syst. Evol. Microbiol. 1986, 36, 228-240.

533. Robenshtok, E.; Paul, M.; Leibovici, L.; Fraser, A.; Pitlik, S.; Ostfeld, I.; Samra, Z.; Perez, S.; Lev, B.; Weinberger, M. The significance of Acinetobacter baumannii bacteraemia compared with Klebsiella pneumoniae bacteraemia: Risk factors and outcomes. J. Hosp. Infect. 2006, 64, 282-287. [CrossRef] [PubMed] 
534. Antunes, L.C.S.; Visca, P.; Towner, K.J. Acinetobacter baumannii: Evolution of a global pathogen. Pathog. Dis. 2014, 71, 292-301. [CrossRef] [PubMed]

535. MarÝ-Almirall, M.; Cosgaya, C.; Higgins, P.G.; Van Assche, A.; Telli, M.; Huys, G.; Lievens, B.; Seifert, H.; Dijkshoorn, L.; Roca, I.; et al. MALDI-TOF/MS identification of species from the Acinetobacter baumannii (Ab) group revisited: Inclusion of the novel $A$. seifertii and A. dijkshoorniae species. Clin. Microbiol. Infect. 2017, 23, 210.e1-210.e9. [CrossRef] [PubMed]

536. Wareth, G.; Neubauer, H.; Sprague, L.D. Acinetobacter baumannii-A neglected pathogen in veterinary and environmental health in Germany. Vet. Res. Commun. 2019, 43, 1-6. [CrossRef]

537. Van der Kolk, J.H.; Endimiani, A.; Graubner, C.; Gerber, V.; Perreten, V. Acinetobacter in veterinary medicine, with an emphasis on Acinetobacter baumannii. J. Glob. Antimicrob. Resist. 2019, 16, 59-71. [CrossRef]

538. Peleg, A.Y.; de Breij, A.; Adams, M.D.; Cerqueira, G.M.; Mocali, S.; Galardini, M.; Nibbering, P.H.; Earl, A.M.; Ward, D.V.; Paterson, D.L.; et al. The success of Acinetobacter species; genetic, metabolic and virulence attributes. PLoS ONE 2012, 7, e46984. [CrossRef]

539. Zarrilli, R.; Pournaras, S.; Giannouli, M.; Tsakris, A. Global evolution of multidrug-resistant Acinetobacter baumannii clonal lineages. J. Antimicrob. Agents 2013, 41, 11-19. [CrossRef]

540. Lin, M.F.; Lan, C.Y. Antimicrobial resistance in Acinetobacter baumannii: From bench to bedside. World J. Clin. Cases 2014, 2, 787-814. [CrossRef]

541. Gales, A.C.; Seifert, H.; Gur, D.; Castanheira, M.; Jones, R.N.; Sader, H.S. Antimicrobial susceptibility of Acinetobacter calcoaceticus-Acinetobacter baumannii complex and Stenotrophomonas maltophilia clinical isolates: Results from the SENTRY antimicrobial surveillance program (1997-2016). Open Forum Infect. Dis. 2019, 6, S34-S46. [CrossRef] [PubMed]

542. Flamm, R.K.; Shortridge, D.; Castanheira, M.; Sader, H.S.; Pfaller, M.A. In Vitro Activity of Minocycline against U.S. Isolates of Acinetobacter baumannii-Acinetobacter calcoaceticus species complex, Stenotrophomonas maltophilia, and Burkholderia cepacia complex: Results from the SENTRY Antimicrobial Surveillance Program (2014-2018). Antimicrob Agents Chemother. 2019, 63, e01154-19. [PubMed]

543. Eichenberger, E.M.; Thaden, J.T. Epidemiology and mechanisms of resistance of extensively drug resistant gram-negative bacteria. Antibiotics 2019, 8, E37. [CrossRef] [PubMed]

544. Kochar, M.; Crosatti, M.; Harrison, E.M.; Rieck, B.; Chan, J.; Constantinidou, C.; Pallen, M.; Ou, H.Y.; Rajakumar, K. Deletion of TnAbaR23 results in both expected and unexpected antibiogram changes in a multidrug-resistant Acinetobacter baumannii strain. Antimicrob Agents Chemother. 2012, 56, 1845-1853. [CrossRef] [PubMed]

545. Rodríguez, C.H.; Nastro, M.; Famiglietti, A. Carbapenemases in Acinetobacter baumannii. Review of their dissemination in Latin America. Rev. Argent. Microbiol. 2018, 50, 327-333. [CrossRef] [PubMed]

546. Gniadek, T.J.; Carroll, K.C.; Simner, P.J. Carbapenem-resistant non-glucose-fermenting gram-negative Bacilli: The missing piece to the puzzle. J. Clin. Microbiol. 2016, 54, 1700-1710. [CrossRef]

547. Clark, N.M.; Zhanel, G.G.; Lynch, J.P. Emergence of antimicrobial resistance among Acinetobacter species: A global threat. Curr. Opin. Crit. Care 2016, 22, 491-499. [CrossRef]

548. Seiffert, S.N.; Perreten, H.M.V.; Endimiani, A. Extended spectrum cephalosporin resistant Gram-negative organisms in livestock: An emerging problem for human health. Drug Resist. Update 2013, 16, 22-45. [CrossRef]

549. Dijkshoorn, L.; Nemec, A.; Seifert, H. An increasing threat in hospitals: Multidrug resistant Acinetobacter baumannii. Nat. Rev. Microbiol. 2007, 5, 939-951. [CrossRef]

550. Chan, J.Z.; Halachev, M.R.; Loman, N.J.; Constantinidou, C.; Pallen, M.J. Defining bacterial species in the genomic era: Insights from the genus Acinetobacter. BMC Microbiol. 2012, 12, 302. [CrossRef]

551. Sahl, J.W.; Gillece, J.D.; Schupp, J.M.; Waddell, V.G.; Driebe, E.M.; Engelthaler, D.M.; Keim, P. Evolution of a pathogen: A comparative genomics analysis identifies a genetic pathway to pathogenesis in Acinetobacter. PLoS ONE 2013, 8, e54287. [CrossRef]

552. Vilacoba, E.; Almuzara, M.; Gulone, L.; Traglia, G.M.; Figueroa, S.A.; Sly, G.; Fernández, A.; Centrón, D.; Ramírez, M.S. Emergence and spread of plasmid-borne tet(B):ISCR2 in minocycline-resistant Acinetobacter baumannii isolates. Antimicrob. Agents Chemother. 2013, 57, 651-654. [CrossRef]

553. Vilacoba, E.; Déraspe, M.; Traglia, G.M.; Roy, P.H.; Ramírez, M.S.; Centrón, D. Draft genome sequence of an international clonal lineage 1 Acinetobacter baumannii strain from Argentina. Genome Announc. 2014, 2, e01190-14. [CrossRef] 
554. Aron, A.T.; Heffern, M.C.; Lonergan, Z.R.; Vander Wal, M.N.; Blank, B.R.; Spangler, B.; Zhang, Y.; Park, H.M.; Stahl, A.; Renslo, A.R.; et al. In vivo bioluminescence imaging of labile iron accumulation in a murine model of Acinetobacter baumannii infection. Proc. Natl. Acad. Sci. USA 2017, 114, 12669-12674. [CrossRef]

555. Post, V.; Hall, R.M. AbaR5, a large multiple-antibiotic resistance region found in Acinetobacter baumannii. Antimicrob. Agents Chemother. 2009, 53, 2667-2671. [CrossRef]

556. Farrugia, D.N.; Elbourne, L.D.; Hassan, K.A.; Eijkelkamp, B.A.; Tetu, S.G.; Brown, M.H.; Shah, B.S.; Peleg, A.Y.; Mabbutt, B.C.; Paulsen, I.T. The complete genome and phenome of a community-acquired Acinetobacter baumannii. PLoS ONE 2013, 8, e58628. [CrossRef]

557. Gallagher, L.A.; Lee, S.A.; Manoil, C. Importance of core genome functions for an extreme antibiotic resistance trait. MBio. 2017, 8, e01655-17. [CrossRef]

558. Karah, N.; Sundsfjord, A.; Towner, K.; Samuelsen, O. Insights into the global molecular epidemiology of carbapenem non susceptible clones of Acinetobacter baumannii. Drug Resist. Update 2012, 15, 237-247. [CrossRef]

559. Dhabaan, G.N.; AbuBakar, S.; Cerqueira, G.M.; Al-Haroni, M.; Pang, S.P.; Hassan, H. Imipenem treatment induces expression of important genes and phenotypes in a resistant Acinetobacter baumannii isolate. Antimicrob. Agents Chemother. 2015, 60, 1370-1376. [CrossRef]

560. Adams, M.D.; Goglin, K.; Molyneaux, N.; Hujer, K.M.; Lavender, H.; Jamison, J.J.; MacDonald, I.J.; Martin, K.M.; Russo, T.; Campagnari, A.A.; et al. Comparative genome sequence analysis of multidrug resistant Acinetobacter baumannii. J. Bacteriol. 2008, 190, 8053-8064. [CrossRef]

561. Hasani, A.; Sheikhalizadeh, V.; Ahangarzadeh Rezaee, M.; Rahmati-Yamchi, M.; Hasani, A.; Ghotaslou, R.; Goli, H.R. Frequency of aminoglycoside-modifying enzymes and ArmA among different sequence groups of Acinetobacter baumannii in Iran. Microb. Drug Resist. 2016, 22, 347-353. [CrossRef]

562. Caputo, A.; Fournier, P.E.; Raoult, D. Genome and pan-genome analysis to classify emerging bacteria. Biol. Direct 2019, 14, 5. [CrossRef]

563. Diancourt, L.; Passe, V.; Nemec, A.; Dijkshoorn, L.; Brisse, S. The population structure of Acinetobacter baumannii: Expanding multiresistant clones from an ancestral susceptible genetic pool. PLoS ONE 2010, 5, e10034. [CrossRef]

564. Zordan, S.; Prenger-Berninghoff, E.; Weiss, R.; van der Reijden, T.; van den Broek, P.; Baljer, G.; Dijkshoorn, L. Multidrug resistant Acinetobacter baumannii in veterinary clinics, Germany. Emerg. Infect. Dis. 2011, 17, 1751-1754. [CrossRef]

565. Joshi, S.G.; Litake, G.M. Acinetobacter baumannii: An emerging pathogenic threat to public health. World J. Clin. Infect. Dis. 2013, 3, 25-36. [CrossRef]

566. Repizo, G.D.; Viale, A.M.; Borges, V.; Cameranesi, M.M.; Taib, N.; Espariz, M.; Brochier-Armanet, C.; Gomes, J.P.; Salcedo, S.P. The environmental Acinetobacter baumannii isolate DSM30011 reveals clues into the preantibiotic era genome diversity, virulence potential, and niche range of a predominant nosocomial pathogen. Genome Biol. Evol. 2017, 9, 2292-2307. [CrossRef]

567. Vila, J.; Martı, S.; Sánchez-Céspedes, J. Porins, efflux pumps and multidrug resistance in Acinetobacter baumannii. J. Antimicrob. Chemother. 2007, 59, 1210-1215. [CrossRef]

(C) 2020 by the authors. Licensee MDPI, Basel, Switzerland. This article is an open access article distributed under the terms and conditions of the Creative Commons Attribution (CC BY) license (http://creativecommons.org/licenses/by/4.0/). 